\title{
Remembering the Civil Service:
}

Work and Life Stories of Indigenous Labourers in the Canadian Federal Civil Service

by

\section{Alisha Seguin}

A thesis submitted to the Faculty of Graduate Studies and Postdoctoral Affairs in partial fulfillment of the requirements

for the degree of

\author{
Master of Arts \\ in History
}

\author{
Carleton University \\ Ottawa, Ontario \\ (C) 2015
}




\begin{abstract}
This thesis examines the memories and experiences of six Indigenous civil servants who worked in the Canadian federal public service from the late 1960s until today. Special attention has been paid to the role of identity; these women and men mediated their cultural identities as Indigenous peoples with their economic identities as federal civil servants. To contextualize these lived experiences, this thesis also explores the development of a culture of merit, representation, and employment equity within the federal civil service in the mid to late twentieth century. As an oral history study, this thesis takes on a very personal note because each research partner narrates their stories of work within the frame of an entire life lived. This has allowed for an understanding of not only the perceptions of each narrator regarding the civil service as a place of employment, but also the role and meaning of this work within each individual life as a whole. As a result, this thesis argues that the complexity of individual experiences, identity formation, and memory makes it difficult to generalize about "the Indigenous civil servant" in any meaningful way. Relatedly, this thesis also emphasizes both the enriching possibilities and the unique challenges of conducting life story oral interviews and "sharing authority" in collaborative research projects.
\end{abstract}




\section{Acknowledgements}

I am very grateful to the faculty and staff in Carleton University's Department of History; they have been an invaluable source of support, both academically and administratively, as I have worked on this thesis. I owe a special thanks to my thesis supervisor, Dr. John C. Walsh, who guided me, pushed me, and provided me with many words of reassurance as I completed the challenging work of 'sharing authority' with my research partners. I also appreciate the comments and suggestions I received from thesis examiners: Dr. Hugh Shewell, Dr. Dominique Marshall, and Dr. Michel Hogue. I greatly value the patience and love I have received from my family and friends over the past two years as I immersed myself in this study. This project has also benefited from the helpful critique and suggestions of many Carleton student graduate historians, especially Marie-Anne Gagnon. The last word, however, must go to the Indigenous women and men who trusted me to share their stories with the public; I will always be in their debt. Aside from the snippets shared in the thesis itself, I have been granted permission by almost all of these research partners to archive the audio interviews and written interview transcripts within Archives and Research Collections (ARC) here at Carleton. In doing so, I hope these stories of struggle, accomplishment, and even survival will inspire others just as they have inspired me. 


\section{TABLE OF CONTENTS}

Page

Abstract

i

Acknowledgements

ii

Table of Contents

iii

List of Appendices

iv

Chapter One: Introduction

1

Chapter Two: Research Ethics, Subjectivity, and Collaboration

33

Chapter Three: Experiences and Memories of Indigenous Employees in the Canadian Federal Civil Service

Chapter Four: The Life Narrative(s) of Jaime Koebel 


\section{List of Appendices}

Research Ethics Clearance Form 163

$\begin{array}{ll}\text { Questions for Reflection } & 165\end{array}$ 


\section{Chapter One}

\section{Introduction}

In a 1965 article of The Indian News, a newspaper of the Indian Affairs branch of the Department of Citizenship and Immigration, Assistant Deputy Minister, R.F. Battle, encouraged Indigenous workers to enter into employment for the Canadian federal civil service: "I would like to see many more Indians enter the Civil Service...All Federal Departments are literally crying for trained personnel of many descriptions." ${ }^{11} \mathrm{He}$ added he did not feel, "[s]pecial treatment for Indians [would] improve the situation materially. Only steadfast dedication to regular education and training courses, together with a resolute determination to find and hold employment [would] bring the desired results." ${ }^{, 2}$ Such a remark revealed several aspects of Indian policy in mid-twentieth-century Canada. Firstly, the Canadian civil service wished to see a greater cultural diversity of Canadian workers in the bureaucracy, including Indigenous peoples. Secondly, Indian Affairs officials like Mr. Battle felt that too few Indigenous workers were qualified or had the work ethic and/or willingness to fulfill this demand. More broadly, however, such a passage speaks to larger shifts in Canadian society in the 1960s as Indigenous peoples began to leave reserves, some obtaining higher levels of education, and entering the wage economy in somewhat new sectors. ${ }^{3}$

\footnotetext{
1 "Indians serve their people on staff of Indian Affairs," Indian News 8, No. 2 (Ottawa: July 1965), 2.

${ }^{2}$ Ibid., 2.

${ }^{3}$ More information about this topic can be learned through the following texts: Karyn Pugliese, "So, where are you from? Glimpsing the History of Ottawa-Gatineau's Urban Indian Communities," Master's Thesis, Carleton University, 2005; Mary Jane Logan McCallum, Indigenous Women, Work, and History 1940-1980 (Winnipeg: University of Manitoba Press, 2013); Heather Howard-Bobiwash, "Women's Class Strategies as Activism in Native Community Building in Toronto, 1950-1975," The American Indian Quarterly Vol. 27, No. 3-4 (Summer/Fall 2003): 566-582; Nancy Janovicek, “Assisting Our Own: Urban Migration, Self-Governance, and Native Women's
} 
This thesis focuses on the work experiences and life stories of Indigenous civil servants in post-Second World War Ottawa. By 1986, there were 965 Indigenous workers in the federal public service. ${ }^{4}$ My ultimate research goal has been to conduct oral interviews documenting the work experiences of Aboriginal public servants who worked in Ottawa since the late 1960s. Through this research I have provided an avenue for several Indigenous civil servants to voice their experiences and identities within the historical record. ${ }^{5}$

My interviewees represent an interesting mosaic of identities, which reveals the variety of Indigenous peoples from across the country that came to work in the civil service. Interviewees have self-identified as members of many communities. An anonymous Odawa interviewee, who I henceforth refer to as John, has worked primarily for the Treasury Board Secretariat. ${ }^{6}$ Eric McGregor of Kitigan Zibi, has been a long time employee of Aboriginal Affairs and Northern Development Canada. Ronda Evans, from the North Temiskaming First Nation, worked as the former coordinator of Health Canada's Aboriginal Head Start program. Jaime Koebel, a former Educator of the National Gallery of Canada, has identified as a Métis woman with roots in the Albertan Kikino and Beaver Lake Métis communities. Lastly, Dave Monture, CQ, and Russ

Organizing in Thunder Bay, Ontario, 1972-1979," The American Indian Quarterly, Vol. 27, No. 3-4 (2003): 548565; Robin Jarvis Brownlie, "'Living the Same as the White People': Mohawk and Anishinabe Women's Labour in Southern Ontario, 1920-1940," Labour/ Le Travail Vol. 61 (Spring 2008) : 41-68; Julie Guard, “Authenticity on the Line: Women Workers, Native 'Scabs,' and the Multi-Ethnic Politics of Identity in a Left-led Strike in Cold War Canada," Journal of Women's History, Vol. 15, No. 4 (Winter 2004): 117-140; Joan Sangster, Transforming Labour: Women and Work in Postwar Canada (Toronto: University of Toronto Press, 2010).

${ }^{4}$ A Profile of the Aboriginal Population Residing in Selected Off-Reserve Areas, 1986 Census, Vol. I (Ottawa: Aboriginal and Native Issues Unit, Statistics Canada, 1990): Table 4.08.

${ }^{5}$ These life interviews will be archived at the close of the study within Archives and Research Collections (ARC) at Carleton University. It is my hope that these interviews will continue to serve as a resource for researchers and members of Aboriginal communities in the future.

${ }^{6}$ I offered anonymity to civil servants currently working for the federal government to mitigate risk to their careers and prevent job loss. Interview stories were still somewhat constrained. By examining Public Service Alliance Canada records discussing racial discrimination at work, researchers may learn more about racial tensions within the civil service than was possible to be obtained through life stories. 
Moses have worked in the Office of Native Employment, the Department of Canadian Heritage, and Aboriginal Affairs and Northern Development Canada. All three hail from the Six Nations of the Grand River Reserve near Brantford Ontario. These research participants have provided their personal experiences as members of these groups, but they do not represent their cultural communities when they relate their individual experiences as civil service employees.

Because Indigenous public servants were recruited from a wide range of reserves across Canada by the recommendation of recruitment officers and situated into positions within a government bureaucracy as we will see later, a number of social and cultural adaptations occurred. One of the key questions of this thesis has been to explore the shift that resulted as Indigenous civil servants mediated traditional cultural identities with their new social and economic identities prescribed by their work lives. I aim to understand how some post-war Indigenous peoples could both struggle for their status as citizens and also work for the federal state. In doing so, this thesis explores the formation and re-formation of personal identity throughout this process.

My second interest is the regulation of this workforce, which I have studied through both departmental records and also through interviews. What was the regulatory culture of bureaucracy within the civil service? Were interviewees conscious of their Aboriginality affecting their opportunities, salary, or job security? Lastly, how did these concepts change in their workplace experiences and career opportunities over time? Furthermore, I reflected on how the expansion of the public service led to a diversity of workers in the federal civil service, integrating minority groups so as to better reflect the demographic makeup of Canada as a whole.

This thesis is informed by oral history, feminist labour and working-class history, and critical histories of Indigenous work and Indigenous identity-making. Through oral history, as 
well as more traditional archival research in government departmental records and a secondary source literature review, I expect this study to contribute to the historiography of an understudied class of postwar urban Indigenous workers in Canadian history. ${ }^{7}$ In pursuing this research topic and in working collaboratively with my interviewees, I also intend this thesis to reflect the sensibilities and practices of intellectuals such as Steven High, Joan Sangster, Julie Cruikshank, and Craig Heron. ${ }^{8}$ In the chapters that follow, I explain the scholarly context of this thesis in more detail.

Much of this introductory chapter sketches the context within which Indigenous workers were enmeshed as they entered federal civil service employment in the mid to late twentieth century. This will be accomplished through the examination of two key themes: firstly, I will identify how Indigenous public servants were part of a much larger movement of urban

\footnotetext{
${ }^{7}$ I have chiefly been influenced by, among others, Alessandro Portelli, The Death of Luigi Trastulli, and Other Stories: Form and Meaning in Oral History (Albany, New York: State University of New York Press, 1991); Michael Frisch, A Shared Authority: Essays on the Craft and Meaning of Oral and Public History (Albany, New York: State University of New York Press, 1990; Steven High, "Native Wage Labour and Independent Production during the "Era of Irrelevance." Labour/ Le Travail Vol.37 (Spring 1996): 243-264; Steven High, "Sharing Authority: An Introduction," Journal of Canadian Studies Vol. 41, No. 1 (Winter 2009): 12-34; Stacey Zembrzycki, "Sharing Authority with Baba," The Journal of Canadian Studies Vol. 43, No. 1 (Winter 2009): 219-238; Joan Sangster, Transforming Labour: Women and Work in Postwar Canada (Toronto: University of Toronto Press, 2010); Hugh Shewell, 'Enough to Keep Them Alive:' Indian Welfare in Canada, 1873 -1965 (Toronto: University of Toronto Press, 2004); Keith Thor Carlson, The Power of Place, The Problem of Time: Aboriginal Identity and Historical Consciousness in the Cauldron of Colonialism, (Toronto: University of Toronto Press, 2010), John Sutton Lutz Makúk: A New History of Aboriginal White Relations (Vancouver: UBC Press, 2008); Craig Heron, The Canadian Labour Movement: A Short History (Toronto: James Lorimer, 1989; 2nd ed. 1996); Howard-Bobiwash, "Women's Class Strategies as Activism in Native Community Building"; Pugliese, "So, where are you from?"; Rosemary Elizabeth Warskett, "Learning to be 'Uncivil': Class Formation and Feminisation in the Public Service Alliance of Canada, 1966-1996," PHD Dissertation, Carleton University, 1998; and Julie Cruikshank, Life Lived Like a Story: Life Stories of Three Yukon Elders (Lincoln: University of Nebraska Press, 1990).

${ }^{8}$ In addition to High, "Sharing Authority," see also Steven High, "Native Wage Labour and Independent Production During the "Era of Irrelevance,"'Labour/ Le Travail Vol.37 (Spring 1996): 243-164; Joan Sangster, Transforming Labour: Women and Work in Post-War Canada (Toronto: University of Toronto Press, 2010); Julie Cruikshank, Life Lived Like a Story: Life Stories of Three Yukon Native Elders (Lincoln: University of Nebraska Press, 1990); and Craig Heron, "The Labour Historian and Public History," Labour/Le Travail Vol. 45 (Spring 2000), 171-97. I return to these issues later in the chapter.
} 
indigenous workers entering cities who subsequently carved both a space and a community for themselves. These individuals did not assimilate wholesale into the larger urban mainstream population, but instead negotiated their cultural identity with their identities as wage workers. I will ask how the regulatory culture of the civil service evolved in response to changes in liberal discourse and to the demographic composition of the civil service. The Public Service Commission (PSC) and the Treasury Board Secretariat (TBS) responded to these changes by pursuing the values of merit and representativeness through special recruitment programs, staffing policies and employment systems that realigned over time in accordance with new understandings of these values. Setting this context will provide a historical backdrop to the remainder of the thesis which has largely been grounded in the firsthand experiences and memories of Indigenous public servants who lived and worked during this time.

\section{Urban Indigeneity}

To understand these stories, however, the reader must recognize the racial discourse which enveloped Indigenous workers in early to mid-twentieth century Canada. Historian Steven High argues that Indigenous peoples were not seen to hold an important role within the new and developing capitalist wage economy in the twentieth century and therefore entered an "era of irrelevance." 9 This disempowering perspective evolved with the increasing stress placed on the liberal values of Canadian society, which promoted the principles of "property, individualism, and the virtues of work, science, and progress." ${ }^{\prime 10}$ Such principles were not new. J. R. Miller has argued that attempts to refashion Indigenous peoples into the dominant western culture began after the War of 1812 as threats to British control of Upper and Lower Canada were reduced and

\footnotetext{
${ }^{9}$ High, "Native Wage Labour."

${ }^{10}$ Hugh Shewell, 11.
} 
Indigenous peoples were no longer considered necessary allies. ${ }^{11}$ Assimilative policies were made possible by this shift. Day schools, industrial schools, and residential schools were subsequently introduced to direct the cultural change of Indigenous peoples. ${ }^{12}$

Moving to urban centres became an appealing option for Indigenous workers by the early twentieth century. According to Karyn Pugliese, hunting, trapping, and lumbering became unsustainable as a sole source of income for Indigenous communities living on reserves. Firstly the sale price of these goods reduced drastically in the early twentieth century and secondly less land was available for practicing these occupations. ${ }^{13}$ Living on reserves also meant the constant surveillance of Indian Agents who enforced the Indian Act. ${ }^{14}$ Such regulations could not be avoided even in cities, but at least the close scrutiny of Indian Agents would be lessened outside of reserves. ${ }^{15}$ Furthermore, the fact that the majority of Indigenous reserves were also laid out in the late nineteenth century, a period when disease had decimated many Indigenous communities, posed an obvious problem for Indigenous communities in the twentieth century when the numbers of Indigenous peoples in Canada grew from 100000 in 1934 to 200000 people in

\footnotetext{
${ }^{11}$ J. R. Miller, Skyscrapers Hide the Heavens (Toronto: University of Toronto Press, 1991), 87-93.

${ }^{12}$ J. R. Miller defines 'directed cultural change' as an outcome of settler colonists outnumbering Indigenous populations and consequently having the mandate to overpower Indigenous peoples, enculturating them into the dominant values of the majority. 'Directed cultural change' is opposed to 'non-directed cultural change' whereby Indigenous peoples who outnumber settler colonists have the ability to choose which elements of the dominant culture they consider worthy of borrowing, if any. Indigenous peoples make these changes voluntarily if they judge it to be desirable and in their own interests. See J. R. Miller, Skyscrapers Hide the Heavens, 95-96.

${ }^{13}$ Pugliese, "So, where are you from?"; also see the Department of Indian and Northern Affairs, Annual Report, 1902, xxi.

${ }^{14}$ Shewell discusses the effects of the 1876 and the later 1951 Indian Act. See Hugh Shewell, "Dreaming in Liberal White: Canadian Indian Policy, 1913-83," in Kristin Burnett and Geoff Read, eds., Aboriginal People: A History (Don Mills, Ontario: Oxford University Press, 2012), 171-175.

${ }^{15}$ Pugliese, 178-179.
} 
1964. ${ }^{16}$ The housing crisis which resulted from this population boom may have been partly responsible for the migrations of Indigenous workers into urban settings. ${ }^{17}$

Many Indigenous peoples also voluntarily moved to Canadian cities to pursue a higher level of education than would be available to them in their reserve communities where day schools and boarding schools only provided a basic education to the level of grade six. ${ }^{18}$ By 1957 , Indian Affairs supported the desires of Indigenous wards to receive an increased level of education by creating a standard application process for Indigenous students to obtain anywhere from five hundred to one thousand dollars each to supplement their studies. ${ }^{19}$ This education allowed Indigenous peoples to enter the urban white collar workforce. This was an important point of departure for Indigenous workers wishing to enter the civil service, as post-secondary education had become a prerequisite for entry into the Canadian federal civil service from the early to midtwentieth century. ${ }^{20}$

Indigenous peoples also began to carve space for themselves within a metropolitan context. Transitioning to an urban environment was not easy in this period, but structures of sociocultural support did form throughout many urban centres as the friendship centre movement began in the 1960s. By 1963, friendship centres were situated in Winnipeg, Vancouver and

\footnotetext{
${ }^{16}$ Pugliese, "So, where are you from?" 211; "Numbers Increase," Indian News Vol. 2, No. 4 (September 1957), 9; E.J. Dosman, Indians: The Urban Dilemma (Toronto: McLelland and Stewart, 1972), 21.

${ }^{17}$ Ibid.

${ }^{18}$ Karyn Pugliese, "So, where are you from?" 195-196.

${ }^{19}$ Pugliese, "So, where are you from?” 232-233; David S. Blanchard, Kahnawake: A Historical Sketch (Kahnawake: Kanien'kehaka Raotitiohkwa Cultural Centre, 1980), 10-12; "Indians to share valuable scholarships," The Indian News Vol. 2 No. 3 (March 1957), 1.

${ }^{20}$ Pugliese, "So, where are you from?" 222; J. L. Granatstein, The Ottawa Men: the Civil Service Mandarins, 1935 1957 (Toronto: Oxford University Press, 1982), 20.
} 
Toronto. ${ }^{21}$ The Indian News encouraged "out-of-town visitors to notify Friendship Centres of their impending arrival and what, if any, assistance they [required]. ${ }^{22}$ New urban arrivals were also asked "to consult their chiefs, Indian superintendents, teachers, or employment services regarding job prospects and accommodation before leaving home to seek work in strange cities." ${ }^{23}$ By 1963, the Canadian Indian Centre of Toronto was said to support about 4000 urban Indigenous clients with educational and employment referrals, through a subsidized recreational program that included a gymnasium and other athletic facilities, and also through community building initiatives and programs. ${ }^{24}$ Early friendship centres communicated with one another via national conferences in the 1960s and the National Association of Friendship Centres was born in 1972 to oversee a common mandate and purpose for these services. ${ }^{25}$ The population was much smaller in Ottawa. By the 1961 census, however, 180 Indigenous individuals were identified as living in the capital city. ${ }^{26}$ The Odawa Native Friendship Centre opened in August 1975 to serve Ottawa's urban Indigenous population. ${ }^{27}$

Among those who lived in Ottawa were some Indigenous peoples who found work in the civil service. In 1965, Miss Joan Lois Thom, Mrs. H. Dempsey, and Miss Agnes Young were

\footnotetext{
${ }^{21}$ Allison M. Williams, "Canadian Urban Aboriginals: A Focus on Aboriginal Women in Toronto," The Canadian Journal of Native Studies, Vol. 17, No. 1 (1997), 85.

22 "Friendship Centres and Clubs Make Indians Feel at Home," Indian News Vol. 7, No. 1 (Ottawa: December 1963), 1.

${ }^{23}$ Ibid.

${ }^{24}$ Ibid., 1.

${ }^{25}$ National Association of Friendship Centres, “About the NAFC,” Date Accessed: 20 February 2015: http://nafc.ca/about/.

${ }^{26}$ Pugliese, “So, where are you from?” 232.

${ }^{27}$ Odawa Native Friendship Centre, "Home," Date Accessed: 20 February 2015: http://www.odawa.on.ca/home.html.
} 
highlighted in The Indian News for their work as minute takers for Indian Affairs: "The fact that these Indians were chosen to act as secretaries of these important meetings is indicative of their value to the Indian Affairs Branch and symbolic of the way in which persons of their race are achieving success in the business world. ${ }^{, 28}$ In this way, the department set the example by hiring Indigenous workers, providing job experience, and advertising the success of this strategy publically to the rest of Canadians. After all, this was originally why many Indigenous civil servants were hired into the civil service. Karyn Pugliese also documents how a small number of Indigenous civil servants worked in Ottawa as clerks, stenographers, and publication editors. For the most part, however, she finds these were lesser paid and lower placed positions within the hierarchy of the civil service. ${ }^{29}$ Mary Jane Logan McCallum has similarly found the federal government promoted stable and ongoing wage work as an avenue for the social and economic integration of Indigenous workers, while also doing very little to ameliorate the fact that Indigenous workers found themselves restricted to lower paid positions. ${ }^{30}$

In 1957, the Indian Affairs branch of the Department of Citizenship and Immigration created an employment placement programme to encourage young Indigenous workers to enter wage work throughout Canada; it became known as the Indian Placement and Relocation Programme. ${ }^{31}$ While it sought to expand opportunities for Indigenous workers, Mary Jane Logan McCallum argues that we should understand this initiative as a continuing appendage of

\footnotetext{
28 "Indian Girls Record Conference Minutes," The Indian News Vol. 1, No. 4 (Ottawa: July 1955), 7; The Indian News was a departmental newspaper published by the Department of Indian and Northern Affairs from 1954-1974.

${ }^{29}$ Pugliese, "So, where are you from?" 242-243.

${ }^{30}$ Mary Jane Logan McCallum, Indigenous Women, Work, and History 1940-1980 (Winnipeg: University of Manitoba Press, 2014), 77.

${ }^{31}$ Department of Citizenship and Immigration, Annual Report of Indian Affairs Branch, 1960, 46-47.
} 
Canadian colonialism. ${ }^{32}$ Indeed, Deputy Minister R. F. Battle encouraged the civil service to more broadly hire Indigenous peoples so that integration into Canadian society would be permanent. Government officials feared the opposite, of course, that Indigenous workers might 'regress' if they returned to their reserve communities. ${ }^{33}$ Originally, three placement officers were located in the main urban centres of Vancouver, Edmonton, and Toronto in 1957, but soon spread across the country. ${ }^{34}$ Their preference was to recruit post-secondary graduates. ${ }^{35}$ Successful candidates were then placed into work positions with the help of the National Employment Service. Placement officers also sought out housing and temporary loans for placement candidates to ensure a smoother transition. ${ }^{36}$ By 1960, the Indian Affairs branch created an Economic Development Division to oversee this new program. ${ }^{37}$ The branch boasted 231 successful placements in permanent positions by 1959 and 1500 individuals by $1963 .{ }^{38}$ The Indian Affairs branch itself was a possible employer for qualified candidates and claimed the employment of 52 full time staff and 200 seasonal Indigenous staff in their 1960 Annual Report. $^{39}$

\footnotetext{
${ }^{32}$ McCallum, Indigenous Women, Work, and History 1940-1980: 66-119.

${ }^{33}$ Pugliese, "So, where are you from?" 241-242; Library and Archives Canada [hereafter LAC], RG10 v 8424 file 1/21-3 pt. 1 November 10th 1960 R.F. Battle to Director of Personnel Chief Economic Division.

34 "Employment Horizon Broadens for Indians: New placement service aids jobhunters," Indian News Vol. 2, No. 4 September 1957), 2; There were seventeen placement officers working busily in Canadian cities by 1963. See "Some 1,500 Find Jobs: Placement Program Successful," Indian News Vol. 6, No. 3 (Ottawa: February 1963), 3.

35 "Employment Horizon Broadens for Indians: New placement service aids jobhunters," Indian News Vol. 2, No. 4 (September 1957), 2.

${ }^{36}$ Ibid., 2.

${ }^{37}$ Department of Citizenship and Immigration, Annual Report of Indian Affairs Branch, 1960, 46.

${ }^{38}$ Ibid., 47; "Some 1,500 Find Jobs: Placement Program Successful," Indian News Vol. 6, No. 3 (Ottawa: February 1963), 3 .

${ }^{39}$ Department of Citizenship and Immigration, Annual Report of Indian Affairs Branch, 1960, 82.
} 
The federal government did not have the funds to oversee this transition entirely, however. The National Association of Friendship Centres struggled financially as they attempted to accommodate the needs of incoming migrants to Canadian cities within an environment of limited government funding. ${ }^{40}$ The impact of this underfunding was severe. Despite some modest successes in the Placement program, a large proportion of Indigenous migrants to cities were not pre-selected candidates for urban integration. They came of their own volition to create lives and communities of their own in urban cities, and turned to friendship centres for support in their transition. The centres struggled financially to meet the demand for their services.

Still, a new group of Indigenous middle class workers became visible in Canadian cities. For example, in 1972, sociologist Edgar Dosman identified the formation of an Indigenous middle class in Saskatoon as being primarily identified with a firm Indigenous identity, long term employment, and stable homes. ${ }^{41}$ Heather Howard-Bobiwash asserts that this urban Indigenous middle class did not necessarily fit into the linear trajectory of Indigenous assimilation into the dominant Euro-American culture. Instead, they formed in a horizontal fashion as Indigenous peoples cleared a new place for themselves in relation to the dominant culture, society, and economy, without reneging on their Indigenous identities. ${ }^{42}$ This was certainly true in Toronto, where Indigenous women and men banded together to create a positive image of Indigenous identity within the city and to develop community organizations to better sustain their cultural

\footnotetext{
${ }^{40}$ Cliff Gazee,"Future of Urban Natives Discussed," The Native Perspective Vol. 2 No. 1 (December 1976), 34.

${ }^{41}$ Howard-Bobiwash, "Women's Class Strategies as Activism in Native Community Building in Toronto," 570; E.J. Dosman, Indians: The Urban Dilemma (Toronto: McClelland and Stewart, 1972), 48-56.

${ }^{42}$ Howard-Bobiwash, "Women's Class Strategies as Activism in Native Community Building in Toronto," 571; Howard-Bobiwash builds her analysis off Sherry Ortner's model of "relational integration". See Sherry Ortner, "Reading America: Preliminary Notes on Class and Culture," in Recapturing Anthropology: Working in the Present, edited by Richard Fox (Santa Fe NM: School of American Research Press, 1991), 172.
} 
life. $^{43}$ The North American Indian Club was founded in Toronto in 1950, and this was followed by the Native Centre's Auxiliary in $1963 .{ }^{44}$ Club members worked closely with upper class white women from the Imperial Order of the Daughters of the Empire to fundraise for and open the Native Canadian Centre in Toronto. ${ }^{45}$ These early Indigenous migrants to Toronto were consequently able to navigate the social circles of the city to establish and fund the cultural space that became known as the Native Canadian Centre. Here, they tapped into a circle of social support, found lodgings with people of similar backgrounds, and practiced traditional craft making and dance. ${ }^{46}$ Indigenous newcomers to the city were assisted culturally as they transitioned from reserves into the city. This transition was on their own terms, in a social space they created for themselves within the city. Consequently, instead of being integrated into Canadian mainstream society through their work as wished by INAC, a new community of urban indigeneity was created.

Karyn Pugliese has similarly looked at the creation of an urban Indigenous community in Ottawa. She finds that early Indigenous migrants to the city often came to live near kin who had already moved to the city. ${ }^{47}$ A native friendship centre was not established until the 1970 s in Ottawa. Instead, she argues, Indigenous people forged a community through their association with the Indian Affairs Department through their pursuit of social and cultural activities with

\footnotetext{
${ }^{43}$ Howard-Bobiwash, "Women's Class Strategies as Activism in Native Community Building in Toronto," 567.

${ }^{44}$ Heather Howard-Bobiwash, 572-574.

${ }^{45}$ Pugliese, "So, where are you from?" 272-277; David Monture, "Profile of a Friendship Centre," Indian News, Vol. 12, No. 7 (Ottawa: October 1969), 5.

${ }^{46}$ Pugliese, "So, where are you from?" 271.

${ }^{47}$ Ibid, 220.
} 
fellow staff members outside of work. ${ }^{48}$ Pugliese observed Indigenous civil servants to have a great deal in common as educated youth in search of urban employment, who ended up working for the civil service, and who formed a sense of urban community through their creation of clubs and societies. $^{49}$ In addition to the opening of the Odawa Native Friendship Centre in 1975, these included the restoration of the annual inter-tribal powwow for urban Indigenous peoples in the Ottawa and Gatineau area in 1977.

\section{Merit and Representativeness}

From the mid twentieth century onward, attitudes towards Indigenous workers and employees from other minority groups began to be challenged and redefined. J. R. Miller has examined Indigenous agency and resistance in the twentieth-century Canadian political and economic climate. Miller argues that until the 1970s assumptions regarding Indigenous ability to participate in the development of Canadian politics were underestimated due to the lingering discourse of colonialism. ${ }^{50}$ By the end of the Second World War, many Canadians began to question the policy regarding First Nation peoples. ${ }^{51}$ Among other things, Indigenous peoples had once again volunteered in large numbers to serve in the Canadian forces, generating a positive social image within Canada.

The election of Pierre Elliott Trudeau in 1968 was thought to be the beginning of a more just and equal treatment of subaltern groups within Canada. Unfortunately, Trudeau's beliefs in individual rights did not originally extend to an understanding of the rights of collective groups

\footnotetext{
${ }^{48}$ Ibid., 232.

${ }^{49}$ Pugliese, "So, where are you from?" 19.

${ }^{50}$ Miller, Skyscrapers Hide the Heavens, 214; or Hugh Shewell, Enough to Keep them Alive.

${ }^{51}$ Ibid., 220.
} 
within Canada. ${ }^{52}$ As a result, the White Paper policy of 1969 further disenchanted Indigenous activists in regard to the potential for change. Miller consequently traces the real root of contemporary Indigenous politicization to the universal disdain of White Paper policy in Canada. ${ }^{53}$ Some of this disdain was expressed by the National Indian Brotherhood and then after 1982 by the newly-named Assembly of First Nations. Now, in addition to having a strong sense of community and identity within cities and reserves, Indigenous peoples also had larger political organizations to further their interests. One concern of these organizations was the makeup of the Canadian federal civil service.

A restructuring of civil service staffing policies, one that made gestures towards a new cultural sensitivity, slowly emerged in the 1950s and thereafter. Before this period, the Canadian civil service was largely the employer of white settler male, English-speaking employees. ${ }^{54} \mathrm{Jack}$ Granatstein suggests a new diversity, especially for French Canadians, was created by the late 1950s. Also a new generation of experts and staff of various disciplinary backgrounds began to help advise political leaders. ${ }^{55}$ Below this elite level of the bureaucracy, the expansion of government in these years also created new opportunities for women and marginalized groups to enter previously restricted positions.

Two departments have historically influenced the staffing of the Canadian federal public service. Since 1908, the Public Service Commission (PSC), previously known as the Civil Service Commission, has overseen all hiring within the civil service including the

\footnotetext{
${ }^{52}$ Ibid., 224.

${ }^{53}$ Ibid., 232.

${ }^{54}$ J. L. Granatstein, The Ottawa Men: The Civil Service Mandarins, 1935-1957 (Toronto: Oxford University press, 1982).

${ }^{55}$ Ibid., 279.
} 
implementation of practices and policies buttressing the merit principle for hiring and promotion (rather than the "old" practices of patronage and nepotism). ${ }^{56}$ In the 1970 s, the Public Service Commission began to re-examine their hiring rationales, policies, and employment systems for potential discrimination. In their Annual Report for 1971, the Public Service Commission recognized that women and Indigenous peoples were excluded from full participation in employment within the civil service. ${ }^{57}$ The PSC had consequently become conscious of the limitations of the merit principle, or at least made more explicit their awareness of the inequality being afforded certain groups of workers. Their response was to redefine this value by creating special recruitment programs that would increase the representativeness of disadvantaged groups within the country. Their guiding questions in pursuing a new policy became the following: "Is a public service that does not fully represent the people it serves the best possible public service? And if not, how can we ensure that there is true equality of opportunity for all peoples when it comes to being considered for appointment or promotion in the public service?",58 In doing so, the PSC required the support and co-operation of the Treasury Board Secretariat (TBS), which was created in 1951 to manage the financial planning of the civil service and to set central policies for staffing within the civil service. ${ }^{59}$ The Treasury Board Secretariat approved and

\footnotetext{
${ }^{56}$ Luc Juillet and Ken Rasmussen, Defending a Contested Ideal: Merit and the PSC of Canada, 1908-2008 (Ottawa: University of Ottawa Press, 2008), 50.

${ }^{57}$ Public Service Commission, Annual Report, 1971.

${ }^{58}$ Ibid.

${ }^{59}$ Rosemary Elizabeth Warskett, "Learning to be 'Uncivil': Class Formation and Feminisation in the Public Service Alliance of Canada, 1966-1996," PHD Dissertation, Department of Sociology and Anthropology, Carleton University, 1998, 145.
} 
funded many of the initiatives administered by the Public Service Commission which made a more equitable civil service possible. ${ }^{60}$

The impetus for updating the merit principle was the challenge posed by women addressing gender inequalities in the Canadian federal civil service in the late 1960s and early 1970s, and a key impetus was the 1967 Royal Commission on the Status of Women. ${ }^{61}$ The results of this commission were released in 1970 and women were recognized to be both financially and occupationally segregated within Canada ${ }^{62}$ At the same time, the PSC and TBS hired Dr. Kathleen Archibald to complete a social science study of the federal public service as an employer; the result was released in a 1969 report titled, "Sex and the Public Service."”3 Archibald confirmed that women in 1967 were confined to entry level positions within the civil service. Furthermore, only ten percent of these women received a salary of over six thousand dollars for their work. In 1967, the Public Service Employment Act was modified to include sex as a category for non-discrimination in the merit principle. ${ }^{64}$ The Office for Equal Opportunities for Women was also instituted to oversee this new direction. ${ }^{65}$ Rosemary Warskett argues, however, that gender inequalities continued to exist right up to the 1990s, pointing out that the Public Service Alliance of Canada's strike of 1991 was a result of the discrepancy in pay equity

\footnotetext{
${ }^{60}$ Public Service Commission of Canada, "History of Employment Equity in the Public Service and the Public Service Commission of Canada," Equity and Diversity Directorate. Released October 2011. Last Modified 25 October 2011: http://www.psc-cfp.gc.ca/plcy-pltq/eead-eeed/rprt/ee-psc-cfp/index-eng.htm, 21, 34.

${ }^{61}$ Public Service Commission of Canada, Annual Report, 1973, 44.

${ }^{62}$ Warskett, "Learning to be 'Uncivil': Class Formation and Feminisation in the Public Service Alliance of Canada, 1966-1996," 267.

${ }^{63}$ Public Service Commission of Canada, Annual Report, 1969, 44.

${ }^{64}$ Ibid., 44.

${ }^{65}$ Public Service Commission of Canada, Annual Report, 1970, 52; Public Service Commission of Canada, Annual Report, 1973, 6.
} 
between male and female employees ${ }^{66}$ Still, it was concerns about gender and workplace equity in the 1970s, however, that successfully opened debates about the inadequacy of staffing policies that might cause the marginalization of other groups in the civil service.

The federal government turned its attention to Indigenous employment within the civil service soon after acknowledging the existence of gender discrimination. In 1968, the Indian Eskimo Recruitment Development Program was instituted within the Department of Indian and Northern Affairs to increase access to middle management positions in the civil service for Indigenous public servants. ${ }^{67}$ In 1971, the Native Employment Program was established with a mandate to seek increased opportunities for Indigenous workers within the civil service through the collaboration of both federal government departments and Indigenous organizations. ${ }^{68} \mathrm{In}$ 1972, an Anti-Discrimination branch was created within the larger Public Service Commission and employees began to have what was promised to be a safe and structured outlet for reporting their workplace grievances. ${ }^{69}$ The federal government also hired Indigenous human rights officers to work in this branch. ${ }^{70}$

The Office of Native Employment (ONE) was instituted in 1973 with a more defined mandate to encourage and refer qualified Indigenous workers, especially graduates of postsecondary institutions, into the civil service. ONE was also responsible for research into the

\footnotetext{
${ }^{66}$ Warskett, "Learning to be 'Uncivil Class Formation and Feminisation in the Public Service Alliance of Canada 1966-1996," 5-10.

${ }^{67}$ Department of Indian Affairs and Northern Development, Annual Report, (Ottawa: 1968-1969).

${ }^{68}$ Public Service Commission of Canada, Annual Report, 1972.

${ }^{69}$ Ibid.

${ }^{70}$ Dave Monture, “An Indian in Ottawa," The Indian News Vol. 12, No. 9 (Ottawa: December 1969), 7. Note that this is the same Dave Monture whom I interviewed and whose stories we will hear later in this thesis.
} 
"needs" of the increasing population of Indigenous public servants. ${ }^{71}$ Collaborative workshops were held by ONE in the 1970s and various employment issues and corresponding solutions were considered on varied topics: such as more carefully explaining civil service application requirements to Indigenous applicants, bearing in mind underlying reasons why Indigenous workers might object to working for the federal government; investigating employment policies like bilingualism which might prevent Indigenous recruits from being interviewed; and observing how few high level positions existed for Indigenous employees within the civil service. $^{72}$

In 1978, a new Indigenous employment policy was released through the collaboration of the Treasury Board Secretariat, the Public Service Commission, and Indigenous communities in Canada. The "Policy to Increase the Participation of Indigenous People in the Public Service" had several caveats. ${ }^{73}$ First, it demanded that Indigenous workers be considered for civil service employment, especially within job descriptions that would specifically serve Indigenous communities. Furthermore, cultural sensitivity training was to be introduced for employees of the civil service. Policy makers, moreover, acknowledged the necessity to further research the needs of Indigenous employees and more equitable staffing and hiring procedures. ${ }^{74}$ This policy would be actively enforced and overseen by a joint council made of up representatives of the PSC, TBS, and the Presidents of both the Native Women's Association of Canada and the National

\footnotetext{
${ }^{71}$ Public Service Commission of Canada, Annual Report, 1973.

${ }^{72}$ Melissa Lazore, "Natives and the Public Service Commission," The Native Perspective Vol. 2 No. 4 (1977), 22.

${ }^{73}$ I will return to further discuss this policy in Chapter Three in relation to one of the interviewees of the study. Dave Monture was involved in the creation of this radical new method of approaching the employment of Indigenous peoples within the federal government.

74 “POLICY ANNOUNCED TO INCREASE NATIVE JOB OPPORTUNITIES IN THE PUBLIC SERVICE," The Native Perspective. Vol. 3 No. 2 (1978), 13-14.
} 
Association of Friendship Centres. ${ }^{75}$ In 1975, the Office of Native Employment further encouraged Indigenous employment through the launching of the Northern Careers Program. By 1981, the Public Service Commission celebrated its training of fifty-eight Indigenous employees for middle and senior civil service positions in Northern Canada through the Northern Careers Program. ${ }^{76}$

By the early 1980s, the federal government considered earlier measures to meaningfully diversify Indigenous employment in the civil service to have failed. Such insights partly came through the agitation of outside agencies which called on the civil service to provide better results on the issue of employment equity. For example, the Canadian Ethnocultural Council (CEC) penned a scathing report in 1988 which demanded a more representative civil service for Canada as a condition for equality. ${ }^{77}$ They titled their report "On the Sidelines of her Majesty's Service: A Survey of Employment Equity for Visible Minorities in the Federal Public Service." Through statistics from 1988, the CEC found that $2.9 \%$, or 6049 employees in the civil service, were visible minorities. This was considered unacceptable as the civil service employed more than 200000 employees. Furthermore, the CEC claimed the availability rate for visible minorities in the larger Canadian workforce was $6.4 \%$, meaning the civil service was only attracting less than half of what was available. The CEC commended the creation of the Employment Equity Act within Canada for the private sector and for government crown corporations but asked that the civil service might also be required to conform to the act as well. Furthermore, the CEC called upon the Treasury Board to become responsible for the

\footnotetext{
${ }^{75}$ Public Service Commission, Annual Report, Vol. 1, 1980, 15.

${ }^{76}$ Public Service Commission, Annual Report, 1981, 21-22.

77 The Canadian Ethnocultural Council was formed in 1980 to address cultural inequalities in Canada. They represent a cross section of ethnocultural groups within Canada, including Indigenous peoples. Canadian Ethnocultural Council, “About,” Date Accessed 12 May 2015: http://www.ethnocultural.ca/.
} 
representation of minority groups throughout the civil service. ${ }^{78}$ Consequently, watch dogs such as the $\mathrm{CEC}$ helped to catalyze government reforms regarding employment equity by conducting its own research on employment equity, developing recommendations for improvement, and presenting these findings to the federal government.

In part, domestic scrutiny in Canada may have come from investigations by the United Nations in regard to the status and treatment of Canadian Indigenous peoples. Indigenous political organizations such as the National Indian Brotherhood, Inuit Tapirisat of Canada, and the Native Council of Canada, began meeting with United Nation representatives as part of a global study on the Prevention of Discrimination and Protection of Minorities conducted between 1972 and $1977 .{ }^{79}$ A second major United Nations study occurred in 1990 and Elizabeth Evatt of the Committee on the Elimination of Discrimination Against Women prompted Canada to explain the position of Indigenous women in Canada. In particular, the Government of Canada was asked to speak to the rights, freedoms, economic opportunities, and pay equity of Indigenous women. Similarly, the United Nations requested an update on programming designed to further these equality initiatives within the country. Canada responded to increasing international pressure to counter racial discrimination by establishing 10 March 1988 as Human Rights Day, by increasing human rights education through the Department of Multiculturalism and Citizenship Canada, and by passing the Canadian Multiculturalism Act also in 1988. In this same year, the Canadian Human Rights Commission began to audit federal government departments and crown corporations to examine their employment systems, even though the civil service did not technically fall under the larger umbrella of the Employment Equity Act. More opportunities

\footnotetext{
${ }^{78}$ LAC, RG 32, Vol. 1958. File 3360-6 Vol. 7, Canadian Ethnocultural Council, "On the Sidelines of her Majesty's Service: A Survey of Employment Equity for Visible Minorities in the Federal Public Service."

79 “INTERNATIONAL U.N. visitors study Discrimination,” The Native Perspective Vol. 1 No. 8 (Aug 1976), 9.
} 
in the civil service were also opened to the target groups of Indigenous peoples, visible minorities, disabled persons, and women through a 1988 Employment Equity Exclusion Approval Order. ${ }^{80}$

Besides responding to international pressures, such changes also reflected some other important domestic initiatives. In 1983, a Royal Commission on the Equality of Employment was also established and headed by Justice Rosalie Abella. ${ }^{81}$ The commission spoke directly with Indigenous communities. It discovered that special recruitment programs designed to increase Indigenous employment in the civil service were viewed as inadequate due to the high educational requirements of programs and the limitation of how many positions would be offered to Indigenous candidates through them. ${ }^{82}$ The Commission called for a mandatory Affirmative Action Program across the civil service to combat systemic discrimination. ${ }^{83}$ Systemic discrimination became defined throughout the federal government as "the exclusion [of] designated group members - women, Indigenous peoples, persons with disabilities and visible minorities - through the application of employment policies and practices based on criteria that are not job related nor required for the safe and efficient operation of the business." 84 Furthermore, although the Commission interpreted systemic discrimination to be unintentional, it

\footnotetext{
${ }^{80}$ Many of the details in this paragraph were found in LAC, RG 32, Vol. 1949 File 1110-J1.

81 "History of Employment Equity in the Public Service and the Public Service Commission of Canada," 20; Rosalie Silberman Abella, Report of the Commission on Equality in Employment (Ottawa: Government of Canada, 1984), 2.

${ }^{82}$ Ibid., 37.

${ }^{83}$ Ibid., 193.

${ }^{84}$ LAC, RG32 Vol. 1958 File 3360-6 Part 9, "Employment Equity-General Reports, Statistics, Studies, Surveys Part $\# 9, " 1$.
} 
was nevertheless recognized as the root cause of the lack of opportunity Indigenous workers faced in government employment. ${ }^{85}$

Shortly afterward, the Public Service Commission was shocked to ascertain that only 0.3 percent, or 10 Indigenous employees, had reached the management level. ${ }^{86}$ Affirmative action meant two new mandates. First, the PSC and TBS would require better statistics to measure Indigenous employment in the civil service in comparison with the availability of Indigenous workers in the Canadian workforce. Secondly, an additional Special Recruitment Program titled the National Indigenous Development Program (NIDP) was created in 1983. The NIDP was similar to the Northern Careers Program in that it encouraged Indigenous employment in middle and senior positions. The NIDP, however, was designed for all of Canada. Incentives were provided to hiring departments by the Public Service Commission's decision to share half the cost of the salary and training of Indigenous employees hired into the civil service through these programs. ${ }^{87}$ These newfound policies recognized that few Indigenous employees were able to reach middle and senior management ranks in the civil service without specialized recruitment.

These concerns regarding workplace equity and representativeness could not be adopted without care into Canadian policy. The federal civil service already promoted the merit principle as a guiding policy for staffing to ensure that the most qualified candidates would be given employment as opposed to acquiring new hires through political favoritism. Concerns had been raised in Canada that the merit principle might not be compatible with employment targets and quotas designed to recruit and hire minority groups into the civil service over other groups in

\footnotetext{
${ }^{85}$ Ibid.

${ }^{86}$ Public Service Commission, Annual Report, 1983, Table 15, 72.

${ }^{87}$ Ibid., 18.
} 
Canada. ${ }^{88}$ Moreover, an Indian Preference Law already existed in the United States and policy makers observed how Indigenous women and men were placed into American public service positions primarily for statistical purposes and without necessarily having the qualifications to complete their jobs. ${ }^{89}$ This neither benefitted the American government nor Indigenous communities in the United States.

Canadian policy makers sought to differentiate their measure from American style quotas by changing the merit policy to include representation for Indigenous communities and other minority groups within the civil service, but not at the expense of being qualified for such work. In Canada, consequently, the emphasis began to be placed on the removal of barriers for qualified Indigenous candidates. ${ }^{90}$ The Royal Commission on Equality in Employment titled this new approach as "Employment Equity." "This removed the focus from the Indigenous candidates and placed the issue squarely on examining the civil service as an employer that could improve their employment practices and systems to create a barrier free workplace. Consequently, the Public Service Commission and the Treasury Board Secretariat defended the evolving merit policy as a long-term restructuring of the civil service into an equal opportunity employer. They would incorporate an adequate representation of minority groups into the civil service as these employees increased in number and opportunities for recruitment became equally available for candidates of all backgrounds. Targeted recruitment programs were considered a necessary temporary measure to ensure Indigenous workers were identified as

\footnotetext{
${ }^{88}$ Public Service Commission, Annual Report, 1981, 17; Public Service Commission, Annual Report, 1982, 10.

${ }^{89}$ Melissa Lazore, "Natives and the Public Service Commission," The Native Perspective, Vol. 2, No. 4 (1977): 22 23.

${ }^{90}$ Public Service Commission, Annual Report, 1982, 10.

91 "History of Employment Equity in the Public Service and the Public Service Commission of Canada," 20; Abella, Report of the Commission on Equality in Employment, 20.
} 
candidates and had access to employment positions in the civil service. ${ }^{92}$ By the 1990 s, employment equity was considered to be an essential characteristic of not only a representative civil service, but a diverse, resilient, creative and efficient civil service. The civil service was understood to grow from the collective strengths of Canadians of all backgrounds who have contributed to the running of the country. ${ }^{93}$ The representation of Indigenous employees has since greatly expanded in the Canadian civil service. In 2006, the workforce availability of Indigenous workers grew to $3 \%$ across Canada and $4.9 \%$ of all appointments throughout the civil service were from this target group. ${ }^{94}$ The merit principle, including the concept of representativeness, has become recognized internationally as a model of government policy and also one in which the Public Service Commission has been proud to help create. ${ }^{95}$

\section{Life Stories}

This thesis is centered on the life interviews of seven Indigenous civil servants who lived during these structural changes in the Canadian federal civil service. Interviewees have generously provided their experiences and memories of employment within the federal government between 1965 and 2014. The use of a living archive was a purposeful methodological decision. A more traditional approach to labour history would have examined the integration of Indigenous employees into the Canadian federal bureaucracy through archival research into fonds of the federal government. The result, however, could have been a

\footnotetext{
${ }^{92}$ LAC, RG32 Vol. 1958 File 3360-6 Part 9; "History of Employment Equity in the Public Service and the Public Service Commission of Canada," 20; Abella, 21.

${ }^{93}$ PS 2000: Reports and Summaries of the Task Forces. Ottawa, August 14, 1990.

${ }^{94}$ See Table 1 in Public Service Commission of Canada, "Appointments to the Public Service by Employment Equity Designated Group for 2012-2013 - Statistical Update," Last Modified 10 March 2014: http://www.psccfp.gc.ca/adt-vrf/stat/2012-2013/ee/index-eng.htm.

95 "History of Employment Equity in the Public Service and the Public Service Commission of Canada," 29.
} 
celebratory institutional history of the civil service as an employer dedicated to the development of programs and policies of workplace equality since the 1970s. Firstly, a careful and thoughtful institutional report on this topic has already been written. It may be found easily on the website of the Public Service Commission. ${ }^{96}$ Such a history, however, is written in the aggregate and it does not teach us very much about specific historical experiences. It also, I will argue, masks the great diversity of experience and identity that a category such as "Indigenous civil servant" simplifies and obscures. To both demonstrate this diversity and to contribute to further study, I have adopted a life story interview methodology. Indeed, as stated earlier, the primary goal of this thesis is to include the voices of Indigenous federal civil servants within the larger historical record on this subject; secondly, it has been my intention to archive oral interviews on this topic so that future researchers, Indigenous narrators, and their communities can access and benefit from these life stories in future. ${ }^{97}$

The life stories I collected sought to place the memories of work in the civil service in greater biographical and historical context. I feared that leading interviewees to only discuss their memories of work with a focus on their indigeneity might result in a thesis that precluded the inclusion of other issues that, I show later, were of equal importance to research participants such as class, gender, community, or the home. In this, I have been partly influenced by the collaborative methods of Ruth Phillips who has addressed the challenges of ethical research partnerships with Indigenous communities in a post-colonial age. According to Phillips,

\footnotetext{
${ }^{96}$ Public Service Commission of Canada, "History of Employment Equity in the Public Service Commission of Canada," Last Modified 25 October 2011: http://www.psc-cfp.gc.ca/plcy-pltq/eead-eeed/rprt/ee-psc-cfp/indexeng.htm

${ }^{97}$ The majority of life interviews from the Remembering the Civil Service project will be deposited in Archives and Research Collections (ARC), the archive of Carleton University. This will not apply to interviews with anonymous research participants which will be destroyed at the close of the study.
} 
researchers have to ensure that the goals and desires of participants are encompassed within research studies. Furthermore, collaborators must also have the ability to comment on the final product of their interview so that they do not feel misrepresented. ${ }^{98}$ Consequently, when delving into the environment of equality in the Canadian civil service, I have been very sensitive to the fact that interviewees may prefer to answer different questions and even to provide answers that seem removed from my own central research objectives. I have also been inspired in this respect by Julie Cruikshank's work on the life stories of Indigenous women's lives in the Yukon and their memories of and experiences with the Klondike Gold Rush. ${ }^{99}$

Examining the movement of Indigenous employees into the civil service based on purely aggregate data would be flawed due to the problematic nature of the statistics available. Famous heads of the civil service can be studied in available source material but the experience of regular employees in lower paid, lower echelons of the civil service can never be ascertained easily in the archive. As mentioned earlier, all Indigenous employees were largely invisible in records of the Canadian civils service until the 1980s when a consistent effort was made to procure these statistics. For example, in 1960, 123 Indigenous teachers were documented as working for the Department of Indian and Northern Affairs. ${ }^{100}$ We cannot know from these statistics, however, where these employees were recruited from geographically, nor if they included Inuit, Métis, or non-status Indigenous peoples. The purpose of these statistics was often related to the

\footnotetext{
98 These remarks were made by Professor Phillips in the context of a lecture she gave at Carleton University, Ottawa, on 12 November 2012. They were also reiterated throughout the course that I took with her during the fall term of 2012.

${ }^{99}$ Julie Cruikshank, Life Lived Like a Story: Life Stories of Three Yukon Native Elders (Lincoln: University of Nebraska Press, 1990).

100 “The Minister Reports a Review of Indians Affairs,” Indian News Vol. 4, No. 4 (Ottawa: April 1961), 6.
} 
documentation of assimilative or integrative government efforts. They do not provide a reliable statistical account of all Indigenous employees across the civil service more generally.

Furthermore, aggregate data regarding Indigenous civils servants in the post-1980s periods does not teach us much about their identities nor on-the-job experiences. My life story interviews help to remedy this. It has been possible to learn what employment in the civil service has meant to individual Indigenous employees by asking them directly. This includes learning what role work has played generally and how the civil service has been viewed specifically within the larger life of each interviewee. As shown in the following chapters, I learned from narrators that their work as civil servants mattered to their sense of self in varying degrees depending on the type of work and the environment of this work. Furthermore, Indigeneity was not necessarily associated with their economic identity as civil servants. For employees who worked with and for their communities, their work could be very closely identified with their understanding of self as a representative of their cultural community. However, other individuals placed a marked emphasis on the separation of their cultural identity and their work in the civil service.

Working with oral histories has posed its own unique challenges at the same time it has produced rewards. One such challenge includes the reality that not all, or even many, Indigenous civil servants can be interviewed within the scope of a life interview study. Researchers can never generalize from these individuals. Those who are heard are often also those who volunteered to provide their stories. I can only tell the stories shared with me. Sometimes, this has meant that I have been unable to include stories from individuals who did not agree to share their stories on the record. This thesis would have been remarkably different if all candidates had participated. Feminist oral historians Susan Armitage and Sherna Berger Gluck have argued that oral historians hear from "the survivors" in history: "They are the women who found what you 
refer to as 'coping strategies' that worked, the women whose families 'allow' them to speak, the women who are still alive." ${ }^{101}$ All of the interviewees in this study have been urban, educated Indigenous women and men who worked in white collar positions in the civil service. They have undoubtedly been a privileged group when drawn from all Indigenous workers in Canada, and thus I resist making too many generalizations from their experiences and memories of them.

Collaboration with research partners offers many rewards to the historian who incorporates the public into the writing of social histories. When people are your archive, however, the historian becomes subject to a more rigorous level of ethical obligation. Firstly, researchers who draw on the memories of members of the public have a duty to benefit those who cooperate in their research project. This includes seeing the project through to the final stages of the study, come what may. Furthermore, the researcher must make good on any offerings they have claimed the study will provide to interviewees as a result of participation in the study. In the case of this thesis, research participants can have their interviews archived should they wish and they may also obtain a copy of the final thesis. One research participant provided the story of his father to the study and has consequently requested any source materials that identify his father to be made available to him at the close of the project.

Furthermore, researchers ought to be sensitive to the shared authority of the interviewee over their own life story by ensuring that the overall meaning the interviewee attributes to his/her life has been captured in the research. Researchers can deviate from this meaning when they interpret the life story, but the interviewee's perspective can never be lost nor excluded. This is the key

${ }^{101}$ Susan Armitage and Sherna Berger Gluck, "Reflecting on Women's Oral History: An Exchange," Frontiers: A Journal of Women Studies Vol. 19 No. 3 (1998): 8. 
principle of Michael Frisch's "shared authority." ${ }^{102}$ Moreover, oral historians also commit to an even further principle of "sharing authority" within the interview process. ${ }^{103}$ More specifically, narrators are not merely a means to acquiring information about a topic but are primarily a valued resource with rights over the narration of their story during the interview - providing the stories they wish, in the narrative frame they choose.

In this thesis, sharing authority has meant that I approached stories of work in the civil service with an open mind. I had a list of possible interview questions, but these did not confine interviewees in the study. Instead, interviewees directed me through their stories to an understanding of the civil service as an employer, of the meaning of work in their life, and the role of this experience within their larger life trajectory. I did not ask interviewees to speak only to work experiences, but to share their life stories, guiding me through their work experiences as they chose to do so. I waited until the end of each life story interview to ask questions regarding race, class and gender so as not to lead narrators. They led me. Indeed, while I was inspired by some broader research questions about Indigenous civil servants, I did not start the project by searching to fill a gap in research, but by listening to my collaborators. It was through their stories that I learned what historiographical gaps might be filled. In this way, life story interviewing has taught me to be open to the idea of working together with members of the public to form an understanding of the past. Instead of writing about Aboriginal communities through the professional distance of a traditional archivist/historian, I have used my training to collaborate with Indigenous narrators, guiding them as they tapped into and knit their first-hand

\footnotetext{
${ }^{102}$ Steven High, "Sharing Authority: An Introduction," Journal of Canadian Studies Vol. 41, No. 1 (Winter 2009): 12-34; Anna Sheftel and Stacey Zembrzycki, "Introduction," Oral History Off the Record: Toward an Anthology of Practice, Edited by Anna Sheftel and Stacey Zembrzycki (New York: Palgrave MacMillan, 2013), 7.

${ }^{103}$ Anna Sheftel and Stacey Zembrzycki, "Introduction," Oral History Off the Record: Toward an Anthology of Practice, Edited by Anna Sheftel and Stacey Zembrzycki (New York: Palgrave MacMillan, 2013), 7.
} 
memories into life narratives. I then compiled these experiences into a history of the civil service that is true to their lives and experiences as middle class Indigenous women and men. Their stories could not have been told through traditional archival sources. They remedied this by gracefully becoming living archives.

When used in conjunction with other sources, life stories can provide a more textured understanding of the past. Collaborating with the community studied can also help the researcher move past their own biases to learn how people remember their own work histories and what that work means to them today. Life stories provide us with an opportunity not only to study the inclusion of marginalized communities into the wage economy, but to methodologically include subaltern groups in the process of their own histories-in-the-making.

In Chapter Two of this thesis I reveal the methodological fabric weaving together these life and work histories: the relationships built and negotiated between the collaborators and the researcher. I introduce each of the narrators in the study and provide them with an opportunity to explain for themselves why they chose to participate and what benefits they hoped to receive as a result of this cooperation. These narrators exercised agency not only in their life stories but also in their provision of these memories and experiences within the study. I consequently discuss how these interviewees set their personal boundaries and limits in the study as we negotiated the demands of participation on the interviewee and the reciprocal obligations of the researcher. The initial design and the kinks in the fabric as these goals were realized in the interview process, (most of the time), have also been outlined. Through this chapter I hope to provide a foundation for discussions of the civil service drawn from interviews by contextualizing the process in which interviews were gathered. 
Chapter Three focusses on the experiences and memories of narrators as employees of the Canadian federal civils service since the late 1960s. I specifically examine how each interviewee entered the civil service, how they negotiated their employment during their careers, and workplace opportunities, and the meaning of this work in their lives. This chapter also examines the extent to which each narrator perceives race to have affected their employment in the civil service and their identity as employees. For the most part, however, the stories of work as shared with me have been unique and grounded in individual experience. I have found that anecdotes surrounding work speak to life meaning and not just to a definition of cultural or economic background.

Chapter Four does something rare by presenting two first-person life story narratives told by the same person side by side. Oral historians are fascinated with presentations of the self. By examining the memoir and life story of Jaime Koebel as provided in 2007 in a written text and then to me orally in 2013, it has been possible to see the extent to which the presentation of self depends on the time of the telling, the form of the story, and the meaning and truths attributed to our lives. The role of work can also be examined more closely within the life of an individual. In chapter three, working lives were analyzed together to focus on the civil service as an employer of Indigenous workers. Chapter Four more clearly showcases the different forms of paid and unpaid work that fluctuate within the life of Jaime Koebel, a Métis woman, mother, community worker, and paid employee. Mary Jane Logan McCallum has similarly found that Indigenous women interviewed in her study of domestic servants likewise framed their stories of wage work alongside the themes of home, community, social assistance, and violence. ${ }^{104}$ Jaime Koebel

\footnotetext{
${ }^{104}$ Mary Jane Logan McCallum, Indigenous Women, Work, and History 1940-1980, 25.
} 
shows poignantly how work does not begin and end with paid work for the federal government, nor does this work define their identity as workers.

The Conclusion of this thesis re-examines many of the key questions that are set out in the first pages of this introduction. I will draw on the experiences and memories of all narrators represented in the thesis, as well as secondary and primary research that relates to these conclusions. Together, we will discuss the themes of identity, the regulatory culture of the civil service, and the role of race in employment for the Canadian civil service. In this way, I continue to work from the interviews outward in commentary on the civil service as a workplace. The thesis moves from a wide focus on the civil service within academic literature, to perceptions of the civil service by several employees over time, to the role of work in the civil service within an individual life. I keep with the organization of the thesis as a whole by including individual voices in the conclusion, and differentiating between these voices and my own. 


\section{Chapter Two}

\section{Ethics, Subjectivity, and Collaboration}

I learned through Dante that the idea of us 'giving voice' to the voiceless is nonsense. Dante was not voiceless, I was. I could not sing, I had no stories to tell, and I was only able to write because people like Dante gave me a voice. I returned the favor by listening and amplifying their voices...

\section{-Alessandro Portelli. ${ }^{1}$}

The majority of what I can know, what I have learned, and how I have come to document the experiences of Indigenous workers in the Canadian federal public service has been due to the methodological underpinnings I chose to employ throughout this study. This history could not have been written without the generous assistance of six individuals who shared their time, their trust, and the story of their lives with me. I am deeply in their debt. In the above passage, Alessandro Portelli captures the spirit of oral history as one of partnership and mutual purpose. Scholars owe their interviewees more than gratitude: researchers must listen with care, respect the voice of each narrator, and frame their stories as history in an ethical and scholarly manner.

This has been no small task within this study. I have been challenged to historicize work stories that address vastly different departments of government, job descriptions, periods of employment, and the degree to which interviewees have perceived equity in their different work environments. I set out with the intention of comparing workers' experiences but found myself actually learning deeply about the ethical boundaries of oral history, the role of subjectivity in research, and the construction of meaning. I began to question the role of memory and narrative

\footnotetext{
${ }^{1}$ Alessandro Portelli, "Afterword," Oral History off the Record: Toward an Ethnography of Practice. Edited by Anna Sheftel and Stacey Zembrzycki (New York: Palgrave MacMillan, 2013), 276.
} 
in oral interviews and how these factors played a large role in molding what might be learned about Indigenous experiences in the civil service. Furthermore, the act of weaving such distinct lives together as a historian presented more points of divergence than consensus; it was the process in which interviews were conducted that presented the most thrilling connections.

This chapter offers a critical reflection on how Remembering the Civil Service emerged and evolved as a research project. It considers how relationships were formed, maintained, and sometimes rejected; the methods in which "sharing authority" was negotiated with collaborators; and the path along which my own scholarship was continually rehashed with a view to finding a balance among the voices of multiple narrators and that of my own. Comparing and contrasting several oral interviews within a single chapter, and along a particular theme as I do in Chapter Three, doubtlessly involves a serious effort by the historian to craft a historical argument, blending portions of unique life narratives into a cohesive unit. My concern therefore has been that the individuality of research participants, who exercised varying degrees of agency in their respective workplaces, have not been provided equal visibility in the following chapters. I therefore allocated this chapter to unravelling the context in which several narrators participated in the study and told their stories. In this way, I hope that the discussion of the research process will allow more space for interviewees to be portrayed as research partners who each set their own level of engagement with the project.

Oral historians have become increasingly aware of the value of respectful research relationships as leading to open and rewarding interview experiences for both scholar and collaborator. The interview has now become widely accepted as "... a process in which two people work hard to understand the views and experiences of one person: the interviewee." Henry Greenspan and Sidney Bolkosky have worked with holocaust survivors seasoned in the art 
of providing interviews and giving testimonies. Through conducting focus groups, they differentiated between the two genres, finding the interview to be the result of a shared endeavour to release interviewee experiences. By contrast, they defined the testimony as a onesided dissemination of personal history. Overall, the majority of the holocaust survivors in their study preferred the richly textured result of the interview environment. ${ }^{2}$ This joint authorship has raised ethical questions in the discipline of oral history as scholars have sought to understand to what degree they as researchers shape the narrative produced in oral interviews and how best to encourage a fruitful interview exchange.

Historians have become increasingly concerned with the means by which their research relationships affect stories told within oral interviews. Although relationships with the public have involved a degree of partnership, they have not always been based upon equality. In 1990, Michael Frisch charged historians to strive for a higher level of ethics in his path breaking work A Shared Authority: Essays on the Craft and Meaning of Oral and Public History. ${ }^{3}$ Frisch argued that it has not been enough for the historian to write traditionally excluded groups into larger histories, interpreting experience from "a safe moral distance;" historians must instead listen to the message presented by collaborators and ensure all voices have been heeded in the resulting work. ${ }^{4}$ This has been an important shift in history writing because what Frisch recommended was the movement away from elitist history to a more collaborative history. Specifically, he sought to recognize the equal authority of both the narrator, holding lived

\footnotetext{
${ }^{2}$ This paragraph owes much to Henry Greenspan and Sidney Bolkosky, "When is an Interview and Interview? Notes from Listening to Holocaust Survivors." Poetics Today 27:2 (Summer 2006): 431-449.

${ }^{3}$ Michael Frisch, A Shared Authority: Essays on the Craft and Meaning of Oral and Public History (Albany, New York: State University of New York Press, 1990).

${ }^{4}$ Ibid., 59-71.
} 
experience, and the researcher, bringing training to the interpretation and analysis of stories from the past. This relationship of equality meant a consciousness of a shared authorship, otherwise known as "a shared authority."5

Since Frisch, oral historians have moved from 'a shared authority' to 'sharing authority' across the entire research process as a means to address the unequal power relationships between historian and narrator. ${ }^{6}$ This means that scholars share not only the interview room with their research partners, but also interpretive power over the final product. ${ }^{7}$ Oral historians have continued to make authorial decisions in their scholarship. At the same time they have improved their awareness of these issues so as to work toward greater overall equality, even while acknowledging that some inequality is inevitable. In this way they have enhanced the opportunity of collaborators to speak "through" them. ${ }^{8}$ The equal exchange of information and power ideally should continue well beyond the interview into the writing stage of oral research. This will hopefully create a truly fair representation of interview participants in the final report. ${ }^{9}$

\footnotetext{
${ }^{5}$ Ibid., xviii- xxiv.

${ }^{6}$ Anna Sheftel and Stacey Zembrzycki, "Introduction," Oral History Off the Record: Toward an Anthology of Practice, Edited by Anna Sheftel and Stacey Zembrzycki (New York: Palgrave MacMillan, 2013), 7.

${ }^{7}$ Steven High has recently outlined the difference between 'a shared authority' and 'sharing authority' in his article: Steven High, "Sharing Authority: An Introduction," Journal of Canadian Studies Vol. 41, No. 1 (Winter 2009): $12-$ 34; A good example of sharing authority, and the struggles in doing so, can be seen in the following articles: Stacey Zembrzycki, "Sharing Authority with Baba," The Journal of Canadian Studies Vol. 43, No. 1 (Winter 2009):219238; Katherine Borland, "That's Not What I Said: Interpretive Conflict in Oral Narrative Research,” Women's Words: The Feminist Practice of Oral History, Edited by S. B. Gluck and D. Patai (New York: Routledge, 1991): 63-75; and Lorraine Sitzia, "A Shared Authority: An Impossible Goal?" The Oral History Review Vol. 30, No. 1 (Winter-Spring 2003): 87-101.

${ }^{8}$ Portelli added emphasis to this concept of collaborators speaking through the researcher: Alessandro Portelli, "Research as an Experiment in Equality," The Death of Luigi Trastulli, and Other Stories: Form and Meaning in Oral History (Albany, New York: State University of New York Press, 1991), 56.

${ }^{9}$ Ibid., 31.
} 
I have carefully considered questions of authorial power and how best to democratize the research process in the Remembering the Civil Service Study. I chose to interview First Nation, Métis and Inuit federal civil servants broadly across government departments, levels of bureaucracy, status of employment, and geography within Canada so as to solicit a wide array of Indigenous experiences in the study and limit my own role in the selection process. I conducted local interviews in person and offered long distance telephone sessions to research partners outside the Ottawa area. Any self-identifying Indigenous person who worked for a period of time in the federal civil service could participate in the project and their experiences would be included.

I advertised the study in person at the Champlain Colloquium at Carleton University in September 2013 and also attended numerous social events through Carleton's Centre for Aboriginal Culture and Education. Furthermore, I affixed project posters in selected parts of the Carleton University campus and at the Odawa Native Friendship Centre. The Call for Participants was disseminated by the Department of History at Carleton, the Carleton Centre for Public History, the Worker's History Museum, Minwàdjimowin (the CACE newsletter), and The Graduate (the newsletter for Carleton's Faculty of Graduate and Postdoctoral Affairs). Information about the study was also circulated through social media outlets such as Facebook, Twitter and through the project website (www.rememberingthecivilservice.com). All of these recruitment initiatives occurred during the 2013-2014 academic year. Radio announcers at CKCU FM thoughtfully discussed the project with their contacts in the fall of 2013, assisting in the location of study participants for this research study. During this process, it became evident to me that the pool of interviewees would be limited due to my own language barriers. I unfortunately did not feel comfortable conducting interviews in French and regretfully had to 
decline interested francophone speakers who might have been included. In this respect, the research study reflected an English or bilingual demographic.

My chief approach to building collaborative interview relationships has been through maintaining an open dialogue regarding the purpose of the study and the process in which research would be conducted. I have been open to accommodating research participants' needs and desires over the duration of the study. Originally, interviews were designed to be one hour in length and a single session only. This meant that the work of building relationships and trust for all parties had necessarily begun prior to the narration of each life story. I provided both formal and informal opportunities for the interviewee to become familiar with the project and with myself as a researcher. This included circulating the consent form, an introductory letter explaining what the study entailed, and also a reflection sheet revealing the questions I was most interested in covering during an interview. I followed this introductory stage with a pre-interview over the phone. During this time I attempted to fully disclose the aims, goals, and expectations of the project. This oral history study was originally designed to help populate gaps in the historical record by recording the unique perspectives of current and former Indigenous staff members who have worked for the Canadian federal civil service. The secondary function of the study was to preserve the memories of Indigenous interviewees by archiving both audio interviews and written transcripts in Archives and Research Collections (ARC) at Carleton University. Many decisions were therefore made prior to collaboration with the public.

It would have been possible to have chosen alternative routes to an understanding of the civil service. This study could have provided questionnaires to participants. This would have required a smaller time commitment from interviewees and might have therefore resulted in a larger subject group for the study. I could also have chosen to complete interviews that centred 
only on the working life of each individual, specifically zoning in to the civil service through a question and answer format. Interviewees might have simply and efficiently answered a set number of preconceived questions on the day of their interview. In addition, research participants who turned away from the project due to concerns about sharing their life stories publically may have felt more comfortable with firmly outlined question parameters centering on work, and touching less on their personal lives.

I chose to pursue life stories instead. Such stories provided a great deal of context for work stories that could better situate the role of work within the life of each narrator. It might not be possible to gain this insight should I have excluded outside information regarding the narrator's life as a whole. In doing so, I learned that work was intertwined with experiences at home and in cultural communities. Life story interviewing also allowed each research partner to tell their own story in the interview room, prioritize life meaning as they perceived it, frame the importance of work in their lives in relation to other aspects of their experiences, and verify their story before it was included in the thesis. When working with a vulnerable population, I felt an additional obligation to employ the methodology of sharing authority by providing research partners transparency in understanding the aim of the study, agency in their telling of their story in the interview room, accountability in maintaining narrator emphasis within both interviews and the thesis based on these interviews, and a more careful representation of the actual importance of the role the civil service held as an employer in their lives in comparison with other aspects of their lives. Such insights would not be possible through purely quantitative interviews which do not allow for researchers to access individual voices.

The pre-interview also included discussions surrounding what the interviewee could expect from me during the process and what I hoped they would invest should they participate. I 
would guide participants through the interview, create written transcripts made from audio recordings, cooperate with participants to make these transcripts as complete and accurate as possible, and be sure that the story of each research partner would be heard in the thesis. We also discussed expectations for participation in the study. The narrator would be asked to attend a one-hour interview, share their life story, and verify the interview transcript to ensure issues of clarity would be addressed. I talked informally with interviewees before signing the consent form to ensure they fully understood the implications of their participation. Collaborators therefore had multiple opportunities prior to their interviews to ask questions, decide if they truly desired to participate and, most importantly, to discuss what they preferred to be 'on' or 'off' the record. ${ }^{10}$ Accommodating interviewee requests for anonymity or transcript alteration became the most direct instance in which interviewees controlled their level of participation in the project and the messages they would be associated with in the study. The pre-interview was a key moment in which collaborators could establish the terms of their participation.

Ideally, all research partners would participate fully in the project, making their experiences available for researcher assessment in the thesis and allowing a copy of the written transcripts to be archived at the close of the project. Interviewee safety, however, has been a primary concern of this study. Some research participants required special conditions in the project to avoid personal risk. This included both full anonymity and also minor redactions and alterations in written transcripts. Such measures have ensured that no information harmful to the interviewee would be cited in the thesis or included within interview transcripts deposited at Carleton University's Archives and Research Collections (ARC). The issue of anonymity has been problematic for researchers. According to Valerie Yow, historians are arbiters of social

\footnotetext{
${ }^{10}$ Sheftel and Zembrzycki, "Introduction."
} 
memory for future generations and have a duty to provide as full an account as possible for the historical record; at the same time, they must also protect their interviewees from any harm that might result from their contributing information to this collective memory. ${ }^{11}$ Yow has argued that it is only acceptable to delete information from the historical record when it poses certain risks to the narrator and when removal will not affect public understanding on the subject being studied. $^{12}$

In the Remembering the Civil Service study, all research participants approved the final version of their written transcripts as a firm condition for participation in the project. Yow has argued that narrators are best placed to interpret where harm may lie when interview materials have been made available to the public. Occasionally, I perceived some statements to compromise the interviewee by not being politically correct, sensitive to fellow colleagues, or because they included intimate details that would affect their reputation. Both historian and research partners therefore have to work together during the transcript review process to mitigate this potential harm. ${ }^{13}$ In this project, two individuals requested full anonymity with transcripts destroyed at the close of the study. This has resulted in a loss of some information, and a limit on the interpretation of interview material. According to Alexander Freund, this silence does not always function as passivity but can demonstrate an active choice by the research participant. Narrators have carefully decided what they will discuss with researchers and what they feel they

\footnotetext{
${ }^{11}$ Valerie Yow, "Ethics and Interpersonal Relationships in Oral History Research," The Oral History Review Vol. 22, No. 1 (Summer 1995), 51.

${ }^{12}$ Ibid., 61.

${ }^{13}$ Ibid., 60.
} 
can safely mention on the record to a public audience. ${ }^{14}$ In the transcript verification process, consequently, some changes made to the transcript, or requests to keep certain passages off the record, can demonstrate this rethinking of audience and narrative. Redactions, however, were almost without exception applied to the personal life of each interviewee and not to their experiences in the civil service. Consequently, there have been no omissions that would compromise what I believe to be the integrity of the project. There have also been advantages to transcript review. Significant additions to original interviews have been made in follow up communications. This has meant that narrator meaning has been clarified, researcher use of transcripts has been made more precise in capturing voice, and interviewees have had time to reconsider statements that may compromise their relationship with others.

One of the lessons new oral historians inevitably learn is the demanding nature of oral history on the narrators who participate. In this qualitative study, I conducted multiple telephone, email and in-person encounters with research participants. Interviewees did not only provide their stories briefly in a pre-interview, they did so fully in the official interview session. Moreover, they read through and corrected written transcripts with care (which could amount to as many as twenty-five pages). I attempted to make the study as convenient as possible by conducting sessions in person or over the telephone, at a time and location most convenient to the research participant. To minimize travel time I travelled to interviewee places of work or to public locations in close proximity to their homes.

Many potential research partners simply may not have had time to devote to this process, however. Anna Sheftel and Stacey Zembrzycki have observed that sharing authority can be a

\footnotetext{
${ }^{14}$ Alexander Freund, "Towards an Ethics of Silence? Negotiating Off-the-Record Events and Identity in Oral History," Oral History Off the Record: Toward and Ethnography of Practice, edited by Anna Sheftel and Stacey Zembrzycki (New York: Palgrave MacMillan, 2013), 232-235.
} 
demanding commitment for interviewees and that it may dissuade some from participating. ${ }^{15}$ Even within the small pool of research partners who fully completed the study, it has taken as long as three months for one narrator to attend an interview and for a second research partner to verify a completed interview transcript. Attention to time commitments went both ways, however. Some interviews were conducted over the phone and verified in the same way. Although the time of narrators was usually the most valuable commitment of narrators, at times I perceived some individuals to reject the project as a response to more deeply-rooted causes.

When researchers work with vulnerable or marginalized populations they may encounter reluctant interviewees. In her study of Bosnian war survivors, Anna Sheftel experienced difficulty in locating research partners who were willing to share their experiences on the public record. ${ }^{16}$ She contends that silence was an expression of agency for these men and women. Many of the individuals she encountered did not see the benefit of having a history recorded when that history had been a painful one. Some did not perceive how narrating their lives to an outsider could possibly be fruitful as they believed only insiders could appreciate what they had lived through. ${ }^{17}$ Sheftel concludes that these refusals to be interviewed told a story in and of themselves. Specifically, denials spoke to the perceived risk involved in scholarly research. Once given, life stories could not be retrieved; collaborators therefore sometimes avoided sharing their stories with scholars if they did not fully understand to what purpose their words

\footnotetext{
${ }^{15}$ Anna Sheftel and Stacey Zembrzycki, "Only Human: A Reflection on the Ethical and Methodological Challenges of Working with 'Difficult' Stories,” The Oral History Review Vol. 37, No. 2 (2010), 198.

${ }^{16}$ Anna Sheftel, “'I Don't Fancy History Very Much': Reflections on Interviewee Recruitment and Refusal in Bosnia-Herzegovina," Oral History off the Record: Toward and Ethnography of Practice, Edited by Anna Sheftel and Stacey Zembrzycki (New York: Palgrave MacMillan, 2013), 255-256.

${ }^{17}$ Ibid., 264.
} 
might be used. ${ }^{18}$ Bosnia-Herzegovina was a region that had known genocide; Sheftel became aware that those she spoke with considered history to have been the root of ethnic tension and distrust. Bosnians therefore categorized oral history as dangerous to social cohesion.

I encountered rejection and refusal within the Remembering the Civil Service Study as well. The most prominent instance occurred in the fall of 2013. I contacted a woman with a fairly public profile who would have certainly qualified for the project. She agreed to speak with me on the phone but was not willing to commit her story to the record. She had been terminated from her position in the Canadian federal civil service and believed this was a direct consequence of her political and social activism as an Indigenous rights advocate. She considered herself to be persecuted and was consequently wary of my background, my interest in her story, the purpose of the study, and the consequences of compliance. This was the first individual I contacted for the study. It was discomforting to find myself on hostile ground. The pre-interview quickly turned from an assessment of her eligibility for the study into a reverse interview. Nancy Janovicek has discussed this concept in her work with Indigenous populations and the back-to the-land-movement. ${ }^{19}$ She likewise encountered interview candidates who questioned her motives and the direction of her work. Like her I also noticed how collaborators have desired assurance that the history crafted from the study will not alter their life narratives. They question whether or not their stories will 'fit' within the conceptual framework employed by the

\footnotetext{
${ }^{18}$ Sheftel explains how history had been used in Bosnia-Herzegovina to solidify political rule between the 1940 s and 1990s, causing ethnic cleaning and violence. (Ibid., 256-258).

${ }^{19}$ Nancy Janovicek, “'If you'd told me you wanted to speak about the ' 60 s, I wouldn't have called you back:' Reflections on Collective Memory and the Practices of Oral History," Oral History off the Record: Toward and Ethnography of Practice, Edited by Anna Sheftel and Stacey Zembrzycki (New York: Palgrave MacMillan, 2013), 185-200.
} 
historian. ${ }^{20}$ In other words, narrators have begun to ask researchers questions regarding a shared outlook and interpretation of their story because they have concerns that their narratives may be incorporated into a narrative trajectory that may not reflect their worldview, or at least may not provide a balanced integration of researcher and narrative voice showcasing this difference of interpretation. $^{21}$

All research participants, but particularly those from a vulnerable population, have a right to know who they will be working with so that they can assess the impact of the study on their lives. This potential interview candidate certainly interviewed me quite closely: how did I come upon this topic? Did I have a relationship with any Indigenous persons? Where was I from? How did I feel about Canada's colonial past? Where did I stand on contemporary social and political debates regarding the future of Indigenous communities? Who were my parents? What did they do? What interaction with Indigenous communities did they have? In short, these questions all required a degree of introspection.

Sharing authority can be a complicated grey area as both researcher and narrator negotiate a relationship that, ideally, will lead to mutual rewards and respect. For this reluctant interviewee, explaining my background was an important caveat of gaining trust. Her needs unfortunately exceeded the scope of the study. Her narrative therefore could not be successfully included in the project without altering a study designed to be completed within only eight months. Only an ongoing, sustained, and long-term relationship would help her feel comfortable enough to participate: if I were to travel to her home community regularly, sit across from her, become a

\footnotetext{
${ }^{20}$ Ibid., 189-190.

${ }^{21}$ Katherine Borland artfully compares and contrasts the authorial interpretation of her grandmother with the scholarly interpretation of her own in Katherine Borland, "'That's Not What I said': Interpretive Conflict in Oral Narrative Research," Women's Words: The Feminist Practice of Oral History (New York: Routledge, 1991): 63-76.
} 
part of her life, and allow her the power to reciprocate my gaze and hear my story, then she could have participated and shared her own with confidence. It was regretfully not possible to accommodate a sustained, in person, out of town interview reciprocation in this way, however. If I had to identify a path regretfully not pursued throughout the project, it would certainly be the loss of a relationship with this woman. It would be fascinating at a future time to contact her again and begin a series of life interviews in the style of Julie Cruikshank. ${ }^{22}$ This would certainly provide her more of the security in sharing her narrative that she required.

Working with this research participant was still a very valuable experience; sharing my subjectivity became an essential part of outreach work with future interview partners. This was sometimes only an informal conversation, involving some of my experiences growing up in the border town of Cornwall, which straddles the nearby Mohawk community of Akwesasne. My hometown was a city steeped in stereotypes due to a high degree of smuggling occurring across the border. Although both Mohawk and non-Indigenous persons engaged and profited in this trade, the source of illegal cigarettes being at Akwesasne resulted in the informal association of criminality with the neighboring Indigenous community. Consequently, most of my initial memories involving the nearby Mohawk population involved being told never to associate with them because I could be unknowingly implicated in such traffic. This perception changed over time as I began to meet Indigenous women and men in Ottawa and learn Indigenous social history. I problematized ideas surrounding what a relationship with Indigenous community

\footnotetext{
${ }^{22}$ Cruikshank has become a renowned anthropologist, conducting life interviews over extended periods of time, allowing narrators to determine the focus of their life stories, while she builds her analysis on what can be learned from these stories after the fact. This has been a quite different approach from this research project where I aimed to interview broadly and place a special emphasis on Indigenous experiences within the Canadian federal civil service. See Julie Cruikshank, Life Lived Like a Story: Life Stories of Three Yukon Elders (Lincoln: University of Nebraska Press, 1990).
} 
members might entail in my life. I also learned about the legacy of colonization through several Canadian history classes at Carleton University and this quickly broadened my mind.

For my MA Thesis, I wanted to look not at the illegal activities perpetuated by First Nation, Métis or Inuit individuals but at the positive contributions many Indigenous peoples have made to the Canada we know today, particularly in the civil service. These are the stories I hoped to bring back to Cornwall with me. I found that tentatively sharing my true motivation and journey with others was at first very unsettling. I could not know what the response would be to this form of honest sharing and how it would impact relationships within the project. Overall, narrators appeared to be very receptive and understanding. Some were outright positive in supporting my endeavours to explore a broader Indigenous working culture in Canada. Being open with interviewees about my background became an important aspect of trust building. Reciprocal sharing engendered a more comfortable interview exchange as interviewees were no longer the only individuals revealing intimate aspects of their lives. Our interviews therefore truly became more of an 'exchange.'

Controlling individual participation in the project became a recurrent theme with interview candidates because of the real danger involved for those presently employed (job loss), those sharing life stories revealing the intimate aspects of their lives (reputation), and to those with busy schedules (time commitment). For many, the approach to sharing authority throughout the project was satisfactorily outlined in the consent form, allowing collaborators to select options that would make them feel secure in the research process. Risk was mitigated through anonymity, not attributing certain sections of our conversation to the interviewee, altering the transcript, and imposing limits on time requirements within the study. Two narrators within the study have requested full anonymity; the remainder have mixed levels of anonymity as portions 
of their story have been redacted or altered for a public audience during the transcript verification process. At some point, each interviewee made the decision that the rewards of participating in the study outweighed the inconvenience or risk of doing so.

Each narrator had particular goals and expectations in mind when they agreed to commit their story to oral history. According to Almut Leh, interview partners may have agreed to share their stories with researchers for a variety of reasons: they may have (consciously or unconsciously) desired the opportunity to secure a sympathetic listener to their life story, mull over their experiences to discern life meaning, contribute to scholarship, assist in furthering a cause that they believe in, and benefit from the social experience of interacting with another human being. ${ }^{23}$ Julie Cruikshank has also examined collaborator purpose and found the possibility of recording stories for the education of future generations has been a large motivator for her interviewees. ${ }^{24}$ Researchers must be cognizant of these incentives as they may be the key to understanding what narrators have desired to transmit to their audience.

Researchers must carefully examine the form in which stories are told and the messages emphasized by narrators to capture authorial meaning sensitively; otherwise, they risk categorizing interviewees as a means to the end of writing history. Anna Sheftel and Stacey Zembrzycki have argued that life narratives are a method by which individuals work through their memories, understand their purpose in life within their community, and rationalize how struggles and challenges have been meaningful to their identity. Life stories therefore play an

\footnotetext{
${ }^{23}$ Almut Leh, "Ethical Problems in Research Involving Contemporary Witnesses," Translated by Edith Burley, Oral History Forum d'histoire orale 29 (2009), 1-2.

${ }^{24}$ Cruikshank, Life Lived Like a Story: Life Stories of Three Yukon Elders, 340.
} 
important role in self-definition. ${ }^{25}$ It has been for this reason that misrepresenting such stories can be considered negligent and even a violation of the narrator's sense of self. ${ }^{26}$ In the interview, researchers and narrators often try to find common ground; this interest does not always continue after the interview and into the writing process, however. ${ }^{27}$ In this study, I attempted to maintain a shared voice in the interpretation too by conveying the meaning of the narrator. Henry Greenspan has commented on how such an endeavour might be made: "The more one enters into the social and cultural world of narrators rather than simply trying to extract an interview from them - the more likely it becomes that narrators' terms begin to matter. “ 28 The oral transcripts of these life stories, and the stories and memories within them, have therefore become the centre of this thesis.

A focus on interviewee message is a key priority in this study and within oral history more largely. Alessandro Portelli has outlined the strength of this field of scholarship: "The first thing that makes oral history different...is that it tells us less about events than about their meaning... Oral sources tell us not just what people did, but what they wanted to do, what they believed what they were doing, and what they now think they did. ${ }^{29}$ The oral historian consequently no longer views capturing the voice and message of research partners to be good methodological practice in collaboration, but also to be the means through which crucial insights regarding

\footnotetext{
${ }^{25}$ Sheftel and Zembrzycki, “Only Human,” 201.

${ }^{26}$ Katherine Borland, “'That's Not What I Said': Interpretive Conflict in Oral Narrative Research,” Women's Words: the Feminist Practice of Oral History, Edited by S.B. Gluck and D. Patai (New York: Routledge), 71.

${ }^{27}$ Ibid., 3 .

${ }^{28}$ Henry Greenspan, "Reflections on a Lifetime of Listening," Oral History Off the Record: Toward and Ethnography of Practice, Edited by Anna Sheftel and Stacey Zembrzycki (New York: Palgrave MacMillan, 2013), 22.

${ }^{29}$ Alessandro Portelli, "What Makes Oral History Different," The Death of Luigi Trastulli, and Other Stories: Form and Meaning in Oral History (Albany, New York: State University of New York Press, 1991), 50.
} 
intention have been gained for the historical narrative. When searching for meaning, however, researchers have to keep in mind the context in which meaning has been attributed. Human memory is subject to change over time, selectively adding and pruning memories and their meanings with continued life experience. ${ }^{30}$ Research participants consequently have made sense of their lives from the historical moment in which they have built their life stories. ${ }^{31}$ In this way, oral historians have been well placed to explore the historical past through the individuals who have lived through specific historical phenomena/events. What researchers can learn most from life stories has expanded from investigating what occurred in the past to examining the meaning of the past within individual memory.

Interview sessions were conducted over the fall of 2013 and winter of 2014. This was a particularly interesting moment to inquire into workplace equality, satisfaction, and equity as several research partners in the study have been deeply invested within their cultural communities. Interview climate at times became what can only be identified as "charged" in nature as narrative tangents occasionally burst forth, centering on the present federal government mandate in Canada and interviewee perception of current political policy in Canada. This historical moment of course has included the Idle No More movement and the continuation of the work of the Truth and Reconciliation Commission of Canada. I decided not to include political perceptions widely in the study unless directly related to their description of working in the civil service. These stories may however be accessed within written transcripts and audio records deposited at Archives and Research Collections (ARC) at Carleton University.

\footnotetext{
${ }^{30}$ Ibid., 60.

${ }^{31}$ Ibid., 61 .
} 
In this study, interviewees had complex motives for participation that could not always be linked to one impulse. Ronda Evans, for example, learned about this study through a Facebook post and appreciated the opportunity to comment on her experiences in the Aboriginal Head Start Program. She perceived the project to be "...a great way to have your say" and encouraged others to contribute to the study as well by circulating the project advertisement to former colleagues. $^{32}$

In her interview, Ronda very clearly expressed her desire to expand public awareness regarding policy and programming in the Canadian federal civil service. She explains: "maybe if somebody reads the outcome of what people had to say it might somehow make a difference to how things are done in the future. ${ }^{, 33}$ Ronda considered her narrative to be a useful contribution because she had a long career in the civil service, allowing her to comment in a balanced way upon the strengths and weaknesses of her former work environment. ${ }^{34}$ She opted to resign in 2012 when the program became increasingly centralized and less collaborative. This study was therefore one means in which Ronda might perhaps release some of the tension she bore during this period and provide a constructive critique of her former work environment. In her interview, Ronda grieved over the reduction of grassroots involvement in the shaping of federal government health and educational healing programs within Indigenous communities. ${ }^{35}$ Her interview was provided more than a year after her resignation from Health Canada and so this particular experience is prominent in the story of her working life in a similar way to how it

\footnotetext{
${ }^{32}$ Ronda Evans, Personal Communication, 31 January 2014.

${ }^{33}$ Interview with Ronda Evans, 16. (Note that page numbers refer to the final transcripts prepared and reviewed.)

${ }^{34}$ Ibid., 16.

${ }^{35}$ Ibid., 6-13.
} 
would be remembered clearly within her recent memory when stacked up against previous experiences.

Dave Monture also considered his life story to be educational for readers. He was invited to participate in the study through CKCU FM. He revealed, "I have always made it a policy where there are students...pursuing an understanding of the nature of government or decision-making in Canada...that I would cooperate as much as possible.” ${ }^{36}$ Such an endeavour can largely be seen in the same light as his personal work at the moment. In 2011, he began writing The Journals of the Pine Tree Chief, a fictional novel that has partly centred on his perceptions of the Canadian civil service. ${ }^{37}$ The main protagonist in his novel has been modelled upon that of the Pine Tree Chief, a traditional advisor to the Six Nations Confederacy Council. Dave intended this character to comment on contemporary social and political concerns for Indigenous communities in Canada, including decolonization.

Dave has employed this novel as a means to comment on his experiences within the bureaucracy of the civil service, as an outside consultant, and as an employee within nongovernment organizations. He especially emphasizes the insights he has gained from working with the federal government in various capacities and demonstrating how best one can seek to enact positive change. Dave has been very self-reflexive in the writing of his book, arguing that a novel can only be written from personal experience and knowledge. ${ }^{38}$ Consequently, he has written his book based upon personal efforts to ponder his life and work experiences. The Remembering the Civil Service Study has likely provided Dave with more opportunities to think

\footnotetext{
${ }^{36}$ Ibid., 12.

${ }^{37}$ Dave Monture, Personal Communication, 29 December 2013.

${ }^{38}$ Interview with Dave Monture, 9-10.
} 
through his memories, make connections between these experiences and his novel, and also act as a medium in which he might educate the public in how to advance advocacy efforts effectively within Canada for Indigenous communities.

John similarly participated in the study to assist the public. He has provided an uncommon perspective within the study; his experiences detail how career development and promotion were available to him as an Indigenous employee of the Canadian federal civil service. He was therefore efficiently able to navigate through the various echelons of management and executive track positions within the hierarchy of government. This led to his perception that the federal government in the 1990-2000 period was an excellent and equitable workplace for Indigenous staff members.

John has not acknowledged any benefit from participation in the study. Because he has opted to be anonymous, John has carefully selected and approved only work stories which would not compromise his identity. Nevertheless, John has been aware that his experiences provide a useful addition to academic knowledge.$^{39}$ However, this decision to cooperate as much as possible fits reasonably within his character as he has a long history of helping others. John formerly taught Indigenous students within an Ontario university for a short period of time. He generously devoted his own leisure time to both Indigenous youth and his cultural community in Ottawa since leaving the teaching profession. He retired from the federal civil service in the last few years to pursue external interests. These ambitions cannot be specified due to anonymity, but have been wholly devoted to cultural awareness within Canada. It has been necessary to protect John's anonymity so that he can continue this community building work. Nevertheless, John has

\footnotetext{
${ }^{39}$ Interview with Anonymous Civil Servant (John), 18 November 2013.
} 
provided as full an account of his work experiences within the civil service as possible so as to contribute to the historical record and to the understanding of the public.

Eric participated in the study only after repeat encouragement from his good friend, Anita Tenasco. I met Anita Tenasco at the Carleton University Champlain Colloquium in the fall of 2013 and she circulated information about the study to Eric. Initially, Eric did not agree to contribute his life story to the project. It was through encountering him personally at the opening of the new Indigenous space at Carleton University, the Ojikwanong Centre, that I was able to recruit him into the study. I explained the project in more detail and reassured him that all stories would be useful in the study. Anna Sheftel has argued that some individuals do not value their stories and so do not understand why others would solicit this information. ${ }^{40}$ This was certainly the case with Eric who perceived himself to be a regular guy and "just one of the gang" within the civil service. He was a very humble person who did not feel the need to be acknowledged or rewarded for his work: “I...don't need recognition for doing my job. I believe I do a good job and my boss says that I do a good job. That's good enough." If anything, he shrugged off acknowledgment of any efforts at work with humour, joking that "longevity awards are just a sign that you're getting older... ${ }^{41}$ His work experiences were very rewarding, however, and he experienced few obstacles or challenges throughout his career that he could not easily overcome.

Eric was reluctant at first to participate as he did not immediately comprehend how his story would be beneficial within the study. I explained to Eric that the project was actually designed to gather as wide a variety of experiences as possible. Consequently, if a portion of Indigenous employees did not identify their work experiences with their Indigeneity in any way

\footnotetext{
${ }^{40}$ Sheftel, “I Don’t Fancy History Very Much,” 264.

${ }^{41}$ Interview with Eric McGregor, 07 November 2013, 9-11.
} 
or feel their race to intersect with other aspects of their working life, I would certainly want to include this perspective within the study. In fact, it would be very remiss for me to know of such a point and not attempt to include it within the study. Eric became a very eager and helpful contributor to the study following this conversation.

CQ acknowledged that the project was of interest to him for two reasons. Firstly, he held a long career in the museums and heritage field and so greatly understood the usefulness of commemoration. He perceived the project to be an opportunity to assist in the acknowledgement of the long history of Indigenous contributions within the Canadian federal civil service. ${ }^{42}$ In this way, his participation would help uncover experiences that would contribute an original caveat to scholarship on Indigenous wage work in Canada. His interview greatly detailed the frustration caused due to limited career mobility in the 1980s and 1990s hierarchy of the museum and heritage sector of the Canadian federal civil service. Such experiences seem significant now, as they give voice to a sizeable group of workers. In Chapter One, I demonstrated the limited population of Indigenous employees who were able to reach managerial ranks of the civil service through a combination of census, Public Service Commission and Department of Aboriginal Affairs and Northern Development Canada statistics. Secondly, CQ has nearly reached retirement: "I'm closer to the end of my career than I am to the beginning of it" and the study is "just putting things in perspective." ${ }^{43}$ This activity therefore has been one way in which he has been able to recall his varied life experiences and consider their contribution to his sense of self in the present.

\footnotetext{
${ }^{42}$ Interview with Anonymous Civil Servant (CQ).15 November 2013.

${ }^{43}$ Ibid.
} 
Jaime Koebel has been an accomplished public speaker, youth educator, community worker, and memoirist. She has previously published a memoir in The Long Journey of a Forgotten People: Métis Identities and Family Histories. ${ }^{44}$ Her contribution to the project has been a supplementary medium in which she could address current social issues in Canada that affect Indigenous persons, such as homelessness, addiction, racism, physical and sexual abuse, and workplace equity. Her 2007 written memoir and her 2013 oral history interview have presented two different narrative trajectories of her life, which will be more fully discussed in Chapter Four. Portelli's claim that oral history functions as an access point for life meaning within a particular context becomes quite poignant when her two life narratives, compared side by side, demonstrate competing rationalizations of what happened within a life lived and why these events have been significant to her past and present identity.

John Moses participated in the study so as to publicize and further commemorate the work done by his father, Russell Copeland Moses, who passed away in early 2013. The actions and accomplishments of Russell have been included in Chapter Three of the study. His story has been especially useful as an access point to information regarding early Indigenous employment within the Canadian civil service as it existed in the 1960 to 1980 period. However, for the most part, it was regretfully not possible to access the voice of Russell in the study in comparison to other interviewees when first hand perceptions of the civil service, agency experienced at work, and the role of narrative and meaning were the subject of exploration.

In this chapter, my aim was to demonstrate how interviewees were not only sources of information, but research partners in the study. They made decisions as authors/narrators in the

\footnotetext{
${ }^{44}$ Jaime Koebel, "My Story: Reflections on Growing Up in Lac La Biche," in Ute Lischke and David T. McNab, eds., The Long Journey of a Forgotten People: Métis Identities and Family Histories (Waterloo: Wilfrid Laurier University Press, 2007).
} 
study. I provided interviewees an opportunity to voice why they had chosen to participate in this study and what they hoped to achieve through this cooperation. I assisted these individuals in presenting as thorough a rendition of their stories as possible when interviewed. This was followed by my efforts to preserve and foreground their voices in an oral history of Indigenous experiences of employment for the Canadian civil service. This chapter has outlined the means by which these stories were collected, interpreted, and presented. I have also revealed efforts at sharing authority as a researcher seeking to maintain an equal and ethical relationship with research partners. The methodology of sharing authority became important within the interview room as narrators assembled their own stories and situated memories of work within the context of their lives. Sharing authority was also significantly stressed in the interpretation process of the study. I allowed narrators to lead an interpretation of what working for the civil service as a racialized employee has entailed for them and the meaning of this work within each of their lives. I chose not to rely on traditional archival material and secondary literature to learn about the experience of working in the civil service. Instead, I liaised with the Indigenous civil servants who worked in this bureaucracy. Together, we collaboratively sought to understand their own experience and the impact and meaning such work held within their lives. This is the focus of the following two chapters. 


\section{Chapter Three}

\section{Experiences and Memories of Indigenous Employees in the Canadian Federal Civil Service}

At the beginning of my research for this thesis, I was concerned that questions about identity would be considered too personal by interviewees. What if they did not wish to discuss stories of racial, gendered, or class insecurity, and especially workplace discrimination, with a researcher like myself? I found that there was little need for this concern, however. Interviewees naturally shared stories of career successes, struggles, and a wide range of decisions made in their working lives. In other words, the women and men participating in the study carefully situated themselves within a specific set of class and power relations when charting their careers over time within the frame of their lives. The goal of this chapter, therefore, is to provide an opportunity for Indigenous civil servants to speak about their perceived roles as workers in the Canadian federal public service - detailing their career experiences and the personal meaning this work has held for them as individuals. In doing so, we gain important insight into the class formation of these people as workers.

When using the term class, this thesis has drawn inspiration from E.P. Thompson's description of class as not a structure but a set of relationships between individuals in society that involve identity, shared experiences, power, and authority. ${ }^{1}$ Thompson's pioneering social histories of class have been foundational for scholars even as they have refined and critiqued his work. Gregory S. Kealey has argued that class must be understood in two senses: "class involves the relationship of exploitation that exists between capitalist and wage labourer" and also "concerns the beliefs, values, ideas and traditions that people carry with them in their lives and

\footnotetext{
${ }^{1}$ E. P. Thompson, The Making of the English Working Class (Harmondsworth: Penguin, 1980), 9-11.
} 
work." ${ }^{2}$ Sociologist John R. Hall has weighed in on this discussion by constructing a neo-

Weberian framework of class focusing on the agency of the individual and their actions within the economy. He explains how the ability to perform certain actions in the economy has been determined by the property, work position or education of each individual. State regulation has also affected economic markets. This does not mean that individuals have no agency within the economy, but some factors outside of their control, like government regulation or family property have possibly affected their economic prospects. The more control individuals have over the means of production the less likely they will be to feel exploited in the economy. The opposite has unfortunately also been a truism in capitalistic societies like Canada. ${ }^{3}$

Feminist scholarship has built on (and sometimes away from) this traditional understanding of workers by highlighting how the experience of workers must also be understood through the intersection of gender, age, and race. ${ }^{4}$ In this way, historians like E. P. Thompson, Herbert Gutman, David Montgomery and even later historians such as Bryan D. Palmer and Gregory Kealey, have been considered to over-emphasize the role of the state in labour history and simultaneously overlook the force of gendered class relations within working lives. ${ }^{5}$ This can partly be seen through historical categories relegating women to the private

\footnotetext{
${ }^{2}$ Gregory S. Kealey, Essays in Working Class History. Edited by Gregory S. Kealey and Peter Warrian (Toronto: McClelland and Stewart, 1976), 8.

${ }^{3}$ John R. Hall, “The Reworking of Class Analysis," Reworking Class, Edited by John R. Hall (Ithaca and London: Cornell University Press, 1997), 17-30.

${ }^{4}$ Joan Sangster, "Feminism and the Making of Canadian Working-Class History: Exploring the Past, Present, and Future," Labour/Le Travail Vol. 46, Special Millennium Issue (Fall 2000): 129. Sangster's essay is a useful guide through a vast and vibrant scholarly literature.

${ }^{5}$ Ibid., 130-133; Bryan D. Palmer, Working Class Experience: Rethinking the History of Canadian Labour, $1800-$ 1991 (Toronto: McClelland and Stewart Inc., 1992): 11-33; Bryan D. Palmer, David Frank, Todd McCallum and Jacques Rouillard, "Working-Class History," Historica Canada, Last Modified 16 December 2013, http://www.thecanadianencyclopedia.ca/en/article/working-class-history/.
} 
sphere of domestic and unpaid work, while men have long been considered to work for wages. ${ }^{6}$ Examining cultural and social history since the 1980s has assisted historians in better accessing the experiences of women- including the importance of family economic strategies and the gendering of feminine and masculine occupations. ${ }^{7}$ Joan Scott has also contributed to a historical understanding of women through her deconstruction of gender categories. In her path breaking essay, Scott revealed gender classifications to be imposed definitions of meaning that governed women and men, maintaining mainstream Western values in North America through the gendered discourse of politics and power. ${ }^{8}$ In this way, feminist scholars were first to question traditional methods of writing labour and working-class histories, and in doing so, opened up competing narratives that provided a richer understanding of the past and the role of gender in circumscribing the lives of working women and men.

For marginalized populations, race has been a significant factor contributing to class positioning in Canada. Bryan D. Palmer and Joan Sangster have argued that race became an important social category of analysis for labour historians in the $1990 \mathrm{~s}^{9}{ }^{9}$ In the introduction to this thesis, I demonstrated how a heightened awareness of race existed in the Canadian federal civil service in the twentieth century; this is apparent through the dedication to research, policy, planning, and collaboration with Indigenous communities that occurred as the federal government completed a thorough internal review of the multiple ways in which race has

\footnotetext{
${ }^{6}$ Ibid., 133-134; Sonya Rose, "Gender and Labour History: The Nineteenth-Century Legacy," International Review of Social History Supplement Vol 38 Issue 2 (1993): 145-62.

${ }^{7}$ Sangster, "Feminism and the Making of Canadian Working-Class History," 136-151. Critical to this latter point was Joan W. Scott, "Gender: A Useful Category of Historical Analysis," The American Historical Review Vol. 91, No. 5 (Dec. 1986), 1053-1075.

${ }^{8}$ Joan W. Scott, 1053-1075.

${ }^{9}$ Labouring Canada: Class, Gender, and Race in Canadian Working-Class History. Edited by Bryan D. Palmer and Joan Sangster (Don Mills, Ontario: Oxford University Press, 2008).
} 
affected the recruitment of Indigenous employees. Consequently, academic researchers and departments of the civil service have undergone a parallel shift in recognizing the role of race in the economy. Consistently in my research, including the interviews, I found that Indigenous workers in the Canadian federal civil service experienced race and class through the structures circumscribing them - be they educational opportunities, race-specific hiring programs, and/or positions designed specifically for Indigenous workers in the Canadian federal public service. However, these same interviewees also fashioned their work stories around agency in the workplace as well as decision-making within their larger careers. In this way, their class consciousness involved an awareness of both the structures governing their lives and their own ability to act within, negotiate with, and resist.

This chapter braids together the work stories of John, Eric, Dave, CQ, Ronda and the late Russell Copeland Moses to provide a medium for Indigenous workers to comment and sometimes critique the bureaucracy of the Canadian federal civil service where they have been employed. The experiences of federal civil servants in the study have been highly variable, but certain themes can be traced: educational preparation for the workforce; the hiring opportunities or lack thereof; the degree of career development and mobility; and situations of workplace conflict, negotiation, and resistance. I argue that race consistently affected (and affects) Indigenous employees in the Canadian federal civil service, regardless of how much or how little interviewees associate their own racialized identities with their work. Even interviewees who were reluctant to view race as a defining element of their careers, acknowledged their fellow staff members viewed them through a racialized lens at various points throughout their working lives. As the evidence will show, race has therefore been a factor in managerial hiring decisions, 
work assignments provided to interviewees, promotional opportunities, and even overt racial discrimination in the workplace.

\section{Preparation and Entry into the Canadian Federal Civil Service}

Russell Moses was born in 1932 within the Six Nations of the Grand River Community outside of Brantford, Ontario. He attended the Mohawk Institute Indian Residential School from 1942 to $1947 .{ }^{10}$ Russell enlisted in the Royal Canadian Navy when he reached the age of majority. He served in the navy for five years (1950-1955). Trained as a Torpedo and AntiSubmarine (TAS) rating, Russell served on the HMCS Iroquois during the Korean War. From 1955-1965, he then served in the Royal Canadian Air Force as a Safety Systems Technician responsible for the maintenance of ejection seats and parachutes on Canadian planes. ${ }^{11}$ It was in 1965 that Russell moved to Ottawa with his family. Through word of mouth he learned that the Canadian Broadcasting Corporation was searching for a radio broadcaster for their northern program - Indian Magazine. ${ }^{12}$ This was a part-time position as a radio show host in CBC's Montreal studio. The program was then directed toward northern Indigenous communities. Officials at the Indian Affairs Branch of the Department of Citizenship and Immigration who listened to this radio program offered Russell employment. Consequently, in 1965, Russell retired from military service and became a civil servant within the federal branch of Indian Affairs. ${ }^{13}$ It is worth noting that in the mid-1960s, post-secondary education was not necessarily

\footnotetext{
${ }^{10}$ Information regarding the life of Russell Copeland Moses has been provided by his son John Moses: Interview with John Moses regarding his late father, Russell Copeland Moses, Personal Communication, 06 December 2013.

${ }^{11}$ John Moses, “Life Story: Russell Copeland Moses, 1932-2013,” Ottawa Citizen, June 14, 2013.

12 This circular was rebranded Our Native Land in 1970. See the CBC digital archives at http://www.cbc.ca/archives/discover/programs/o/our-native-land-1/indian-magazi.

${ }^{13}$ This information was provided by John Moses: Interview with John Moses regarding his late father, Russell Copeland Moses, Personal Communication, 06 December 2013.
} 
a strict requirement for entry into the civil service in all cases - networking, individual ability, and racial background were large factors in the employment of Russell Moses.

Russell was asked to provide a residential school testimony to his employer when he first began working at the Branch of Indian and Northern Affairs in 1965. He recalled his school memories at Mohawk Institute in Brantford, Ontario in a vivid narrative that not only described the various physical and environmental sufferings of Indigenous students but also instructed the federal government on how they might make restitution for what had occurred. His stronglyworded document was given to officials at the Department of Indian Affairs in the earliest period of his government employ. ${ }^{14}$ Attending a residential school in Canada became an important preparation for Russell Moses as a public servant due to the impact this experience had on the direction of his work in government.

Russell consistently filled positions where his Indigeneity added valuably to his work qualifications as a civil servant. In 1966, Russell became the Assistant Deputy Commissioner of the Indians of Canada Pavilion at Expo 67 where a large outdoor exhibition illustrated both the history of Indigenous peoples in Canada and the more recent social and economic conditions of Indigenous communities. ${ }^{15}$ Russell next became an advocate for Indigenous communities in government when serving as Special Assistant to Jean Chrétien, Minister of Indian Affairs and Northern Development Canada from 1968 to $1974 .{ }^{16}$ During the Alberta school boycott of 1969 ,

\footnotetext{
${ }^{14}$ Russell Moses, "Mohawk Institute - 1942-47,” 28 December 1965. This residential school memoir was provided by John Moses.

${ }^{15}$ Library and Archives Canada "Expo 67 Man and His World," Date Accessed 01 June 2014: https://www.collectionscanada.gc.ca/expo/0533020206 e.html.

${ }^{16}$ Russell Moses had a long career within the civils service, which included working during the White Paper Policy Proposal in 1969; Interview with John Moses regarding his late father, Russell Copeland Moses, Personal Communication, 06 December 2013.
} 
for example, Russell was sent to tour reserve communities to investigate their grievances. Protesters at this time boycotted schools in Alberta to draw attention to the condition of Northeastern Albertan infrastructure and living conditions. ${ }^{17}$ Finding the situation to be dire, Russell informed the press that he would be speaking for Indigenous communities when meeting with Minister Chrétien. ${ }^{18}$ Russell Copeland Moses was consequently labelled the "Indian mouthpiece in Ottawa" in media and also the "red Uncle Tom.." ${ }^{19}$ Russell was also present during the White Paper Policy Proposal as a member of Jean Chrétien's staff. In fact, Russell was on his implementation team. During the interview, John Moses reminded me that the policies his father (and fellow civil servants) had to implement in 1969 were set prior to the legal duty to consult. ${ }^{20}$ Consequently, the power to legislate policies was centralized; staff members on the implementation team were largely responsible only for execution of these orders. Specifically, Russell travelled the country to announce the White Paper Policy at town halls, press conferences and to receive feedback from the public. ${ }^{21}$

Although Minister Chrétien did attend a series of consultation meets between 1968 and 1969 in order to involve Indigenous communities in new departmental legislation, their pleas for equality, recognition of Indigenous identity, and desire for more efficient land claim and treaty

17 "Tour Cut Short," The Albertan, 02 October 1971.

${ }^{18}$ See Rossi Cameron, “Government Misinformed, Ottawa Official Charges: Indian Plight Deplored," Edmonton Journal, 1 October 1971.

${ }^{19}$ See "Indian Power Upsurge Jolts Canada's Calm," Chicago Tribune, 15 June 1969; Uncle Tom is a famous character from Harriet Beecher Stowe's celebratory 1852 novel Uncle Tom's Cabin. This book has commonly been considered a pillar of the anti-slavery movement in the United States. As Russell Copeland Moses appealed in 1969 to equality and fairness for Indigenous peoples in Canada, the term red Uncle Tom becomes quite poignant and meaningful.

${ }^{20}$ The Legal Duty to consult is a caveat of the 1982 Constitution of Canada. It directly charges the Government of Canada to consult Indigenous communities in Canada when Indigenous and Treaty Rights might be affected. See Indigenous and Northern Development Canada, "Indigenous Consultation and Accommodation - Updated Guidelines for Federal Officials to Fulfill the Duty to Consult - March 2011," 15 September 2010.

${ }^{21}$ Ibid., 5-6. 
negotiations were ignored in the resulting White Paper Policy. ${ }^{22}$ Essentially, the new legislation argued that the social problems experienced by Indigenous populations in Canada were due to their separate status as a unique people in Canada. Consequently, their interests would best be served through full integration into the larger Canadian public and the dissolution of all elements of their relationship with the Government of Canada that contributed to their isolation as a people. ${ }^{23}$ Historian J. R. Miller has contended that what is now known as the infamous White Paper Policy Proposal arose as a method in which the federal government could address the rising population of Indigenous peoples during the twentieth century, the increased cost of residential schooling, and the demand for land during the Canadian resource boom. ${ }^{24}$ This policy was very unpopular with Indigenous communities in Canada, however, and the response was profound and lasting. ${ }^{25}$ Russell's presence in the civil service would certainly have been valuable for Chrétien's consultation purposes; however, the position of Special Assistant to the Minister of Indian Affairs did not necessarily give him the power to influence change unless specifically dictated to do so from above.

Dave Monture was hired into the federal government in the 1960s and networking played a large role in his entry into the civil service. Dave was born in 1949 within the Six Nations of the Grand River Community outside of Brantford, Ontario. Dave was employed in shift work at the

\footnotetext{
22 J. R. Miller, Skyscrapers Hide the Heavens: A History of Indian-White Relations in Canada (Toronto: University of Toronto Press, 1989), 225.

${ }^{23}$ J. R. Miller, 226-227; "New Policy for Indians,” The Indian News, Special Issue (June 25, 1969) 1-3.

${ }^{24}$ J. R. Miller, Skyscrapers Hide the Heavens: A History of Indian-White Relations in Canada (Toronto: University of Toronto Press, 1990), 211-229.

${ }^{25}$ According to J. R. Miller, the White Paper Policy proposal was deeply objected to across Canada. George Manuel of the Indian Association of Alberta spurned assimilation and encouraged Indigenous peoples in Canada to take control of their futures. Manitoban Indigenous communities penned a 'brown paper' in response to the legislation and Albertan Chiefs delivered a 'red paper' to Minister Chrétien in 1970. The National Indian Brotherhood, formed in 1968, coordinates these efforts politically. See J. R. Miller, Skyscrapers Hide the Heavens, 230-233.
} 
Canadian Gypsum Company after completing high school. His uncle Russell Copeland Moses, then Special Assistant to Jean Chrétien at the Department of Indian and Northern Affairs, notified Dave in 1969 that entry level positions were available in the department if his nephew wished to apply. ${ }^{26}$ Dave described his impression of the department in his interview: "In those days, there might have been all of 12 or 14 people in the whole Department of Indian Affairs headquarters in Ottawa. So I suspect there was some effort being made to recruit."27 Consequently, at only nineteen years of age Dave left Six Nations Reserve to become a Clerk in the Records, Research and Clippings Section of Indian Affairs. This was a short-lived work assignment, however, as Dave was promoted to Editorial Assistant of The Indian News in October $1969 .{ }^{28}$ Like Russell, Dave was hired into the civil service in the 1960 s and postsecondary education was not required for his employment.

In his interview, Dave Monture explained the benefits he received as a federal employee, the chief of which he viewed to be the opportunity to have pursued post-secondary education during the course of his civil service career. From 1972-1974, Dave was provided with a paid education leave on behalf of the federal government. He attended the University of Western Ontario where he studied social sciences intensively, completing fourteen credits in only two years. He would eventually like to complete his last credit and receive his Bachelor Degree. ${ }^{29}$ Thus far, Dave has

\footnotetext{
${ }^{26}$ Interview with Dave Monture, 29 December 2013.

${ }^{27}$ Ibid., 3; By 1969 there were efforts to recruit Indigenous employees into the Department of Indian Affairs and Northern Development Canada. As part of the 1968 Indian and Eskimo Recruitment and Development Program at INAC, 120 First Nation and Inuit university students were invited to apply to the department. By 1969, INAC counted 59 employees at the Ottawa headquarters and 692 staff in the field to be of First Nation or Inuit descent. See Department of Indian Affairs and Northern Development, Annual Report Fiscal Year 1968-1969, Item 36072, 153.

28 “Indian News Appointment,” The Indian News, Vol. 12, No. 7 (October 1969), 1.

${ }^{29}$ Dave Monture is currently one credit short of receiving a Bachelor of Arts from the University of Western Ontario. See Interview with Dave Monture, 1-2.
} 
received a Certificate in Management from the Banff School of Advanced Management in 2002;

Dave was Cabinet Secretary of the Government of Yukon at this time and so this educational opportunity was also completed as a government employee. ${ }^{30}$ He now recalls these experiences gratefully. In his interview he claimed that it would have been highly difficult to attend university as a newly married young man with only the social assistance offered to Indigenous communities on behalf of the federal government. Having a paid education leave therefore was crucial to his opportunity to take classes at the University of Western Ontario. Post-secondary education consequently functioned as one of the most positive attractions and retention mechanisms drawing Dave to work for the Canadian federal civil service.

For some interviewees, educational opportunities were not only required for entry into the civil service but facilitated this access through various internships and work placements. This was certainly the case for John, an Odawa interview participant born in Sudbury in 1958. He received his Bachelor of Political Science from Laurentian University in the late 1980s and his Master of Arts in Canadian Studies from Carleton University in the early 1990s ${ }^{31}$ It was through his MA program at Carleton that John completed his first placement for the federal government. At the Department of Indian and Northern Affairs, John curated a small art exhibition from the department's fine art collection. His linguistic understanding was important to this position and John won the Deputy Minister's Outstanding Achievement Award for his work. It was through his MA placement at the Department of Indian and Northern Affairs Canada that John decided to continue working in the Canadian federal civil service. He pursued a career in the civil, working

\footnotetext{
${ }^{30}$ Dave received a BSAM Certificate in Advanced Management in 2002. Dave Monture, Telephone Communication, 05 June 2014.

${ }^{31}$ Interview with Anonymous Civil Servant (John), Personal Communication, 18 November 2013.
} 
at the Department of Indian and Northern Affairs for the next six years, filling a post in management during his final year of civil service employment. ${ }^{32}$

John has been unique in the study as an individual who has navigated multiple managerial positions as a public servant. In 2000, John was screened into the Career Assignment Program (CAP) of the federal government. ${ }^{33}$ He had applied for and was recruited into CAP as part of a special call for Indigenous candidates. John was one of the top three candidates accepted into the program. As a result, he held two executive level placements, the first in the Treasury Board Secretariat, which became his home department, and a short second placement within the Department of National Defence (both occurring in the early millennium period). ${ }^{34}$ As part of their training, CAP employees were also paired with role models holding high level executive positions in the civil service. John was mentored by the head of the Public Service Commission. He also underwent French language training as a requirement of the Career Assignment Program, and took advantage of training available to CAP employees through the Canadian Centre for Management Development (offered by Queen's University in an Ottawa satellite office). The majority of his instruction, however, came in the form of direct workplace experience. Junior Policy Analysts in the Treasury Board of Canada Secretariat worked side by side with Senior Policy Analysts on tasks and assignments. Junior Analysts were given increased responsibility over time. ${ }^{35} \mathrm{John}$ withdrew from the executive stream after four years within the

\footnotetext{
${ }^{32}$ The details of John's work and the title of his various positions at the Department of Indian Affairs and Northern Development Canada are not included in this thesis due to concerns about his anonymity.

${ }^{33}$ This initiative was launched by the Treasury Board of Canada Secretariat (TBS) and the Public Service Commission (PSC) in 1968 as a mechanism to recruit and groom qualified candidates for executive management level positions throughout the federal civil service. See Public Service Commission of Canada, Annual Report, 1968, 8.

${ }^{34}$ Some details have been removed due to anonymity.

${ }^{35}$ Interview with Anonymous Civil Servant (John).
} 
program. He opted to remain in a permanent unionized position as a Policy Analyst in the Treasury Board Secretariat until the early 2010s when he retired. ${ }^{36}$ John has a statistically unique perspective to offer in the study as an Indigenous employee recruited into executive level positions in the Career Assignment Program.

Eric McGregor came to Ottawa for the educational and professional opportunities available in the capital city. He was born in 1964 in the Algonquin community of Kitigan Zibi, Québec. An aspiring statistician, he received a Bachelor of Mathematics from Carleton University in $1986 .{ }^{37}$ His first position in the federal civil service was a summer student job in the mailroom of Employment and Immigration. ${ }^{38}$ Eric was recruited into this summer work assignment through the Career Oriented Summer Employment Program (COSEP) of the federal government. ${ }^{39}$ Employment and Immigration was a casual and enjoyable place to work, although temporary. Eric chose to pursue a career within the federal government because he felt that it was really the best economic option for someone with a statistics background. Eric stated: "even back then I remember I wanted to be working in the government. I wanted to work in Statistics Canada... I had already decided that... [but it] wasn't easy to get in." ${ }^{40}$ It took the better part of two years for Eric to realize his ambition of working permanently for the federal government.

In his interview, Eric revealed that as a young graduate he hoped his minority status as an Indigenous person would assist him with his entry into the civil service. With frankness, Eric

\footnotetext{
${ }^{36}$ Anonymous Participant (John), Email Communication, 04 January 2014.

${ }^{37}$ Interview with Eric McGregor, 07 November 2013, 1.

${ }^{38}$ Interview with Eric McGregor, 1-2; this department is now known as the Department of Employment and Social Development Canada.

${ }^{39}$ Eric McGregor, Email Communication, 17 June 2014.

${ }^{40}$ Interview with Eric McGregor, 2.
} 
explained: "I was under the [impression] that - here I am a Native kid with a math degree - ...it was going to be easy to find a job."41 Eric visited with two Indigenous Placement Officers from the Public Service Commission on a monthly basis after his graduation in 1986. Merv Sarazin from Golden Lake (now Pikwakanagan) and Larry Whiteduck from Kitigan Zibi were Indigenous Placement Officers who recruited Indigenous workers through an initiative known as the National Indigenous Development Program (NIDP). ${ }^{42}$ It was only on 25 January 1988 that Eric was successfully hired through the NIDP program and placed in the Office of the Superintendent of Financial Institutions (OSFI). He first worked as an Actuarial Assistant at OSFI but shortly afterward was transferred into the post of Pension Analyst in their Program Management section. ${ }^{43}$ Eric's experience applying for the federal public service demonstrates that in the late 1980s it was not automatic for applicants within designated minority groups to successfully access targeted recruitment programs and begin working permanently in the federal civil service; candidates also needed to be qualified for the job descriptions they would fill within government and bide their time until appropriate permanent positions became available.

For some individuals in the study, career advancement proved to be very important in their workplace satisfaction, long after being recruited into the federal public service or Canadian crown corporations. CQ displayed this very forcefully in his interview. He was born in 1962 in Quebec and self-identifies with the Six Nations of the Grand River community outside Brantford, Ontario. He has exercised his rights as a civil servant to apply for promotional

\footnotetext{
${ }^{41}$ Ibid., 2.

42 As discussed in Chapter One, the National Indigenous Development Program was instituted in 1983 to increase the representation of Indigenous employees in the Canadian federal civil service. See Public Service Commission of Canada, Annual Report, 1983, 18.

${ }^{43}$ Eric McGregor, Email Communication, 17 June 2014, 3-4.
} 
opportunities, participated in the PSAC union strike of 2009, resigned from departments where he was unhappy, and accepted new positions that were more satisfying. CQ was hired by the federal civil service in the 1980s and continues to be employed today. He moved to Ottawa with his family in the 1960s when his parents sought out new professional opportunities. He received a post-secondary Diploma in Applied Arts in Museum Technology at Algonquin College, and subsequently a Bachelor of Interdisciplinary Studies and a Master's in Canadian Studies from Carleton University. ${ }^{44}$ In his interview, CQ revealed that the impetus for completing his diploma at Algonquin college was to enter the "museum and heritage workforce as quickly as possible." 45 While applying for management positions at the Canadian Museum of Civilization, CQ completed his MA degree - a move which did not improve his vertical advancement at CMC but did assist him in acquiring his permanent position at the Department of Canadian Heritage. In the future, he aspires to complete a further doctoral degree in Cultural Mediations. He hopes this credential will enhance his post-retirement ambitions to become an independent Indigenous consultant.

The search for permanent unionized work in the Canadian museum and heritage industry was lengthy for CQ, lasting a decade before he succeeded in securing permanent employment. In his interview, CQ depicted his work experience as a "checkerboard pattern of museum work and contract work" where he "wasn't considered to be accumulating seniority." ${ }^{46} \mathrm{He}$ competed for multiple positions between graduating from Algonquin College and accessing his first permanent placement in the civil service in the late 1990s. Although job security was elusive, CQ was

\footnotetext{
${ }^{44}$ The dates of CQ's convocations from Carleton University have not been included in this thesis due to anonymity.

${ }^{45}$ Interview with Anonymous Civil Servant (CQ).

${ }^{46}$ Interview with Anonymous Civil Servant (CQ).
} 
continually employed through various civil service related contracts. CQ completed two summer internships within the federal government while studying Applied Arts in Museum Technology at Algonquin College. These placements were assigned through a federal summer student hiring program known as the Career Oriented Summer Employment Program (COSEP). CQ worked as a COSEP intern at the Canadian Conservation Institute and at the National Gallery of Canada as a summer student in the mid to late 1980s ${ }^{47}$ Upon graduating from Algonquin he began work at the Canadian Museum of Civilization through a contract under the National Indigenous Development Program (NIDP). CQ recalled how CMC may have wanted to employ Indigenous persons in the late 1980s because of the program: "[e]ssentially the NIDP program of the Public Service Commission covered half my salary while the Museum of Civilization covered the remaining half of the salary." ${ }^{48}$ When the two year placement in the NIDP program came to an end, CQ was continually offered new contracts at CMC. Unfortunately, these contracts were short-term and did not materialize into a secure position with seniority in government. Consequently, as an indigenous person, applying for a permanent posting within the civil service was challenging for CQ despite his use of targeted hiring programs to enter the civil service. ${ }^{49}$

Ronda Evans began working in the private sector before she attempted to apply for a position within the civil service. Ronda was born in 1958 in Ville Marie, Québec; she identifies with the North Temiskaming First Nation. ${ }^{50}$ Her family moved off the North Temiskaming Reserve to the city of Collingwood when Ronda was four years old. She attended St. Mary's Catholic School in

\footnotetext{
${ }^{47}$ Interview with Anonymous Civil Servant (CQ); Anonymous Civil Servant (CQ), Email Correspondence, 20 March 2014.

${ }^{48}$ Interview with Anonymous Civil Servant (CQ).

${ }^{49}$ Dates regarding CQ's employment with the civil service have been made vague due to anonymity.

${ }^{50}$ Interview with Ronda Evans, 31 January 2014, 10. The biographical details that follow come from pages 1-5 on the interview transcript.
} 
Collingwood as well as Collingwood Collegiate Institute, where she recalls being an honour roll student until grade ten. Due to various personal struggles, Ronda's education was not completed on a continual basis. Ronda was barred from her own home as a pregnant young woman at fifteen years of age. During this period, Ronda lived without the support she hoped for and made the difficult decision to give her son up for adoption. She then moved to Barrie, Ontario. Ronda was able to support herself through working a series of retail and factory jobs; she also completed high school on a part-time basis.

Ronda then began pursuing further education to enter the field of finance. She completed a tax preparation course in Barrie in 1978, after which, she subsequently moved to Toronto to work as a Tax Preparer at H \& R Block. This was seasonal employment, however. Consequently, she began working as a Clerk for an organization called the Crown Trust Company shortly afterward. Ronda transferred stocks and bonds in this position. She also studied part time in the evenings during this period to gain a Business Administration Diploma from Ryerson Polytechnical Institute in 1981. While still studying part-time, she discovered a Revenue Canada hiring campaign in a Toronto newspaper. This advertisement concerned an open competition within the federal government. In 1979, Ronda was hired through a short term contract at Revenue Canada as their CPP/UI Deficiency Clerk. This was an administrative position. In this way, Ronda was not recruited into the federal civil service through any particular Indigenous targeted hiring program, although her racial background became important during a later part of her government career. Ronda held various administrative positions until 1981. At this time, she left the civil service and enrolled as a full time student at the University of Toronto. She graduated with a Bachelor of Arts in Economics in 1985. Ronda, however, continued to hold 
summer student positions in the civil service at Canada Manpower and Immigration while studying.

Ronda returned to the federal government as a Program Officer at Canada Employment and Immigration Commission (CEIC) in 1985. In this post she worked with the public, assisting nonprofit funding recipients with the financial operations and reporting requirements expected by the department. Here she learned extensively about the relationship between the federal government and Indigenous communities in Canada and helped ensure that community programs under her portfolio ran smoothly. Ronda enjoyed this work assignment because she "... wanted to work directly with the Aboriginal community." was so glad that I got my education because it opened that door for me." ${ }^{.52}$ Post-secondary education therefore not only provided Ronda with gainful employment, but also helped her to move from administrative entry level positions in the federal government to community programming.

Although the framing of each life story differed drastically, interviewees without exception described their educational background in the early portion of their narratives. Indeed, half of the participants in this study acknowledged that their education had been either ongoing or that they would like to return to school to complete degrees left unfinished due to professional and/or personal obligations. Educational training serves as an important corollary when framing work and life stories because it functions as a chief structural factor affecting the interviewee's "relationship to the means of production and one's ability to decide the pace, nature and products

\footnotetext{
${ }^{51}$ Ibid., 5 .

${ }^{52}$ Ibid., 4-5.
} 
of their work." ${ }^{, 53}$ With the exception of Russell Moses (who worked in the 1960s through the 1980s in the civil service), all other interviewees in my research pursued some form of postsecondary education prior to entering the civil service or as career development during their working lives. For those like Russell who had little choice in their educational formation, their educational background in residential schools could nevertheless be a guiding force in their careers; Russell carried his experiences as a residential school survivor with him into the civil service where he became a known advocate for Indigenous communities in Canada. Although there were many economic factors that determined an individual's class position in the Canadian economy, it became possible for most interviewees in the study to control their socio-economic class position to some extent through pursuing an education.

\section{Navigating the Civil Service}

More often than not, research participants worked within the existing structures of the civil service to improve their personal situation rather than challenge the bureaucracy as a whole. This shared experience resonates well with scholarly literature on subaltern workers. Eric Hobsbawm has examined the methods in which marginalized workers have preferred “...working the system' to its advantage- or rather to its minimum disadvantage, [and] also of resisting and where appropriate, of counterattack."54 James C. Scott clarifies methods of 'working the system' to include "the ordinary weapons of relatively powerless groups: foot dragging, dissimulation, desertion, false compliance...feigned ignorance, [and] slander." ${ }^{55}$

\footnotetext{
${ }^{53}$ Bryan B. Palmer and Joan Sangster, "Introduction" in Labouring Canada: Class, Gender and Race in Canadian Working Class History. Edited by Bryan B. Palmer and Joan Sangster (Don Mills, Ontario: Oxford University Press, 2008.

${ }^{54}$ Eric Hobsbawm, “Peasants and Politics,” Journal of Peasant Studies 1, No. 1 (1973): 3-22.

${ }^{55}$ James C. Scott, Weapons of the Weak: Everyday Forms of Peasant Resistance (New Haven and London: Yale University Press, 1985), xvi.
} 
Cathleen D. Cahill has expanded upon these general strategies of labour resistance and negotiation by investigating the techniques of Indigenous teachers in the employ of the American federal government in the early twentieth century. Cahill argues that these Indigenous teachers mediated their workplace using professional skills gained as white collar workers - such as written communication via letter writing and verbal communication through meeting with those in positions of authority. ${ }^{56}$ In this way, marginalized groups, including North American Indigenous civil servants, have been noted for their ability to negotiate their positions at work as opposed to taking more extreme measures intended to restructure or even dismantle the overall bureaucracy. Through interviewing Indigenous employees of the Canadian civil service, it becomes possible to learn how they have perceived their work for the federal government, in what ways they exercised agency at work, and why they did so.

My interviewees employed a variety of measures to navigate their own careers. This became evident as some interviewees revealed meeting with management to communicate their job satisfaction and ability, using applications for alternative new job opportunities across the civil service, and even seeking support from the Public Service Alliance of Canada individually or collectively. Ultimately, some individuals even resigned from the civil service after exhausting other alternatives. Overall, interviewees conveyed how they made careful choices to improve their personal fulfillment, job security, and financial reward within the structures of the civil service. In this section, interview participants have commented on the decisions they made over the years within their individual work trajectories, demonstrating their role as active agents determining their own economic futures.

\footnotetext{
${ }^{56}$ Cathleen D. Cahill, ““An Indian Teacher among Indians,' Native Women as Federal Employees,” Indigenous Women and Work: From Labour to Activism (Urbana: University of Illinois Press, 2012), 211; Scott, Weapons of the Weak, xv-ix.
} 
Eric perceived the federal public service to be highly rewarding in terms of job satisfaction, career mobility and financial return. He began working at the Office of the Superintendent of Financial Institutions (OSFI) in $1988 .{ }^{57} \mathrm{He}$ was asked to write the national actuarial examinations in his first position as Actuarial Assistant. He passed the first one easily but found the second level exam repeatedly difficult to clear. Regretting the amount of personal time sacrificed while studying for these exams, he met with his employer to assess his options. ${ }^{58}$ His employer was very accommodating: Eric was allowed to transfer into a new position as a Pension Analyst at OSFI. ${ }^{59}$ In this position, Eric ensured that pension plans submitted by Revenue Canada met OSFI rules and regulations before funds were dispensed. Some of the files he handled included Indian band pension plans, which he would approve before Revenue Canada and the former Department of Indian and Northern Affairs could release money to Indigenous pension holders. ${ }^{60}$ This was a work assignment more to Eric's taste; he remained a Pension Analyst until 1992 when he experienced a personal conflict. Eric regained a tranquil working environment when he opted to transfer into a new position at the Personal Taxation branch of Revenue Canada. ${ }^{61}$

Eric has negotiated his civil service position over the years to increase his personal satisfaction and his salary. From 1993-1998, he worked with loyalty code statistics - T1 tax

\footnotetext{
${ }^{57}$ This Department was formed in 1987 under the umbrella of the Department of Finance to oversee all Canadian banks, all finances in the Canadian civil service, and ensure that pensions would be disseminated according to Canadian legal and financial requirements. See Office of the Superintendent of Financial Institutions, "About OSFI,” Last Modified 30 April 2014: http://www.osfi-bsif.gc.ca/Eng/osfi-bsif/Pages/default.aspx.

${ }^{58}$ Interview with Eric McGregor, 3.

${ }^{59}$ Eric McGregor, Email Communication, 17 June 2014.

${ }^{60}$ Interview with Eric McGregor, 4.

${ }^{61}$ Ibid., 4.
} 
return statistics according to geographical area. Eric found this post interesting because he was able to combine both of his academic interests: "Statistics I love. Geography I love. You put those two things together...I was really...I was happy there. ${ }^{92}$ When Eric coveted a higher salary in 1998 he accepted a work assignment in the Corporate Taxation Statistics branch as the Acting Research Analyst. ${ }^{63}$ This was not a position he enjoyed and so he asked a contact in the Human Resources branch of INAC to assist him in applying for a statistics position in 1999. He then became an Analyst examining Canadian census data. He has continued to work at INAC up to and beyond the department rebranding in $2011 .{ }^{64}$ Now, he enjoys the position of Senior Analyst. One of his yearly assignments as an Analyst at Aboriginal Affairs has been to prepare statistical data from the Indian register at Aboriginal Affairs and Northern Development Canada. He also answers statistical inquiries on behalf of the department. ${ }^{65}$ Aboriginal Affairs has been an excellent work environment with little to no turnover. ${ }^{66}$ Eric has been satisfied with his salary which has increased over time. He has worked in this section for over fourteen years and intends to remain in his position until his retirement. At this point in his career, Eric claims it is too much of a "risk" to pursue further career progression when he is already content with his career trajectory. ${ }^{67} \mathrm{He}$ has therefore navigated various departments and job descriptions in the civil

\footnotetext{
${ }^{62}$ Ibid., 4.

${ }^{63}$ Ibid., 5.

${ }^{64}$ Aboriginal Affairs and Northern Development Canada, "Change to the Department's Name," Last Modified 31 August 2011: https://www.aadnc-aandc.gc.ca/eng/1314808945787/1314809172051.

${ }^{65}$ Interview with Eric McGregor, 6.

${ }^{66}$ Ibid., 6.

${ }^{67}$ Ibid., 11.
} 
service when he chose to do so and declined when he felt satisfied with his career mobility, workload, and income. ${ }^{68}$

John recalls a gratifying career in the civil service where he was challenged, experienced career mobility and enjoyed the capacity to make decisions at work. He was employed at the Department of Indian and Northern Affairs from 1994-2000 in a variety of positions. ${ }^{69}$ He held a management position in his final year in this department, recruiting and training an Indigenous employee to fill this vacancy before moving on. In 2000, John pursued executive work assignments through the Career Assignment Program. Leaving his position to another Indigenous employee helped to ensure "a legacy of opportunities for other qualified applicants." ${ }^{70}$ In this way, John not only enjoyed the opportunity to move through the ranks of the civil service but was also able to improve the work opportunities available to other Indigenous employees.

As described earlier, John maneuvered through the hierarchy of the civil service by participating in the exclusive CAP. John recalls that although he "was the only Indigenous employee on staff" he "noticed the senior management in this department had great sensitivity." At National Defence, John was given the opportunity to prepare a National Defence tradeshow booth to be displayed at the Assembly of First Nations (AFN) Annual General Assembly Meeting that year. Using the photographic archives at the department, John assembled an exhibit that commemorated Indigenous veterans in Canada. The booth was favourably received by AFN attendees. In his interview, John cited this exhibit as providing useful positive attention for

\footnotetext{
${ }^{68}$ Eric remembers very few conflicts or challenges in his career. The challenge that does stand out for him is his imperfect bilingualism. He can, however, communicate on an acceptable level when answering statistical questions from the public. Ibid., 9 .

${ }^{69}$ Some details regarding John's work experiences have been removed from the thesis to better protect his anonymity.

${ }^{70}$ Due to concerns with anonymity, the narrator of this statement will not be named and the interview transcript it has been taken from will be destroyed at the close of the study.
} 
Indigenous Veterans, but also for the Department of National Defence. This department continued to manage negative perceptions resulting from the 1990 Oka crisis. AFN Chiefs awarded a plaque to the National Defence team for assembling the best tradeshow booth. As the sole Indigenous employee in the department and the organizer of the trade booth, John presented this award to the Deputy Minister of National Defence. ${ }^{71}$

During the remainder of his placement at National Defense John worked in the area of internal communications, disseminating publications and presentations across the department and to military bases in Canada. John held a longer CAP placement at the Treasury Board of Canada Secretariat (TBS). In his interview, John described working for the TBS as “.... an amazing experience in a very busy central agency of government." He perceived TBS to be the most challenging environment because of its central role in the civil service, rather than more specialized departments where he also worked. ${ }^{72}$ The chief responsibility of a Policy Analyst in this department was to prepare Treasury Board Submissions which informed Cabinet on the merits and details of proposed policies or programming for the federal government. Treasury Board Submissions also included detailed summaries of each submission called a précis and talking points for closed camera presentations of submissions. Ministers used this information when presenting new policies to Cabinet in the hopes of receiving the approval and the mandate to enact new initiatives on behalf of their departments. However, Treasury Board Submission work would only be one task assigned to policy analysts. John described the multiple responsibilities included in the work portfolio of a TBS Policy Analyst to include financial

\footnotetext{
${ }^{71}$ Many of these details have not been attributed to their author due to concerns of anonymity.

${ }^{72}$ The Treasury Board of Canada Secretariat was formed in 1867 and traditionally has been responsible for all policy, regulation and programming implementation endorsed by Cabinet. See "About the Treasury Board," Treasury Board of Canada Secretariat, Last Modified 19 December 2007: http://www.tbs-sct.gc.ca/tbs-sct/abuans/tb-ct/abu-ans-eng.asp.
} 
estimates, reports, annual updates and presentations to audit committees. Policy Analysts moreover functioned as contacts for assigned departments, agencies and crown corporations; they answered policy and regulation questions daily and worked with other departments when preparing Treasury Board submissions and budgets. Consequently, multi-tasking, competency and efficiency were all highly emphasized skills in this department. ${ }^{73}$

The chief proficiency John acquired in the civil service, however, was improved writing ability. He told me, "[t]he pressure I underwent in the last six years of employment at the Treasury Board was worth it." This was largely due to his perception of the transferable skills he would gain from this work: "this position helped to hone my ability to write and research. I was also able to gain insight to how government and cabinet really worked." The expertise in research, precision, and writing skills became valuable to John as it later contributed to his personal and cultural interests. These personal activities cannot be expanded on within the thesis due to anonymity, but the recognition of the usefulness of professional skills outside of work did inspire John to continue in federal government employ until 2013.

In regard to advancement, John argued there were no obstacles that affected his career mobility. His salary and promotion were on par with his colleagues in the Career Assignment Program. This continued upon leaving the program and returning to a unionized position. $\mathrm{He}$ attended annual performance reviews in the form of an interview. Each year he attained the level of fully acceptable in these staff evaluations. In one year, however, he was reviewed as exceptional in his performance evaluations. John declared how that "particular year was trying and difficult... and so it was satisfying to have that feedback given." John also perceived fairness in the process in which his colleagues moved through pay categories and ranks of the civil

\footnotetext{
${ }^{73}$ Many of these details have not been attributed to their author due to concerns of anonymity.
} 
service in the 1990s and the early 2000 period. He also admired his coworkers who were highly intelligent and exceptionally devoted individuals. Overall, John was satisfied with his employment with the Canadian federal civil service. He held many opportunities for advancement and salary promotion over the years. His experiences were valuable and pleasant. John posits that his intuition at work may have caused him to have such positive experiences. He could apply to internal government job openings. He did not accept a job opportunity without researching the position, noticing the behaviour of his future colleagues and the general state of the working environment. When John was offered work in departments that appeared chaotic he opted to work elsewhere. In this way, John negotiated his individual role within the hierarchy of the civil service so as to hold positions he would enjoy.

For CQ, he remembers his professional experiences at the Museum of Civilization and at the Department of Canadian Heritage as positive and fascinating because they fell within his area of personal interest. ${ }^{74} \mathrm{He}$ was able to access renowned Indigenous art collections that would otherwise be restricted if he did not work in Canadian national institutions and crown corporations. ${ }^{75} \mathrm{CQ}$ also worked outside of Canada, filling positions as an Assistant Conservator at the National Museum of the American Indian and as a Conservation Intern at the British Museum. He was exposed to famous artifacts such as the Captain Cook collection and other Eastern woodlands material through these placements. Consequently, CQ has been grateful for

\footnotetext{
74 The Canadian Museum of Civilization was rebranded the Museum of Canadian History in 2012. Museum of Canadian History, "The New Museum of History," Last Modified 17 October 2012:

http://www.historymuseum.ca/media/news/the-new-canadian-museum-of-history/.

${ }^{75}$ Interview with Anonymous Civil Servant (CQ), 18 November 2013.
} 
the ability to work in his field of museum conservation and with the opportunity to access Indigenous collections both within Canada and internationally. ${ }^{76}$

In his interview, CQ explained how contributing to the civil service as an Indigenous heritage professional was valuable because he was able to impact the field from a cultural point of view. He wanted to add an Indigenous perspective to the conversation at the Canadian Museum of Civilization where they housed Canadian Indigenous art. The CMC, he insists, was a good employer in that they were sensitive to Indigenous cultural and spiritual concerns in regard to working with the art collections in their possession. CQ participated in the development of the Traditional Care Program at CMC in the aftermath of The Spirit Sings: Artistic Traditions of Canada's First Peoples controversy. In our conversation, CQ remembers the details of this program well:

That was one of the projects that I had helped develop at the Museum of Civilization their traditional care program, which is making arrangements to have elders and other spiritual leaders come into the museum, from different cultural groups at different times of the year according to their respective culture and heritage traditions, doing things like ritual smudgings of the artifacts...making arrangements whereby people would be brought into the museum to do traditional care... on behalf of the sacred or ritual materials in the collection. ${ }^{77}$

In this way, working in the former Canadian Museum of Civilization as an Indigenous employee was satisfying because he could be part of movements toward greater cultural awareness and sensitivity. CQ provided similar input in the Department of Canadian Heritage and has assisted in the planning and management of a wide range of national-scale commemorations.

\footnotetext{
${ }^{76}$ The dates for these various positions have been removed from the thesis due to anonymity. ${ }^{77}$ Ibid.
} 
At the same time, CQ told me he has observed an underrepresentation of Indigenous workers within the Canadian heritage industry during his career. He has contributed to remedying this through his work with the Native Intern Program at the Canadian Museum of Civilization, now known as the ATPMP program. ${ }^{78}$ He was happy to be part of the original selection committee for the ATPMP program in the early 1990s and also to serve as its Chairperson. He places a high importance on cultural inclusivity and equity in national institutions. $^{79}$

Amidst many of these positive benefits, CQ also experienced limitations within the Canadian civil service in regard to career advancement. He began working at the Canadian Museum of Civilization at a time when there was a call for more Indigenous input within museology. However, his work experiences were limited to contract work for over ten years. He maintains that he was the last of his graduating class in Museum Conservation at Algonquin College to receive an offer of permanent employment. Furthermore, the same shift that may have contributed to his employment in museums did not extend to managerial assignments. CQ resigned from $\mathrm{CMC}$ and began working as a Policy Analyst at the Department of Canadian Heritage, a decision he made when job security and promotion were continually unavailable to him at CMC. He had filled the position of Acting Head of the Conservation Section at CMC several times on a rotational basis while the Permanent Head was away on medical leave. He applied to be Permanent Head of Conservation and was denied this post; during his debriefing

\footnotetext{
${ }^{78}$ This program has been renamed to the RBC Indigenous Training Program in Museum Practices. See Canadian Museum of History, "The RBC Indigenous Training Program in Museum Practices," Date Accessed 30 November 2014: http://www.historymuseum.ca/research-and-collections/research/Indigenous-training-program/.

${ }^{79}$ Interview with Anonymous Civil Servant (CQ), 18 November 2013.
} 
interview he was told that he "didn't fit the preferred profile for management at the CMC." 80 CQ views this denial as a systemic issue; not only are there still few Indigenous employees in his particular field, even fewer Indigenous staff reach positions within management. As mentioned earlier, CQ individually negotiated his role in the workplace by improving his educational background to be more highly qualified for future positions; he applied elsewhere for work; and he resigned from the Canadian Museum of Civilization to work for the Department of Canadian Heritage. $^{81}$

CQ also participated actively in the Public Service Alliance of Canada. In 2009, Local 73096 of the Public Service Alliance of Canada went on strike in reaction to a proposed privatization of the War Museum and the Canadian Museum of Civilization. Three quarters of museum staff members were to be severed and rehired through six month contracts to reduce salary and pension expenditures on behalf of the Canadian Museum of Civilization Corporation. ${ }^{82} \mathrm{CQ}$ participated in a four month information picket of the War museum with fellow PSAC members who objected to the removal of their benefits. CQ and other PSAC members were able to rally public opinion in their favour against new policies authorized by the CMC:

For those of us who were doing our picket duty at the War Museum, we were able to frame that in the sense that- the Canadian War Museum is in the process of being privatized. It's not about the money. The strike isn't about the money. Nobody gets into museum work for the money. As the War Museum is being privatized the quality and the caliber of the commemoration that we are able to give to Canada's war dead, to our

\footnotetext{
${ }^{80}$ Ibid.

${ }^{81}$ Almost all of the dates for this section have been removed for anonymity.

${ }^{82}$ Interview with Anonymous Civil Servant (CQ), 18 November 2013; Carlo Fanelli and Priscillia Lefebvre, "The Ottawa and Gatineau Museum Workers' Strike: Precarious Employment and the Public Sector Squeeze," Uniting Struggles: Critical Social Research in Critical Times (Toronto: Red Quill Books: 2011), 129-135.
} 
Veteran's, to our serving members, is being diminished. The people that we were dealing with - the visiting military members, the ordinary members of the general public, Veterans coming in - they really identified with that. ${ }^{83}$

This particular union effort was very successful in preventing the reduction in permanent staff at the War Museum by outlining their job action as a reaction to reduced quality in museum services and commemoration. The strike helped to protect permanent positions for workers. However, it may have impacted CQ's career mobility as an individual. CQ applied to be Permanent Head of the Conservation and Collections Management Section at the Canadian Museum of Civilization. He had experience within this role as Acting Head of this section periodically while the current head negotiated a medical leave. In the wake of the 2009 PSAC strike, however, CQ acknowledged that he "already had a reputation for being heavily involved with the union issues and Native issues." ${ }^{\prime 4} \mathrm{CQ}$ suspects that this affiliation may have limited his career development: "[p]resumably as a function of my history of union involvement and speaking out on Native issues and that kind of thing I didn't strike them as being the kind of personality who would be willing to side with management over whatever other issues that were being brought forward. ${ }^{, 85} \mathrm{CQ}$ suspects that his active participation in union work may therefore have limited his promotion and advancement opportunities.

In her interview, Ronda Evans described how she enjoyed working for the federal government during the early portion of her career but perceived this environment to be less rewarding over time. Ronda had moved between administrative contracts and had steadily been

\footnotetext{
${ }^{83}$ Interview with Anonymous Civil Servant (CQ), 18 November 2013.

${ }^{84}$ Ibid.

${ }^{85}$ Ibid.
} 
working towards a position where she would work more directly with communities. In 1994, a colleague notified her that Health Canada was looking for an Indigenous employee to run a new program to be called the Aboriginal Head Start Program. This initiative officially launched in 1995 on a national level and Ronda worked as its Program Assistant from 1994 to $2013 .{ }^{86}$ Its purpose was to better prepare Indigenous children for school and to do so with the cooperation and input of both parents and their communities. ${ }^{87}$ Ronda recalls: "it was just very different from other programs because it involved the people who were most affected - and by that I mean the parents of children who would be attending. ${ }^{88}$ Furthermore the program was oriented from the 'ground-up' because “it involved them in very meaningful ways - decision making roles at all levels of the program, be that at their local level, at the regional level, and at the national level." ${ }^{89}$ Ronda was thrilled to accept the position because she had been following the development of this program in the media and strongly approved of its grassroots foundation.

Ronda perceived her own role in the program to be one of guidance. Ronda argues that the Aboriginal Head Start program was originally intended to be temporarily run with the partnership of the Canadian government; it would eventually devolve to regional communities where programs were centred. ${ }^{90}$ She believed that her work was merely to assist communities toward this goal. Ronda went beyond her job description in that she not only managed Ontario programs she also prepared training packages so that regional community centres could work

\footnotetext{
${ }^{86}$ Health Canada, "Indigenous Head Start on Reserve,” Last Modified 15 June 2011: http://www.hc-sc.gc.ca/fniahspnia/famil/develop/ahsor-papa intro-eng.php.

${ }^{87}$ Ibid.

${ }^{88}$ Interview with Ronda Evans, 31 January 2014, 6.

${ }^{89}$ Interview with Ronda Evans, 6.

${ }^{90}$ Ibid, 12.
} 
independently without her assistance. Part of this work included the creation of instructional packages troubleshooting common problems within community programs and also training programs for future staff. ${ }^{91}$ The program also grew over time and Ronda was no longer the only facilitator for the program. Indigenous employees were hired onto the program to work with and for Indigenous communities in addition to the single Indigenous Program Consultant assigned previously. ${ }^{92}$

Ronda claims the vision and delivery of the Aboriginal Head Start Program was highly affected by the change in federal mandate with the election of the Conservative Party in 2006. Specifically, she told me that the Aboriginal Head Start Program became increasingly centralized instead of moving toward community ownership and facilitation. ${ }^{93}$ Previously there had existed national working groups as well as the opportunity for regional input into programming at national meetings of the Aboriginal Head Start program; these efforts were disbanded in the later portion of Ronda's career. ${ }^{94}$ By 2009 , Ronda paints her working environment as one where they were "working in silos" and where they, as program facilitators, would be unexpectedly "blindsided with a new approach or a new decision on how things were going to happen." 95 Ronda consequently grew increasingly uncomfortable with this shift in programming direction.

By 2011, Ronda felt her employment to come into blatant conflict with her values as an Indigenous employee and community advocate. At a national meeting in 2011, the new budget

\footnotetext{
${ }^{91}$ Ibid., 6-7.

${ }^{92}$ Ibid., 7-8.

${ }^{93}$ Ibid., 12-13.

${ }^{94}$ Ibid., 8.

${ }^{95}$ Ibid, 8.
} 
for the Aboriginal Head Start Program was announced to be five million dollars. Unfortunately, two million of those dollars were assigned to be utilized by the federal government as a fee to administer the program. Ronda was shocked by this announcement and questioned officials as to how they could rationalize such an inflated administration fee. ${ }^{96}$ As a Program Consultant she was not in a position to alter these financial decisions. Ronda chose to remain in what she felt to be a difficult work environment because she feared for the future of regional programs should she resign. As she recalled to me, Ronda was passionate about her work and felt she was able to better help communities by remaining in her position. ${ }^{97}$ In 2012, 19200 federal civil service positions were eliminated in order to increase efficiency and reduce expenditures in the Canadian civil service. ${ }^{98}$ In 2012, Ronda consequently decided to write a history of the Aboriginal Head Start Program, opted to become a surplus employee, and trained her replacement at this time. ${ }^{99}$ By opting to become surplus, Ronda's duties were transferred to coworkers and she continued working full-time hours for a limited time before her position was dissolved. ${ }^{100}$ She retired at fifty-five, insisting to me that she chose to move on to retirement with "no regrets!"101 Overall, Ronda was very passionate about her work in the civil service. She viewed it as highly necessary

\footnotetext{
${ }^{96}$ Ibid., 8-9.

${ }^{97}$ Ibid., 9.

${ }^{98}$ Ibid., 9; See CBC News, “Budget Cuts 19000 public service jobs,” Last Modified 29 March 2012: http://www.cbc.ca/news/politics/budget-cuts-19-000-public-service-jobs-1.1170727
}

${ }^{99}$ Interview with Ronda Evans, 9.

${ }^{100}$ Ronda Evans, Email Communication, 20 May 2014; The Professional Institute of the Public Service Alliance of Canada, "Work Force Adjustment Affected and Surplus Status," Date Accessed 20 June 2014: http://www.pipsc.ca/portal/page/portal/website/issues/wfa/faqs.

\footnotetext{
${ }^{101}$ Interview with Ronda Evans, 9; this history of the Aboriginal Head Start Program would be internal to Health Canada and now available to the public.
} 
social programming for Indigenous families and rewarding work for Indigenous employees engaging with the project on a national and regional level.

In addition to competing visions, Ronda had a personal conflict with one of her managers while being employed at Health Canada. This particular manager encouraged her to purchase counterfeit merchandise from a flea market stall he owned. He was eventually charged with fraud. Ronda became a crown witness during this investigation. Her manager continued to receive the support of the department throughout these events much to Ronda's surprise and dismay. She challenged this as she felt it was unethical for a manager to have signing authority over Indigenous programs when on trial for fraud. Ronda recalls that her manager began harassing her at this time. ${ }^{102}$ She complained about this treatment to human resources and asked to be separated. This request was denied and she went on stress leave for a six months period. The manager, Ronda told me, was eventually convicted of fraud and was let go from the civil service. Ronda returned to work at this time and also became a Public Service Alliance of Canada union representative for harassment claims. She was able to regain her stress leave time and help many other harassment victims achieve similar restitution. In her interview, Ronda explained that the union could successfully pursue harassment cases to achieve a settlement for the victim. However, this settlement was usually of a financial nature and an apology or acknowledgement of harassment was never possible to be obtained. ${ }^{103}$

Ronda's experiences were unique in some ways but they also reflected a wider pattern among interviewees with respect to their ability to negotiate the labyrinth-like structures of the bureaucracy and its human resource practices. She actively defended her rights as a worker,

\footnotetext{
${ }^{102}$ Ibid., 13.

${ }^{103}$ Ibid., 15.
} 
consulted her union during a case of harassment, utilized a leave of absence when she disagreed with her treatment during a grievance at work, and became an advocate for other harassment victims in the civil service when her grievance was successfully resolved. In a final expression of agency, Ronda chose to retire from her position when the nature of the program changed in a way that alienated Indigenous communities from participation in the decision making processes of the Aboriginal Head Start Program

Dave Monture worked in the Canadian civil service between 1969 and 1980, a time he observed Indigenous employees to be a minority, especially in the early years of his civil service career. In 1969, Dave claims there were so few Indigenous people working at the Department of Indian and Northern Affairs that they were even viewed as "curiosities" that could be "count[ed] on two hands." 104 He was recruited into the department in 1969 to assist in the Press Clipping Service. In his interview, he recalled that efforts to hire Indigenous employees into the civil service existed. ${ }^{105}$ What he likely had recalled was the Indian Placement and Relocation Programme that began in 1957 and lasted throughout the 1960s, selecting Indigenous workers from across the country to work in urban occupational centres, including in Ottawa within the federal civil service. ${ }^{106}$ A second program in existence during this period was the Indian Eskimo Recruitment Program which was initiated in 1969 within the Department of Indian and Northern Affairs specifically as a placement and career development initiative. ${ }^{107}$ Dave remembers also how a large number of senior employees at this time had been hired through the Veteran's

\footnotetext{
${ }^{104}$ Interview with Dave Monture, 29 December 2013, 4.

105 Ibid., 3.

${ }^{106}$ Department of Citizenship and Immigration, Report of the Indian Affairs Branch, 1960, 47.

107 “INAC Indian Eskimo Recruitment Program,” The Indian News, Vol. 12, No. 1 (April 1969), 1-5.
} 
preference. They continued to fill a large number of positions in the late $1960 \mathrm{~s} .{ }^{108} \mathrm{He}$ remembers his coworkers as good people to work with. He was supported by managers, worked independently, and argued that he never needed to integrate into the civil service's mainstream culture during his employment. ${ }^{109}$

Dave maintained that the work experience he gained in the Canadian federal public service was very helpful in that it provided educational and career development opportunities. He states: "I would say I took more out of it than it took out of me." ${ }^{110}$ Dave learned from experience. He kept up to date on issues of national importance in the Record, Research and Clippings Section of the Department of Indian and Northern Affairs, including media topics such as the 1969 White Paper Policy and the reaction of Indigenous communities to this proposed federal assimilation legislation. ${ }^{111}$ As an Assistant Editor of The Indian News -and later as the Editor- Dave interviewed and networked with Indian political leaders including Harold Cardinal and George Manuel. Dave revealed in his interview how he believed the high quality of media coverage he encouraged increased the prestige of the departmental newsletter. ${ }^{112}$ Working in journalism also exposed Dave to career opportunities with the National Indian Brotherhood (later the AFN), under President George Manuel. He later gained the opportunity to work for the Assembly of First Nations, The Indians of Quebec Association, Indigenous Survival

\footnotetext{
${ }^{108}$ Interview with Dave Monture, 3; Veterans were the first group in Canada to be given preferential hire into the federal government. This policy began with the Civil Service Act of 1918 (at the cessation of the First World War) and lasted until the 1960s. See Luc Juillet and Ken Rasmussen, Defending a Contested Ideal: Merit and the PSC of Canada 1908-2008 (Ottawa: University of Ottawa Press, 2008), 50-57.

${ }^{109}$ Interview with Dave Monture, 3.

${ }^{110}$ Interview with Dave Monture, 11.

${ }^{111}$ Ibid., 4.

${ }^{112}$ Ibid., 4.
} 
International, the Council of the Haida Nation, and the Massett Village Council. Through working in the civil service, however, Dave was able to observe how goals like equity could be conceptualized and moved through the public service to become actionable policies. He believed these insights made him a better external community representative working with government on behalf of Indigenous communities.

Dave was recruited first as the Ontario Coordinator of the Office of Native Employment in Toronto in 1974, becoming their National Coordinator eighteen months later. ${ }^{113}$ This office was formed as part of the larger Public Service Commission in 1974. In its Annual Report, the Public Service Commission announced that this branch would be responsible for surveying statistics on First Nation, Métis and Inuit employment across the civil service. They had many responsibilities, including recruiting Indigenous university students across Canada, tracking the career mobility of target group employees in the federal government, and encouraging Indigenous communities to contribute to staffing efforts within their purview. ${ }^{114}$ In his interview, Dave claims he was not just a Program Coordinator; he travelled extensively across Canada to interview and refer Indigenous candidates to positions in the civil service. ${ }^{115}$ In the Office of Native Employment, Dave was involved in the implementation of equity programming.

Looking back on his years in the civil service, Dave believes that positive change and awareness could be successfully launched within government by moving the civil service forward on social issues from outside government. He learned that Departmental Ministers were more useful for public relation opportunities than for any role they might play in policy

\footnotetext{
${ }^{113}$ Ibid., 4-5.

${ }^{114}$ Public Service Commission, Annual Report, 1974, 28.

${ }^{115}$ Interview with Dave Monture, 6.
} 
decisions. In the background, Dave told me, "the real work and the real policy efforts [were] undertaken by pretty well educated public servants." ${ }^{116}$ Moreover, working with these senior officials was more productive personally than when working with middle management. ${ }^{117}$ As an outside consultant, however, Dave could move past middle management and work directly with senior public servants. In one particular case, Dave recalls securing a 2003-2004 meeting with Alex Himelfarb, then the Clerk of the Privy Council (the most senior public servant responsible to Cabinet and responsible for the public service as a whole). As an outside consultant for the Shuswap Band in British Columbia, Dave was able to discuss funding delays directly with decision makers. Specifically, he initiated a conversation around Indigenous language preservation in Canada and the Department of Indian Affairs and Northern Development's failure to address the Skeethest'n Band land designation. ${ }^{118}$ Dave recalls this meeting with fond success, having resolved the issue within a matter of days after bringing it to the appropriate authorities. ${ }^{119}$ This was preferable, because, Dave remembers working with the civil service as an external advocate for Indigenous communities was far more productive than when he tried to do so as a civil servant enmeshed within the bureaucratic hierarchy. This memory is so strong that Dave is featuring it in a fictional novel he has been writing since 2011, The Journals of the Pinetree Chief. ${ }^{120}$

The Canadian federal public service is a privileged, highly qualified and educated portion of the Canadian workforce. Employees may take advantage of many benefits including but not

\footnotetext{
${ }^{116}$ Ibid., 5.

${ }^{117}$ Ibid., 5 and 12.

${ }^{118}$ Ibid., 8.

${ }^{119}$ Ibid., 8.

${ }^{120}$ Ibid., 9.
} 
limited to maternity or parental leave, stress leave, education leave, pensions, early retirement, and internal civil service job competitions. These benefits did not materialize without the advocacy roles played by workers, both individually and collectively, traces of which we hear from the stories told in this section. While conflict and resolution were one way to affect change, and to exercise agency, the process of negotiating with their employers was often more nuanced: they met with their managers to comment on their job satisfaction; applied for open and internal job competitions; and chose to remain in departments/work assignments where they felt fulfilled. Similarly, they worked individually and/or collectively with their human resource agencies and their unions, and even resigned (or retired) from positions when they were dissatisfied.

\section{Identity Maintenance}

CQ associated his work at the former Canadian Museum of Civilization and the Department of Canadian Heritage very closely with his identity as a Delaware person. CQ was hired through the targeted National Indigenous Development Program of the Public Service Commission and so was very conscious that being Indigenous contributed to his employment. Also, he joined the museum and heritage field in order to contribute to these discussions in museology as a First Nation individual. He clearly identified himself as "a Native expert on Native issues with a particular focus on Indigenous culture, heritage and language matter." ${ }^{121}$ In his interview, CQ made clear to me that he views his own work, and that of other Indigenous employees, as especially important in heritage government institutions and policy work because he continues to view Indigenous museum professionals as underrepresented in these areas. CQ goes even further:

\footnotetext{
${ }^{121}$ Interview with Anonymous Civil Servant (CQ), 18 November 2013.
} 
The federal government is going to continue to make rules and regulations about Native people whether Native people are in the room or not. In fact it's my own perspective that the onus is on Native people to ensure that we are working within the federal government to provide a Native perspective, and if nothing else, to provide some sort of an oversight function that otherwise would be lacking. ${ }^{122}$

CQ has therefore perceived a very clear purpose in his lifelong career, one that he perceives as an obligation. Government structures hold the power to craft and enact policies regarding the cultural and artistic heritage of his community. He has therefore intended to be part of the process; his role has therefore become both that of a helpful subject matter expert as well as a cultural representative in government protecting the interests of his community.

John worked for the federal government from the late 1990s until the early 2010s and has only occasionally associated his work position with his Odawa identity. As a young Carleton MA student, John completed an internship at INAC in cultural programming where he felt his Indigenous background to be culturally and linguistically essential. ${ }^{123} \mathrm{He}$ also helped build a tradeshow exhibit showcasing Indigenous Veterans for the Assembly of First Nations Annual Meeting while working at National Defence. In this position John acknowledged that an understanding of historical and contemporary Indigenous history and political debates were especially important. ${ }^{124}$ However, John did not associate his work with his cultural identity when he was positioned at the Treasury Board Secretariat. Here, he was responsible for a variety of assignments which often were unrelated to his personal background - such as the Status of Women file he oversaw for six years. Far from viewing race to be an important element of his

\footnotetext{
${ }^{122}$ Ibid.

${ }^{123}$ Interview with Anonymous Civil Servant (John), 18 November 2014.

${ }^{124}$ Ibid.
} 
job at Treasury Board, John perceived employees to be "hired for merit and intelligence." 125 Furthermore, he perceived this to be rightly so as the federal civil service should serve all Canadians. He therefore did not see why his cultural identity should affect non-cultural work in government or why federal employment should alter his personal identity outside the workplace.

John was also a union representative while at INAC and was aware of both legitimate racial discrimination and complaints which were less credible. ${ }^{126}$ Personally he did not suffer any intentional discrimination, "only some funny situations with colleagues which were not hurtful. ${ }^{127}$ Instead, John considered the civil service to be very sensitive to the cultural backgrounds of their employees since the late 1990s. While working at INAC, John had access to the Kumik Lodge where he could meet with spiritual elders or attend cultural workshops. John remembers cultural awareness days to take place at the Treasury Board Secretariat and across the federal government. Consequently, John perceived cultural awareness to have been "very visible in the civil service." 128

Race was nevertheless a factor in John's overall career as he was hired into the Treasury Board Secretariat through a special call for Indigenous candidates in the Career Assignment Program. Part of the reasoning for this gap between work and identity in John's interview, however, emerged through learning how deeply John has associated his identity with personal interests which have been external to government. John perceived the civil service to be a helpful developmental phase in his life but not to be central to his identity. Instead, his identity has been

\footnotetext{
${ }^{125}$ Ibid.

${ }^{126}$ Interview with Anonymous Civil Servant (John), 18 November 2014.

${ }^{127}$ Ibid.

${ }^{128}$ Ibid.
} 
associated with his cultural interests away from the job. He has been a very active presence within his cultural community. He previously taught Indigenous students at Laurentian University when still an MA student, and he still devotes time to teaching Indigenous youth in Ottawa informally and in creative ways but this has not been on a full time basis. Furthermore, John now considers himself to be a part of an urban community of Indigenous peoples in Ottawa. ${ }^{129} \mathrm{He}$ has maintained a cooperative relationship with researchers from universities and has been a helpful participant for me in the Remembering the Civil Service Study. In our time together, John was clear that he has put his civil service career behind him and that his identity is fully enveloped within community work. He wishes to remain anonymous due to these activities.

Dave Monture similarly did not consider his work as a public servant to be closely associated with his identity. He held various positions in the civil service between 1969 and 1981, and during this time, Dave argues he had individual freedom and did not believe he was "integrated." ${ }^{130}$ However, toward the end of his civil service career Dave considered himself to be in tension with his work environment. As he personally grew up on an Indigenous reserve and lived there until the age of eighteen, Monture felt unimpressed that so few people in the public service and at the Department of Indian Affairs and Northern Development in particular, could become senior policy makers without visiting the reserve communities for which they set policy. ${ }^{131}$ From 1980-1981, Dave claims he was at odds with senior officials at the Department of Indian and Northern Affairs: "I felt I was in conflict, policy-wise, with what they thought they

\footnotetext{
${ }^{129}$ Ibid.

${ }^{130}$ Interview with Dave Monture, 3.

${ }^{131}$ Ibid., 7; Dave Monture, Telephone Communication, 06 June 2014.
} 
were doing." 132 This was an especially stressful time considering how the Charter of Rights and Freedoms was drafted in 1981 and excluded any Indigenous recognition. ${ }^{133}$ In the early portion of his career, Monture recalls how well-educated public servants rose through the ranks of INAC as long as they had portable skills and education in public policy. ${ }^{134}$ Dave consequently left the federal government and began working for the Assembly of First Nations. ${ }^{135}$ He has continued his independent consulting work from 1981 to the present, working directly for Indigenous bands and communities. Consequently, the civil service was a very useful career development opportunity that prepared him for the community work and advocacy efforts he undertook in his later career. ${ }^{136}$ However, he has not closely identified these experiences with who he is in the present.

Instead, Dave has aligned his identity with his kin community and with his cultural work regardless of where he has resided or laboured. The Canadian federal public service was his employer during the first twenty years of his working life but he has since moved on. Dave's novel, The Journals of the Pinetree Chief, has employed his observations of the Canadian federal government to speak to the political efforts of the Six Nations people and their experiences of decolonization. ${ }^{137} \mathrm{He}$ has also worked full time as the Technical Assistant Specialist for Alaska

\footnotetext{
${ }^{132}$ Ibid., 7.

${ }^{133}$ J. R. Miller, Skyscrapers Hide the Heavens, 239.

${ }^{134}$ Interview with Dave Monture, 7; Dave Monture, Telephone Communication, 06 June 2014.

${ }^{135}$ Interview with Dave Monture, 7; Dave Monture, Telephone Communication, 05 May, 2014; The National Indian Brotherhood transformed into the Assembly of First Nations in 1982. Their rebranded namesake made a powerful statement regarding their equality with the Government of Canada on an international stage and the treatment they expected within such a relationship.

${ }^{136}$ Interview with Dave Monture, 9.

${ }^{137}$ Ibid., 10-11.
} 
at the Intertribal Agricultural Council Technical Assistance Program since 2012. In this position he has been responsible for the environmental conservation and food security of the Inuit, Aleut and Alutiiq speaking peoples on the coastline of Alaska. ${ }^{138}$ His identity, however, remains with his home community of the Grand River Reserve in Brantford, Ontario; it has, he told me, remained constant over the years:

[W] hen you grow up on an Indian reserve... with many proud traditions and still four longhouses on the reserve back home, when your children are named in the longhouse, and your parents are Mohawk people, you pretty much know who you are...I never had problems personally because I [have always known] who I was.

Dave has been very mobile throughout his life but has kept in close touch with his family and friends still living in his home community. His preferred method of communicating with family -especially youth - is via Facebook. ${ }^{139}$ Dave has therefore grounded himself in his family ties and in his physical and literary work for Indigenous communities in North America.

Eric McGregor has always been aware of his identity as an Anishinaabe person at work but does not feel that his cultural identity has been essential to each job description he has held. He was definitely aware that targeted employment equity programs were responsible for his being hired into the federal government. He was recruited through the National Indigenous Development Program in 1986, working actively with Indigenous Placement Officers of the Public Service Commission to gain access to this employment. ${ }^{140}$ Eric remembers that the Office of the Superintendent of Financial Institutions "brought [him] in with a lot of fanfare." ${ }^{141}$ In

\footnotetext{
${ }^{138}$ Interview with Dave Monture, 13; Dave Monture, Telephone Communication, 11 April 2014.

${ }^{139}$ Interview with Dave Monture, 11.

${ }^{140}$ Interview with Eric McGregor, 2-3.

${ }^{141}$ Ibid., 4.
} 
1993, he then transferred to the Personal Taxation Branch of Revenue Canada under Monica Weise, a manager who he argued was very enthusiastic about diversifying her department culturally. ${ }^{142}$ In fact, Eric adds that he was skeptical of Weise's recruitment of Indigenous youth into the department. Under her direction, Eric travelled to reserves to recruit Quebec high school students who were only 16-17 years of age in their senior year. This was a concern as training might be more time consuming. ${ }^{143}$ He later added that the students worked out very well. ${ }^{144}$ Eric has worked with Indigenous statistics and census data over the years. ${ }^{145}$ However, his identity has been more closely associated with his trade as a statistician than as an Anishinaabe federal employee. Upon deeper reflection, Eric claimed this was likely because his work did not involve his cultural community in programming or policy development. Instead he has worked in the interpretation of numbers as a statistician. ${ }^{146} \mathrm{He}$ has been aware of his Indigeneity as one among many Indigenous employees at Aboriginal Affairs and Northern Development Canada. However, he has largely considered himself to be "just one of the gang." ${ }^{147}$ In this way, Eric has not closely associated his cultural background with his perception of himself as an employee. If Eric's racial background had been attributed to his economic identity in any way it has largely been due to outside individuals viewing, hiring, and assigning work to Eric on the basis of being Anishinaabe.

\footnotetext{
${ }^{142}$ Ibid., 4; Eric McGregor, email correspondence, 14 January 2014.

${ }^{143}$ Interview with Eric McGregor, 9.

${ }^{144}$ Ibid., 9; Eric McGregor, email correspondence, 25 January 2014.

${ }^{145}$ Interview with Eric McGregor, 6-7.

${ }^{146}$ Eric McGregor, Personal Communication 30 November 2014.

${ }^{147}$ Interview with Eric McGregor, 9.
} 
Eric McGregor has nevertheless encountered situations where race has become an issue of tolerance or discrimination in the workplace. In 1998, he attended a Revenue Canada training workshop in Gatineau. During one of the lunch sessions an employee shared a racist joke stereotyping Kitigan Zibi community members. Following the joke, the individual began dancing in a circle and chanting, pantomiming his perception of an "Indian." ${ }^{148}$ Eric McGregor has been highly attached to his home community of Kitigan Zibi, visiting every weekend during his years at CEGEP, Carleton University, and even maintaining various sport and recreational activities there in the present. His family and friends have continued to live on this reserve, his father and brother both representing the community as Chiefs during various periods. ${ }^{149}$ Needless to say, Eric was shocked that such a comment might be made with reference to his community. $\mathrm{He}$ confronted the individual and felt conflicted about reporting the incident. The individual was apologetic and this did not become necessary. ${ }^{150}$ Overall, this was the only incident that Eric felt to be discriminatory or in bad taste on the part of one individual. He told me that while he encountered many jokes from colleagues, he considered them to be harmless and by people from whom he did not take offense.

In fact, overall, Eric has positive memories of being on the job. For example, he made clear to me that he was very aware of the presence of the Kumik Lodge located at Aboriginal Affairs and Northern Development Canada. ${ }^{151}$ He held discussions with colleagues regarding how this

\footnotetext{
${ }^{148}$ Interview with Eric McGregor, 5.

${ }^{149}$ Ibid., 11.

${ }^{150}$ Ibid., 5.

${ }^{151}$ The Kumik Lodge was formed in 1990 at the Department of Indian and Northern Affairs Canada to provide cultural awareness, training and support for Indigenous employees. See Aboriginal Affairs and Northern Development Canada, “Kumik - Council of Elders,' Last Modified 15 September 2010: https://www.aadncaandc.gc.ca/eng/1100100013748/1100100013749.
} 
centre was helpful to colleagues who received counselling from elders on site. ${ }^{152}$ Eric also received the support of management across the board who allowed him to use vacation days to attend events of cultural importance to him. ${ }^{153}$ In this way, Eric has rarely faced discrimination at work. When in a situation in which this did occur, Eric felt comfortable confronting the offending person with the knowledge that he had the ability to report such an incident to management who would be proactive in dealing with such reports. Furthermore, Eric tells me he was aware of the many ways the civil service on the whole was striving to be a sensitive workplace for Indigenous employees since he was hired in the 1990s. Interestingly, Eric has framed his one memory of discrimination at Revenue Canada within many positive experiences of cultural solidarity and tolerance. He has therefore de-emphasized the impact of this experience on his career. In general, Eric rarely has felt the need to consider his cultural identity in relation to his workplace at all as he has not perceived it to heavily affect the type of work he has pursued.

Ronda Evans has perhaps been the individual who has most closely allied her identity as public servant with that of an Algonquian woman and of a mother. She was the Program Consultant for Health Canada's Aboriginal Head Start Program from 1994 to 2012. Moreover, she was the sole contact running the Ontario Aboriginal Head Start Programs during her first year in this position. In her interview, Ronda described how thrilled she was to be part of this programming initiative: "I remember lamenting how wonderful it would have been if we could have participated in a program like that as youngsters." ${ }^{154}$ Ronda also appreciated how the

\footnotetext{
$\overline{{ }^{152} \text { Interview with Eric McGregor, } 10 .}$

${ }^{153}$ Ibid., 10.

${ }^{154}$ Interview with Ronda Evans, 6.
} 
majority of Head Start staff members were "Indigenous people helping Indigenous people so it was just wonderful." ${ }^{155}$ During her interview, Ronda became emotional as she explained how deeply she regretted the lack of such an initiative when she was a pregnant young woman, unable to raise her child in a stable family home. ${ }^{156}$ Such a program would have been useful in her earlier life. In this way, Ronda has identified her economic identity as a community worker fairly closely with her identity as a woman, a mother, and as an Indigenous person. It was therefore a difficult decision for Ronda to opt to become a surplus employee and leave the Aboriginal Head Start Program in 2012. ${ }^{157}$

Ronda made the decision to become surplus and to retire from the civil service when her working environment came into tension with her values and identity as a community worker. Ronda remembers that even in the early years of the program she was given a high workload with very little assistance. She continued because she found the work fulfilling. Nevertheless, she recalls how she "was just run ragged." ${ }^{158}$ When the program expanded, Ronda was pleased that Indigenous employees were recruited into new positions within Head Start circles to assist with these developments. Looking back on this period, Ronda considered their team to have faced a certain level of discrimination:

I certainly felt at certain points that our Aboriginal team was under resourced compared to the other teams - just based on the number of our projects and the type of work that we were doing, the uniqueness of the work... which the other sections weren't. I felt we had an awful lot on our plate and we had to be criticized for not really participating a lot in the in-house committees and stuff like that... At one point we had two different people

\footnotetext{
${ }^{155}$ Ibid., 7-8.

${ }^{156}$ Ibid., 12.

${ }^{157}$ Ibid., 9.

${ }^{158}$ Ibid., 7.
} 
who had left to go to other jobs and it took [Health Canada] over two years to replace those people so the two of us that were left were doing the job of four people... I mean you don't want to point the finger and say that's because of racism, but it just definitely seemed like it was a low priority in terms of staffing. ${ }^{159}$

In this way, the Aboriginal Head Start Program was innovative in that it worked to improve the education available to Indigenous communities. The program also resulted in the creation of jobs for Indigenous workers in the federal government. According to Ronda, however, the position demanded a great deal of attention, tasking employees to work beyond the general facilitation of programs. They were criticized for not attending in-house committees of the civil service when time constraints in administrating the program did not make this possible. She also considered the appointment or replacement of staff members to take an unacceptable amount of time to complete. Ronda emphasized that she would have been sympathetic in this situation if a similar exertion were made to hire staff for their team as for non-Indigenous teams. In her recollection, this was unfortunately not the case. ${ }^{160}$

\section{Conclusion: Class Formation and Life Stories}

In listening to the stories featured in this chapter, I have been drawn to how research participants have situated themselves as individuals with a unique relationship to the same federal state for which they also worked. Interviewees have varied in the degree to which they have attributed importance (or lack thereof) to their racial background as a factor affecting their experiences at work. In this way, Indigenous civil servants in the study have not displayed a unified class consciousness.

\footnotetext{
${ }^{159}$ Ibid., 15.

${ }^{160}$ Ibid. 15.
} 
Instead, the work experience of each narrator has been subjectively based on the specific context in which they each lived and worked. The only factors uniting interviewees were their decisions to have worked in the wage economy and to be employed by the Canadian federal civil service at some point of their lives. At times their employment was the result of race-specific recruitment initiatives, but at other moments in the study interviewees were hired based upon their individual initiative in applying for open competitions. Some interviewees associated their workplace identity and their cultural identity very closely together due to the nature of their job descriptions as being civil servants working with or for their cultural community. CQ, Dave and Ronda identified this theme strongly in their interviews. For others, however, the character of their work was perceived to be unrelated and entirely separate from their cultural identity. Consequently, interviewees like Eric and John may not have perceived themselves primarily to be Indigenous civil servants. On the contrary, their interviews spoke more strongly to an economic identification with the work of other statisticians or policy analysts working for the federal government. Their cultural identity was not lost by this fact, but rather tied separately to their communities.

Nevertheless, through listening to the details of each life, it has usually been possible to pinpoint moments in which interviewees have been viewed through the lens of their Indigeneity. This can be seen through descriptions of being selectively hired, assigned work, promoted, or having been discriminated against based on race. Consequently, studying the race-based relationship between Indigenous employees and their employers has demonstrated an important aspect of the working life of each individual. 


\section{Chapter Four}

\section{The Life Narrative(s) of Jaime Koebel}

Chapter Three compared the working lives of several interviewees simultaneously. This allowed for a more comprehensive perspective regarding the experiences of each worker in the civil service, their perceptions of the federal government as an employer, and the cultural and economic elements of their identities as civil servants. Methodologically, it offered an amalgamation of oral history narratives. Although this revealed shared life experiences and narratives, such an approach (looking for commonality) also delimited the possibilities of learning from each interviewee. Each life story collected offers a wealth of valuable information that often defied generalization. In contrast to Chapter Three, I now want to demonstrate what we can learn when we allow the entirety of a single life story to frame a history of work.

This chapter examines the life story of Jaime Koebel, which she shared with me in 2013. It explores the personal meaning work has held for Jaime, by situating the relative importance of work experiences within her life and with respect to her sense of self. Interestingly, Jaime previously wrote and published a memoir about her life as a Métis woman in $2007 .{ }^{1}$ This has presented a unique opportunity to also investigate the way people construct their stories for others. Through a comparative analysis of Jaime's oral life story and memoir it has been possible to highlight how Jaime's life stories have changed over time depending on the context and the form of the telling.

\footnotetext{
${ }^{1}$ Jaime Koebel, "My Story: Reflections on Growing Up in Lac la Biche," in Ute Lischke and David T. McNab, eds., The Long Journey of a Forgotten People: Métis Identities and Family Histories, (Waterloo, Ontario: Wilfrid Laurier University Press, 2007): 349-376.
} 


\section{Interview Context}

Jaime Koebel emailed me on Friday 04 October 2013, responding to an advertisement in Minwàdjimowin, the newsletter disseminated by the Aboriginal Centre at Carleton University. ${ }^{2}$ She was a graduate of Carleton (Bachelor of Arts, 2004). Her first email informed me that she had circulated my project information to several individuals in her acquaintance. She also asked to be part of the study even if she did not work immediately within the civil service but instead for a crown corporation (the National Gallery of Canada). ${ }^{3}$ Having some latitude on my project, I immediately replied yes. I was thrilled to have someone solicit me to participate in the study instead of the other way around. Jaime surprised me by sending an advanced copy of the answers she was considering for the questions I had pre-circulated before the interview. In this initial glimpse into her life story I began to see how the arts formed a central part of her life. She identified herself as having had many different work experiences throughout her career while concurrently pursuing her work as a visual and performing artist. ${ }^{4}$ Her time in the National Gallery of Canada would only be one chapter of her story.

In her initial responses, Jaime described how working on the Sakahán exhibit at the National Gallery of Canada was deeply meaningful to her because she was able to use her position as Sakahán Educator to reach both Indigenous and non-Indigenous viewers at the

\footnotetext{
${ }^{2}$ The newsletter for the Indigenous community at Carleton University is titled Minwàdjimowin. See the Centre for Aboriginal Culture and Education (CACE), "Pîjashig! Welcome!” Date Accessed 01 February 2014: http://carleton.ca/aboriginal/.

${ }^{3}$ Jaime Koebel, Email Communication, 04 October 2013.

${ }^{4}$ Jaime Koebel, Email Communication, 12 October 2013.
} 
Gallery. ${ }^{5}$ Jaime explained: "I saw that my role as an educator when I educated Non- Aboriginal people was a service to the Aboriginal community and when I educated the Aboriginal community - it was a service to them as well. In the overall picture of course, I understand that educating people through art is in the best interest of Canadian society as a whole." ${ }^{6}$ In this way Jaime capitalized on the interest in Indigenous art to raise awareness in the Canadian public about contemporary and historic issues faced by Indigenous communities in Canada. Jaime recalled: "I got to meet a lot of amazing Indigenous artists, I got to talk about my personal experiences from my whole past, everything from homelessness issues, to the time of learning about...my grandmother who was murdered at the age of 34 years old...this whole summer I was 34 years old." 7 Jaime took a personal approach to her work, using artistic depictions of Indigenous women and their experiences in Canada to speak about her personal experiences as well as those of other women. In this way, she acted as not only a tour guide, but also as a witness who testified to the social and political background underpinning the art in the exhibit.

As an artist herself, Jaime identified with the struggles of other Indigenous artists who used their work to generate a conversation within Canada about Indigenous communities. In her tours, Jaime encouraged pride in cultural identity by “...talking about the beauty of Métis culture through Christi Belcourt's piece." ${ }^{8}$ Métis painter Christi Belcourt began her life as an artist in 1993 and has since become well known for her depiction of traditional Métis beadwork and

\footnotetext{
${ }^{5}$ The Sakahán exhibit described is an international exhibition of Indigenous art that displayed at the National Gallery of Canada from 17 May 2013 to 13 September 2013. It portrayed over 150 pieces of Indigenous art and was supplemented with a variety of community programming for youth and for the general public. See National Gallery of Canada, "Sakahán: International Indigenous Art," Date Accessed 01 February 2014: http://www.gallery.ca/sakahan/.

${ }^{6}$ Jaime Koebel, Email Communication, 12 October 2013.

${ }^{7}$ Interview with Jaime Koebel, Interview, 30 October 2013, 7-8.

${ }^{8}$ Ibid., 8.
} 
patterns. ${ }^{9}$ In 2014, Christi Belcourt received an Ontario Arts Council Indigenous Art Award. At this time she was given the opportunity to nominate the Ontario Arts Council Emerging Artist for 2014; Belcourt named Jaime Koebel. ${ }^{10}$ In her Sakahán tours for gallery visitors, Jaime also discussed the concept of communal strength and "resiliency" through the work of Rebecca Belmore. ${ }^{11}$ Anishinaabe artist Rebecca Belmore has taken a pointed socio-political stance with her artwork, demonstrating not only pride in her ancestry, but cultural resistance through a variety of visual and media art forms. She has been working since 1987 and has reached international renown, representing Canada at Venice Biennale's Canadian Pavilion in 2005 with her work "Fountain." "12 Jaime has situated herself amongst these peers in Canada as an "Indigenous Arts Activator." She defines this term on her website as an artist who disseminates "stories and teachings about social, political and cultural matters through Indigenous arts and culture." 13 More specifically, Jaime has chosen to 'activate' her audience through her Métis drawings, beadwork, drum art, fish-scale work, and dance.

Jaime's primary role in Sakahán has been the education of Indigenous youth. The Sakahán exhibit was held from 17 May 2013 to 7 September 2013 at the National Gallery of Canada. In their 'Youth Programming' video, the National Gallery of Canada outlined new

\footnotetext{
${ }^{9}$ Christi Belcourt, "Artist Statement on Floral Work," Christi Belcourt: Michif, Metis Artist / Mother Earth Lover / Ma'iinggundodem, Date Accessed 9 November 2014, http://christibelcourt.com/artist-statement/\#.

${ }^{10}$ Ontario Arts Council, "Christi Belcourt receives 2014 Ontario Arts Council Indigenous Arts Award," News, Date Accessible 18 June 2014, http://www.arts.on.ca/Page5506.aspx.

${ }^{11}$ Interview with Jaime Koebel, 8.

${ }^{12}$ See Department of Canadian Heritage, "Exhibition Chronology," Rebecca Belmore, Date Accessible 8 November 2014, http://www.rebeccabelmore.com/exhibitions.html; Department of Canadian Heritage, "Biography," Rebecca Belmore, Date Accessible 8 November 2014, http://www.rebeccabelmore.com/bio.html; and Canada Council for the Arts, "Rebecca Belmore: Visual Artist," Governor General Awards in Visual and Media Arts, Date Accessible 8 November 2014, http://ggavma.canadacouncil.ca/archive/2013/winners/rebeccabelmore.

${ }^{13}$ Jaime Koebel, “About,” Date Accessed 8 November 2014, http://jaimekoebel.com/wordpress/about/.
} 
programs designed for youth in connection with the Sakahán artwork, and Jaime was largely responsible for these initiatives. ${ }^{14}$ As Sakahán educator, Jaime brought youth ages 8 to 18 closer to the artwork and the artists in the exhibit. This was partly done through tours, summer camps, a youth ambassador program, workshops with the artists, and through her Junior Curator's Program (where Indigenous youth under 18 partnered up with a local curator to help curate part of the exhibit). ${ }^{15}$ Working with Indigenous youth in a variety of ways has been personally fulfilling to Jaime:

Being able to draw all of those experiences from my past and to bring them into the artwork as something visual was something to show Indigenous youth that yes, we have these experiences in our history, but to translate it in a way that was safe for them and that opened their eyes to all of these issues at a younger age. I found these issues out at an older age... ${ }^{16}$

Jaime's use of the expression, "safe for them" is instructive. In her interview, Jaime explained, the violent context she grew up within as a Métis youth in Canada. Through examining this narrative, we learn how coming into her identity as a Métis woman and role model has intersected with Jaime's work life.

\section{The Life Story of Jaime Koebel}

I met Jaime 30 October 2013 at the National Gallery of Canada. Not surprisingly, given her experience as a memoirist, the story she shared was well organized. She grew up In Lac la

\footnotetext{
${ }^{14}$ This "Youth Programming" video is available here: (http://www.gallery.ca/sakahan/en/50.htm).

${ }^{15}$ Tours of Indigenous communities were conducted for Ottawa and surrounding areas, including Akwesasne, Tandenega, Kitigan Zibi, Maniwaki and Ganisatage. Summer camps were given locally in partnership with the Ottawa Indigenous Coalition of the United Way. See Jaime Koebel, Interview Transcript, 7; The workshop series designed to bring Indigenous youth together with Sakahán artists was called 'Our Ways, Our Stories.' Refer to "Events," Sakahán: International Indigenous Art, National Gallery of Canada, Date Accessed 02 February 2014.

${ }^{16}$ Interview with Jaime Koebel, 8.
} 
Biche, Alberta, a small but socially troubled town of approximately 3000 people. ${ }^{17}$ It was a very culturally diverse town with a large Indigenous and visible minority population. ${ }^{18}$ Jaime was born in 1978 on a small farm called Craigend. She was the only Métis within her family. Her biological father was Métis but he was an infrequent figure in her life. Jaime's maternal family was German and expanded to include her stepfather when Jaime was five years of age. When twelve-year-old Jaime began to be bullied for her Indigeneity, however, she did not have family members who could identify with her experiences.

Jaime was the recipient of verbal and physical abuse as a Métis youth. She went to school with students from many racial backgrounds, including First Nation, Métis, and new immigrant students. In this mosaic, she nevertheless had to deal with numerous racial slurs including the term "Pauite," a slang term for a person who abused alcohol. She was also called Redskin, squaw, and jigaboo. ${ }^{19}$ Attending school was quite a physically violent experience for Jaime: “I'd walk out of the classroom, I'd be punched in the head; I'd be chased home by swarms of girls. I had stitches at a point. They would walk, at one session they walked right into my house to try to find me but my [stepdad] was there and kicked them out." These difficulties at school became an added source of family stress and tension: "I think it was really hard for my mom because she worked three jobs and my [stepdad] had, my stepdad had severely hurt his back so he wasn't able

\footnotetext{
${ }^{17}$ Ibid., 1.

18 In 2001, when Jaime had just moved away from Lac la Biche, Statistics Canada showed the city to have maintained the kind of cultural diversity Jaime discussed. Out of 2776 individuals, 920 self-identified as Indigenous in the 2001 census, while 310 identified as part of a visible minority group. See "Archived Content: Community Highlights for Lac la Biche," Statistics Canada, Last Modified 26 August 2013: http://www12.statcan.ca/english/profil01/CP01/Details/Page.cfm?Lang=E\&Geo1=CSD\&Code1=4812035\&Geo2=P $\underline{\mathrm{R} \& \operatorname{Code} 2=48 \& \mathrm{Data}=\text { Count } \& \text { SearchText }=\mathrm{lac} \% 201 \mathrm{a} \% 20 \mathrm{biche} \& \text { SearchType }=\text { Begins } \& \text { SearchPR }=01 \& \mathrm{~B} 1=\mathrm{All} \& \mathrm{Cust}}$ om $=$.

${ }^{19}$ Jaime Koebel, Email Correspondence, 12 December 2013; Interview with Jaime Koebel, 2.
} 
to work...being that age was really hard" ${ }^{20}$ It was not the physical violence that left scars on Jaime, however. The verbal abuse mentioned earlier affected her self-confidence over the years. $^{21}$

Jaime did not understand the full implications of what it meant to be Métis: "As a young Métis student growing up in an area so rich with history, I feel that I was cheated out of a past that I could have used to establish my identity, thus enhancing my self-esteem as a young woman.” In her memoir, Jaime expressed regret for having grown up without knowing "cultural heroes such as Louis Riel, Jim Brady, Malcolm Norris, Maria Campbell, Gabriel Dumont, Olive Dickason or David Thompson's wife Charlotte Small-Thompson..." ${ }^{22}$ It was only as an adult that she first learned of prominent and influential Métis in Canada. When Jaime looks back on her life, she perceives herself to have struggled with these cultural differences: "I soon realized that throughout my teen years, I was experiencing the ups and downs of growing up without a firm identity... On the one hand, I was trying to understand the intricacies of my 'Nativeness' with the life I was experiencing as a teenager in both my home town and, on the other hand, as a teenager who advocated for Indigenous issues at a national level." ${ }^{23}$ Fortunately, Jaime had a good support network of female family members who saw how important it was for Jaime to understand her cultural background.

Jaime began to learn about her Métis heritage through the efforts of her mother and her grandmother. In her interview, Jaime explained how these strong German women were the only

\footnotetext{
${ }^{20}$ Interview with Jaime Koebel, 2.

${ }^{21}$ Koebel, "My Story: Reflections on Growing Up in Lac la Biche,” 355.

${ }^{22}$ Ibid., 357.

${ }^{23}$ Ibid., 363.
} 
Caucasian women she knew who embraced Indigenous culture and values in Lac la Biche. They made these efforts because they wanted Jaime to know her cultural heritage. Indigenous communities in Lac la Biche responded accommodatingly and welcomed the three into the cultural life of the First Nation community of Beaver Lake, Kikino Metis Settlement and Buffalo Lake Metis Settlement. Jaime told me: "I grew up with ceremony...sweat lodges and feasts...fasting for days, fish frys, round dances and all of those community events that we had gone together to." 24

Ten-year-old Jaime also became involved in her local National Association of Friendship Centre (NAFC) in 1988 when her mother began to volunteer with the organization. This was her first work experience for her cultural community. Jaime took on greater responsibility at fourteen when she became the NAFC local youth representative for Lac la Biche in $1993 .{ }^{25}$ Jaime travelled to Ottawa four times per year in this role and glimpsed what the world was like beyond her hometown. ${ }^{26}$ In her interview, Jaime explained how grateful she was to her mother for encouraging her to pursue an active role in the cultural life of her community, and as a volunteer community worker for the NAFC more specifically: "that is probably [what] saved my life... being involved in those Aboriginal ceremonies at home, but also the advocacy away and abroad. I attribute that a lot to my mom and to a lot of the role models I had within the organization." 27 Jaime remembered how "[s]everal committed people on the NAFC board of directors saw the importance of including youth in the development of the organization and

\footnotetext{
${ }^{24}$ Interview with Jaime Koebel, 1.

${ }^{25}$ Koebel, "My Story: Reflections on Growing Up in Lac la Biche," 363; Jaime Koebel, Telephone Correspondence, 10 February 2014.

${ }^{26}$ Interview with Jaime Koebel, 2; Jaime Koebel, "My Story: Reflections on Growing Up in Lac la Biche,” 367-368.

${ }^{27}$ Interview with Jaime Koebel, 5.
} 
helped to hone the skills and confidence of young people."28 This included activities like conducting meetings and participating in conferences. NAFC work consequently provided Jaime with a valuable community work ethic, a set of professional skills, and sense of purpose throughout her life.

Becoming involved with the NAFC was also timely for Jaime as it was a resource of support. Her home life as a teen was difficult as her mother and stepfather split up at this time; this pressure built upon stress Jaime already experienced due to the bullying at school. Her home life and academic life were therefore comparably disruptive to her state of mind. These tensions were heightened for Jaime at the age of fifteen when several male hockey players she knew sexually assaulted her. During this period of her life, Jaime suffered from rumours and even ran away from home. ${ }^{29}$ Still, Jaime claimed, "[the organization] really kind of kept me going.",30 The friendship centre became a safe space and a neutral environment for Jaime to retreat from home and school.

Jaime's communal involvement in Métis culture and her community work within the NAFC therefore became a steady foundation for her identity. As the local youth representative, Jaime attended NAFC General Meetings and met numerous other youth volunteers. ${ }^{31}$ The NAFC educated Jaime and other youth representatives regarding "Aboriginal issues-everything from youth homelessness, to reserve systems, to residential schools." 32 Jaime acknowledged, her "role

\footnotetext{
${ }^{28}$ Jaime Koebel, “My Story: Reflections on Growing Up in Lac la Biche,” 368.

${ }^{29}$ Interview with Jaime Koebel, 2; Jaime Koebel, Email Correspondence, 07 December 2013.

${ }^{30}$ Interview with Jaime Koebel, 2.

${ }^{31}$ Koebel, "My Story: Reflections on Growing Up in Lac la Biche,” 363.

${ }^{32}$ Interview with Jaime Koebel, 2.
} 
as an Aboriginal person was finally starting to make sense." 33 The NAFC educated and supported Indigenous youth volunteers, providing them with perspective regarding the issues they faced in Canada as not being their fault. Jaime learnt about colonialism and its effects on addiction, homelessness, poverty, violence, and so many other things through her position as representative for the National Association of Friendship Centres. Her oral interview demonstrated how she gained more stability through being able to name all of these concepts and issues, so often experienced firsthand. Jaime wallowed in these same issues when their source was little understood by her. Jaime was therefore empowered as an NAFC volunteer. She could better recognize the systemic issues affecting her life. Instead of concentrating on her own difficulties at home and school, she could focus on serving others in her cultural community. Interestingly, Jaime learned more about her cultural identity through her volunteer work than through her home, school or community environment.

After high school, Jaime was encouraged to apply for the Transition Year Program (TYP) at the University of Alberta, a program that was designed to assist Indigenous youth integrate into western academic life. ${ }^{34}$ Jaime claims social programming like TYP was a gateway to better educational opportunities for a struggling Indigenous youth like herself. ${ }^{35}$ Through education, Jaime had drastically improved her economic opportunities. In Ben Bruman's study of urban

\footnotetext{
${ }^{33}$ Koebel, "My Story: Reflections on Growing Up in Lac la Biche," 363.

${ }^{34}$ Jaime enrolled in the Transition Year Program (TYP) at the University of Alberta. This was a one-year program designed to help Indigenous students adjust to their university community. Classes are small and filled with other Indigenous students. Students have specially designed courses that integrate Indigenous materials and subject matter into the syllabus to promote student engagement. These TYP classes are supplemented with Tutorial Sessions. Furthermore, students in this program must complete two life skill classes called Univ. 101 and Univ. 102 where students are versed in the skills of time and stress management, budgeting, as well as learning what the University of Alberta campus has to offer and how to navigate through the campus community. Students may also take advantage of the many socio-cultural activities offered through their Indigenous Student Services Centre. See University Student Services: Indigenous Student Services Centre, “TYP Program Details,” Date Accessed 01 February 2014: http://www.aboriginalservices.ualberta.ca/.

${ }^{35}$ Interview with Jaime Koebel, 3.
} 
Indigenous communities and 2006 Canadian census data, he found a large gap in unemployment statistics existed between Indigenous and non-Indigenous Canadians. Furthermore, he found this gap could be reduced through education. More specifically, $14.5 \%$ of Indigenous Canadians were shown to be unemployed in the 2006 census in comparison with $6.3 \%$ of non-Indigenous Canadians, when individuals from the groups accounted for were both actively looking for work. ${ }^{36}$ This gap reduced with increasing education levels for Indigenous Canadians, with the achievement of a high school diploma making the greatest difference for Indigenous employment. ${ }^{37}$ The unemployment rate also reduced significantly for Indigenous Canadians holding a Bachelor degree or higher level of education to a rate of only $5 \%$ unemployed. ${ }^{38}$ Achieving a high school diploma and continuing on to receive a Bachelor Degree consequently opened up new economic opportunities for Jaime. The existence of a culturally-oriented program at the University of Alberta can therefore be seen as an important effort addressing these educational gaps and associated economic opportunities in Canada.

Being accepted into post-secondary institution was really important to Jaime. In her interview, she stated how she viewed university to be her "key to get out of the town." She was aware that being accepted into post-secondary education would likely be a challenging experience, as she "had never met anyone who had been to university before." The initial rejection she experienced was difficult for Jaime: “I didn't get in the first time so I was devastated." Jaime reacted to this setback by moving to Edmonton to live with her aunt. She

\footnotetext{
${ }^{36}$ Ben Brunnen, "Indigenous and non-Indigenous Labour-Market, Education, and Occupational Distinctions in Friendship Centre and Gap Communities Across Canada," Urban Indigenous Communities in Canada: Complexities, Challenges, Opportunities, Edited by Peter Dinsdale et al (Toronto: Thompson Educational Publishing, 2011), 223 (Figure 9.1).

${ }^{37}$ Ibid., 233.

${ }^{38}$ Ibid., 234 (Figure 9.10).
} 
hoped this would provide her with a change from Lac la Biche: "I was in a situation where I sort of felt like I needed to leave my town. It was just getting out of control again." ${ }^{39}$ Unfortunately, Jaime did not have a good relationship with her aunt. This became evident in the interview as Jaime described returning home from work one evening to find her aunt had packed all of Jaime's belongings into a plastic bag and subsequently locked these items outside of the house. Nineteen-year-old Jaime then ended up staying in an Edmonton homeless shelter. Here she had the unfortunate luck of having all of her belongings stolen soon after. Jaime recalled, "That was a huge shock for me. ${ }^{, 40}$ Nevertheless, Jaime preferred to try working as a waitress, and staying in a homeless shelter, rather than return home: "I had enough clothes for work. But then I was starting to... because I was a hostess at a sports bar, I kept missing the eleven o'clock curfew. So I would have to find places to stay and they weren't always very good places (clears throat)...I think I stayed there for a while and tried to manage it and it was just not working out. I went back to Lac la Biche...." At this crucial moment in her life, Jaime "finally got accepted into university-on [her] second chance, [her] last kind of chance." ${ }^{41}$

Jaime attended classes at the University of Alberta in 1999, but only made it through her first year. ${ }^{42}$ She tried to balance her studies with NAFC volunteering at this time. Jaime confessed: "[t]hat year was very hard, very difficult learning about issues through things like literature. I was also coming back and forth to Ottawa still with the youth council so that was

\footnotetext{
${ }^{39}$ Interview with Jaime Koebel, 3.

${ }^{40}$ Ibid., 5.

${ }^{41}$ Ibid., 3-4.

42 Jaime Koebel, Email Correspondence, 7 December 2013.
} 
also putting a toll on my academic year ...I was on academic probation..." ${ }^{43}$ In 2000, Jaime applied for a summer job at the Aboriginal Peoples Television Network (APTN) in Ottawa and was successful. Moving to Ottawa led her to consider transferring from the University of Alberta to Carleton University. Jaime made this decision because the University of Alberta was too near to Lac la Biche and all the problems she had experienced: "I think I wouldn't have been able to go back [to the University of Alberta]. It was too close to everything that I was...” By being in Ottawa, Jaime felt she "really could make a fresh start...focus and not have worry about who might know somebody who was from [her] home town and who their cousin might be. Because you know, their cousin might have been the one that was bullying [her] or something like that." ${ }^{44}$ Consequently, Jaime felt increased confidence as she put physical distance between herself, Lac la Biche, and her past.

Jaime moved to Ottawa permanently in 2000 but continued to struggle balancing her academics with her community work. She remembers, "[i]t was a challenging year...but I think the challenges here [in Ottawa] were better than what I would have faced if I would have gone [back to Alberta]." Jaime recalled the unsettled feelings caused by being away from everyone she knew; she also struggled personally due to a difficult relationship with a romantic partner in Ottawa at this time. Nevertheless, Jaime travelled happily as the NAFC representative to the World Conference against Racism with the United Nations in 2001. She also attended the World Summit on Sustainable Development in 2002. ${ }^{45}$ Consequently she became an even more active volunteer than she had been before and was promoted to NAFC President and Executive Youth.

\footnotetext{
${ }^{43}$ Interview with Jaime Koebel, 3.

${ }^{44}$ Ibid., 4.

${ }^{45}$ Ibid., 3-4.
} 
In this role she began to represent her cultural community on an international stage. Jaime was nominated as Youth Role Model by the National Métis Council in 2004 and National Indigenous Role Model by the Indigenous Health Organization in the same year. ${ }^{46}$ As a means of coping with her personal life, Jaime continued to rely on NAFC work where she was recognized positively as a Canadian role model.

Jaime also spent time at the Aboriginal Centre at Carleton. In her interview, Jaime recollected how at home they made her feel: "My first year at Carleton I saw a woman by the name of Madeleine Dion Stout...she spoke to me in Cree and I just about melted. It was so nice to [see] at least one familiar face. ${ }^{, 47}$ This was important to Jaime as she felt herself to be in a state of "culture shock" when she moved to Ottawa. Jaime contended, "I was so used to Aboriginal people being brown, like me. You know I was not used to people not understanding or accepting ...Métis people.” Lac la Biche was surrounded by two Métis settlements and a First Nation settlement. In Ottawa, however, Jaime found herself having to defend her Métis identity against other First Nation students. As a newcomer, she recollected that “...many First Nations [had] a different experience of who Métis [were] here in Ottawa." To other students she met the Métis were “"wanna-be’ First Nations.” Furthermore, she “...even had First Nation students say being Métis doesn’t make sense. You're either First Nations or you're not...or that being Métis was a fake culture that was really borrowing from two other cultures. ${ }^{״ 48}$ In Ottawa, therefore, Jaime had to more assertively communicate who she believed herself to be and the inherent value of this identity.

\footnotetext{
${ }^{46}$ Jaime Koebel, “Awards / Recognition,” http://jaimekoebel.com/wordpress/awardsrecognition/, Date Accessed 8 November 2014.

${ }^{47}$ Interview with Jaime Koebel, 4.

${ }^{48}$ Ibid., 4.
} 
To Jaime, identifying as Métis was necessary because of her geographic, genealogical, and cultural ties to other Métis and Cree groups in Lac la Biche. Jaime described this personal affiliation elegantly:

We come from the same land as other Métis. We're related to other Métis. And I did my genealogy - it's like Métis, Métis, Métis for at least seven generations until you get to my dad's dad who was French...Before that it's Métis and there is one First Nation over here. I really do feel now - after going through that - Métis. I have strong connection to Cree culture because that's where Métis roots come from. It's the Cree culture. So even growing up with the language and taking it in school as well. That was really how I came eventually to identify as being Métis. ${ }^{49}$

In her interview, Jaime clearly integrated an understanding of Métis roots into her sense of self. These definitions have closely paralleled the work of North American scholars studying Métis communities in Canada, who argue that "geography, mobility, and family" have historically been defining characteristics of Métis culture. ${ }^{50}$ Jaime similarly perceived her identity to be demarcated on these same lines. She was able to gain this understanding through participating in the cultural life of Lac la Biche, working on a voluntary basis for the NAFC over the years, and by learning over time how to communicate her Métis concept of self to others.

Identity has been a contested site of meaning for Indigenous peoples, but especially so for individuals identifying with the Métis Nation in Canada. This has been due to the very present issue of defining what it means to be Métis, a conversation in which the Métis Nation has a very real social, political and economic stake. ${ }^{51}$ However, what it means to be Métis has been

\footnotetext{
${ }^{49}$ Ibid., 5.

${ }^{50}$ See Nicole St-Onge, Carolyn Podruchny, and Brenda Macdougall, eds., Contours of a People: Métis Family, Mobility and History. Edited by (Norman: University of Oklahoma Press, 2012), 5-13.

${ }^{51}$ These definitions become significant as negotiations between Indigenous communities and the federal government of Canada has been pursued along various lines of argument: those with historical treaties showing title to land have argued for rights based on their presence since the period of contact, whereas those without treaties, or new peoples
} 
variously defined, and is still in the process of being understood by scholars, the Métis community in Canada, and the Canadian government. ${ }^{52}$ Little wonder that individuals like Jaime Koebel have struggled to at first identify they are Métis, and then to assert this newfound identity on their journey to identity cohesion and socio-political recognition. Jaime has suggested that the last decade has offered increased awareness about Métis culture in Ottawa: "Now they're a little more understanding that Métis people have an actual culture, that there's a history, that there's a language and it's the youngest culture in the world. That's taken a bit of time but...that is how it is in any community that you go into for the first time." ${ }^{53}$ Being interrogated by fellow Indigenous students at Carleton may have been unsettling for Jaime as a young woman, but this was nevertheless helpful in fostering a desire to more greatly understand and articulate her own Métis identity.

Jaime's personal life changed tremendously at the end of her second year at Carleton.

Jaime became the mother of twin girls on 01 February 2002, and this was followed by the birth of her son eighteen months later when Jaime completed the last year of her undergraduate degree. ${ }^{54}$ Jaime revealed, "I had three kids in eighteen months...finished [school] though so that

like the Métis, have emphasized Indigenous rights as title to the land. These polarizing views have fractured the previous unification of Indigenous communities, once strong in unilaterally defying assimilationist policies like the 1969 White Paper Proposal and the attempt to exclude Indigenous rights from the 1982 Constitution Act. See J. R. Miller, Skyscrapers Hide the Heavens: A History of Indian-White Relations in Canada (Toronto: University of Toronto Press, 1989), 225-261. Politically, the Canadian government has only recognized the rights of Indigenous people in Canada in the 1982 Constitution Act where they legally defined the term Indigenous to include First Nation, Métis and Inuit communities in Canada, and subsequently recognize the existing treaty rights of these groups.

${ }^{52}$ Helpful summaries of this complex history can be found in Jacqueline Peterson and Jennifer S. H. Brown, eds., The New Peoples: Being and Becoming Métis in North America, Edited by (Winnipeg: The University of Manitoba Press, 1985), xi-7, as well as St-Onge, Podruchny, Macdougall, eds., Contours of a People: Métis Family, Mobility and History, 3-4. See, too, The Metis Nation (Ottawa: Metis National Council, Fall 1984).

${ }^{53}$ Interview with Jaime Koebel, 5.

${ }^{54}$ Ibid., 5. 
was good. I started a Master's degree." ${ }^{55}$ Jaime remembers fondly how she was able to rely on the support of her sister during this period: "Fortunately, my sister, who was eighteen at the time, sacrificed four months of her young life to come live with me in Ottawa to help me take care of the girls...She was a Godsend at the perfect time. ${ }^{56}$ Balancing her academic work as a student with her work in the home as a mother was difficult for Jaime. This became increasingly complicated as Jaime and the father of her children separated in 2005; her youngest son was approximately eighteen months. This led to a period in which Jaime "discovered, or rediscovered in a more... poignant way-issues around addictions." In her interview Jaime implied that this addiction was alcohol related as she described ongoing struggles to be "sober and clean." This was also the period in which Jaime began her work as an artist and began writing her memoir. Jaime met a new partner in about 2007 and he also had three children; they began their life together as a blended family. ${ }^{57}$ Jaime consequently experienced challenges to educational attainment that have affected many Indigenous persons in Canada; working to support her family and raising her children has continually competed with her academic responsibilities.

As a single parent, Jaime had to balance many work commitments: "I was still trying to finish my Master's degree, still raising my kids in time of my own, and doing contract work." ${ }^{58}$ Amanda Parriag and Paul Chaulk argue that Indigenous persons in Native Friendship Centre regions completed their final post-secondary education at a more mature age than non-

\footnotetext{
${ }^{55}$ Jaime received her Bachelor of Arts from Carleton in 2004 in Canadian Studies with a concentration in Indigenous art, political and cultural studies. She began a Master of Art's Degree in Canadian Studies in the same year but has not been able to complete this degree as of yet. Interview with Jaime Koebel, 5 .

${ }^{56}$ Koebel, “My Story: Reflections on Growing Up in Lac la Biche,” 374.

${ }^{57}$ Interview with Jaime Koebel, 5.

${ }^{58}$ Ibid., 5-6.
} 
Indigenous persons in Canada; these difficulties arose from "barriers to access housing, child care, transportation, and other necessities," of which the more serious challenge cited was found to be childcare ${ }^{59}$ Consequently, Jaime has held many concurrent work roles since entering university, in casual work positions, as a student, and as a mother.

Since completing her undergraduate degree, Jaime has been drawn to work experience related to Métis communities. From 2007 to 2010, she was employed first in Public Relations and then as Federal Liaison and Communications Officer for the Métis Settlements General Council. What Jaime dwells on more heavily in her interview, however, has been her 2011 position at the Métis National Council (MNC). She now considers this to have been "a huge mistake...It was a very abusive environment... anyone who has ever worked there will say the same thing."

Jaime was hired at the MNC to interview Métis residential school survivors. A combination of factors made this position trying for her: "while I was there they had cut all of these jobs. That was the federal government...I had remained through all those cuts. In fact they had just hired me while everybody was being cut. That was really strange for a lot of people. So there was some animosity in the last few days.... ${ }^{, 60}$ Consequently, part of Jaime's difficulty lay in the atmosphere inspired by an environment where government funding was reduced. Organizations like the Métis National Council received less funding despite a timely need to

\footnotetext{
${ }^{59}$ Amanda Parriag and Paul Chaulk, "Educational Profile of a People Living in Friendship Centre Catchment Areas Across Canada," Urban Indigenous Communities in Canada: Complexities, Challenges, Opportunities, " Edited by Peter Dinsdale, Jerry White and Calvin Hanselmann (Toronto: Thompson Educational Publishing Inc., 2011; Association of Community Colleges, Trends in Higher Education Vol. 1 (Ottawa, Ontario, 2007); A. Parriag, Paul Chaulk et al. A Literature Review of Factors that Support Successful Transitions by Indigenous People from k-12 to Post-Secondary Education (Ottawa: Council of Ministers of Education Canada and Statistics Canada, 2010).

${ }^{60}$ Interview with Jaime Koebel, 6.
} 
interview and document stories of remaining residential school survivors and prepare for Truth and Reconciliation litigation. This led to job loss and tension amongst coworkers.

For Jaime, however, the chief difficulty in working for the Métis National Council lay in her relationship with her immediate superior. Jaime clarifies the abuse she experienced in the workplace, “...it was mostly with the elected representative...there was name calling, [and] there was...really outrageous demands. There was just abusive dialogue...from one particular person.” Communication with a certain colleague from work therefore became a major source of work dissatisfaction for Jaime during this period. The second aspect that affected Jaime's work experiences at the Métis National Council was the result of the difficult nature of her work. She was assigned to interview residential school survivors and received little support to complete this sensitive portfolio well:

After I had done the interviews (clears throat)...it was devastating. I had asked for a counsellor and nothing was provided...not just for myself, but for the people I was interviewing. This was the first time that a lot of people had talked about...their experience in missions, day schools, boarding schools, residential schools, and it was really traumatizing. I'm not a counsellor. It was really traumatizing for them (emphasis)...to have never told anybody before, and then to tell me on camera, and then to go home that night... after they had been...these full grown men had been crying...to go spend...time with their family...They had never told their family... It was a really hard thing to do. I ended up without any sort of support. I ended up taking six months of leave from there. I just had no energy ...to fight against the things that were happening...the abuse of the situations that were happening at the workplace. ${ }^{61}$

Jaime objected not only to her own treatment as a worker at the Métis National Council - she could not withstand the lack of support for interviewees sharing difficult memories. Such an oversight was unethical to Jaime. She opted to take a six-month leave when she did not feel her advocacy for these interviewees to be valued in the workplace.

\footnotetext{
${ }^{61}$ Interview with Jaime Koebel, 6-7.
} 
Following her experiences at the Métis National Council, Jaime told me she took "a good long break and [did] some work around healing." She then learned of a job competition at the National Gallery of Canada for the position of Sakahán Educator. Jaime was hired into the National Gallery of Canada after interviewing with the Chief Educator, the Head Curator of the National Gallery, and also a staff member from Human Resources. Her position began in February 2013 and continued until early November 2013.

Jaime insisted to me that work at the National Gallery of Canada was very fulfilling. She was able to perceive how educating the public through Indigenous art could be a feasible direction economically. ${ }^{62}$ Furthermore, Jaime was very impressed by the workplace environment, feeling that her "training was ace." ${ }^{63}$ Megan Richardson, the Director of Education, made Jaime feel welcome by introducing her to all staff members at the gallery, providing her a tour of the entire building, and assisting her with the logistics of the institution, including getting a security pass and working with security. Furthermore, Jaime felt that the staff appreciated her contributions: "they were very patient and understanding and also open to hearing my ideas." ${ }^{64}$ This contrasted sharply with her earlier experiences in previous workplaces: "I had never been treated so well by a boss in my life. ${ }^{\prime 65}$ Because Jaime had known workplace abuse from a superior in a previous organization, she really appreciated the encouragement of the Director of Education at the National Gallery of Canada. Jaime could offer her creative strengths to this

\footnotetext{
${ }^{62}$ Ibid., 7.

${ }^{63}$ Ibid., 9.

${ }^{64}$ Jaime Koebel, Email Communication, 12 October 2013.

${ }^{65}$ Interview with Jaime Koebel, 10.
} 
position because she felt supported and valued in what she could contribute to the delivery of Sakahán programming.

Working at the National Gallery of Canada was very healing to Jaime. Although the staff at the gallery made mistakes along the way, Jaime remembers that they generally did their best to work and communicate respectfully with Indigenous staff members, resolving issues of crosscultural awareness. Jaime was especially concerned with the bureaucratic policies she encountered when organizing a welcoming ceremony for the exhibit:

We also wanted to recognize the Algonquin people of the territory and make sure that they had the opportunity to welcome these Indigenous artists from around the world. It was a bit interesting that I was told that I needed to ask permission to have the welcoming. To me that didn't sit well because Algonquin people don't need permission to welcome people - even if it happened to be on the property of the National Gallery (because it's technically unceded territory of the Algonquin people). So that was just because that was the hierarchy [the staff] was used to. My process is to-being on a territory that's not mine-is to respect the territory that I'm on. That was my hierarchy if you will. It's more of a mutual respect type of thing because if they were in my territory they would know to do the same thing. It was a huge learning curve for me...It was just sort of shocking that they would think we needed permission. ${ }^{66}$

Jaime was pleased when these issues were resolved. The gallery responded by welcoming her suggestions. Not only did the National Gallery of Canada invite Algonquin elders to hold a welcoming ceremony, managerial staff also attended the event. ${ }^{67}$ Jaime also instructed the gallery in other instances, such as how to appropriately remunerate elders for their time, how security should accommodate the laying of tobacco in parts of the gallery, and that staff should be able to recognize and allow ceremonies like ritual smudging. ${ }^{68}$

\footnotetext{
${ }^{66}$ Ibid., 10.

${ }^{67}$ Ibid., 10.

${ }^{68}$ Ibid., 8-9.
} 
Jaime also received gifts from those attending tours while she was Sakahán Educator. As an Indigenous woman, Jaime viewed gift giving to be an appropriate custom following an educational tour. These gifts were exceptional for a contract worker of the gallery, however; gallery management approved of this custom so that Jaime was able to accept gifts from schools, Indigenous organizations and Indigenous artists. ${ }^{69}$ Jaime concludes: “[t]hat's been my experience here, it's been a healthy experience, it's been fulfilling absolutely, and it's been just... given me hope for this idea of making change through art.." ${ }^{, 70}$ She enjoyed a very amicable relationship with her coworkers at the National Gallery. Indeed, during our interview seemingly every individual walking into the cafeteria waved or nodded to Jaime as I recorded her story.

Jaime held other minor positions in her career, but did not find any as fulfilling. She has been a contract instructor at Algonquin College and at Carleton University, but preferred teaching through art at the National Gallery of Canada. "I "I was fascinated with people [at the Gallery] who wanted to learn about Indigenous art. Those are the people I wanted to teach-those who wanted to learn. I had been in the [post-secondary] classroom where some people had to be there because it was part of the police foundations program...but they didn't want to be there."72 Teaching about Métis and wider Indigenous issues to public visitors to the Sakahán exhibit was therefore more personally rewarding to Jaime. She perceived this audience to have a more genuine interest in what she had to share in comparison with some previous teaching positions at Ottawa post-secondary institutions.

\footnotetext{
${ }^{69}$ Ibid., 10.

${ }^{70}$ Ibid., 8 .

${ }^{71}$ Jaime was a contract instructor at Algonquin in 2005 and at Carleton University in 2011-2012. Interview with Jaime Koebel, 7.

${ }^{72}$ Ibid., 7.
} 
In her interview, Jaime expressed how, although she enjoyed working for the National Gallery of Canada, she ideally preferred to work for her own cultural community without the bureaucratic structures she encountered in government and government-funded institutions. Jaime mentioned that she knew other Indigenous public servants were able to work directly with Indigenous communities. However, she perceived these workers to be less welcome in communities because of their role as government representatives. She reflected, "I'd rather not have that tension I suppose.. ${ }^{73}$ Moreover, Jaime has had many friends work for the federal government and has based her position on what she has learned from these acquaintances: “...a lot of them are there for a job. Some people think that they can actually make a change inside but I just feel like I wouldn't find it fulfilling... because it seems so far away from the kind of change that I hope to make." 74 Jaime preferred to work immediately with Indigenous people and with the public to influence the way Indigenous communities have been viewed within Canada; she also wished to complete this work in a dignified manner. ${ }^{75}$

This has not always been possible in every position Jaime has held. For example, Jaime has performed during Aboriginal Awareness Week previously and found this method of educational work less personally satisfying: “...for the last several years I would go into government buildings and not only talk about Métis culture but perform dancing for them to show what Métis culture is. I just found that over the past few years...it's starting to feel humiliating." This discomfort has specifically arisen from dancing in front of a passerby audience in a public space. Jaime has not objected to all dancing for Métis awareness: "[i]f it's a

\footnotetext{
${ }^{73}$ Ibid., 12.

${ }^{74}$ Ibid., 11 .

${ }^{75}$ Ibid., 11-12.
} 
captive audience then I would kind of prefer that but otherwise it just feels like I'm on the street corner asking for change but I'm actually getting a cheque from the government." Jaime consequently has not felt that her role as a cultural educator has been given the same degree of respect and value in some of her federal contracts as it has through other mediums of education. She does not feel comfortable performing dancing on the margins of libraries or other public spaces to a passerby audience during Aboriginal Awareness Week, a period designed to respect and engender awareness of Indigenous culture and contributions to Canada. Consequently, she has since decided to concentrate her energies on other avenues of change. ${ }^{76}$ Most recently, Jaime opened "Indigenous Walks," a new business where she educates the public on her own terms. For a modest fee, Jaime has provided an opportunity for tourists and natives of Ottawa to walk through the nation's capital, viewing the cityscape through an Indigenous lens. ${ }^{77}$ In this way, Jaime has begun a new chapter of her life as an Indigenous tour guide and educator. She nevertheless has continued to chart a similar path in working for her community to make Indigenous issues visible.

During our time together, it struck me how closely Jaime intersected her identity formation as an individual with her working life. Jaime held a variety of working roles-as a student, a mother, a community volunteer and a contract worker. It was in the last two forms of work within her narrative, however, that Jaime most heavily explored and built her sense of self. Jaime recounted how she tragically experienced many of the systemic social problems affecting Indigenous communities in Canada: bullying, homelessness, addiction, and violence against

\footnotetext{
${ }^{76}$ Ibid., 12.

77 Jaime Koebel, “About Indigenous Walks," Indigenous Walks, http://indigenouswalks.com/about/. Date Accessed 10 November 2014.
} 
women. Her volunteer work for the National Association of Friendship Centres in particular assisted her with understanding the larger context of colonialism that has contributed to this environment of marginalization. She also gained professional skills and self-purpose through her volunteer work for others.

In regard to paid work, Jaime filled Indigenous positions in various organizations where she maintained a focus work with or for her Indigenous community. She has worked for the federal government as a Métis dancer during Aboriginal Awareness Week. Instead of increasing Métis awareness, however, she perceived dancing for a busy passerby audience to increase her feeling of marginalization. Jaime has also worked for the Métis National Council where she interviewed Métis residential school survivors. Unfortunately, she owns to having been harassed by her superior in this organization. She also felt that she had little input into the method in which she worked with Indigenous communities to conduct these interviews. Jaime resigned from work in these particular environments, channeling her energy into her next placement as Sakahán Educator at the National Gallery of Canada. Jaime truly benefited from the atmosphere at the Gallery where she was encouraged to contribute her suggestions for cultural sensitivity and programming delivery. She was consequently able to fulfill her work description as educator to Indigenous youth and the larger Canadian public through the art of Sakahán. Moreover, Jaime has continued her educational work as the owner and tour guide for Indigenous Walks. Here, she provides an opportunity for tourists to view Ottawa through an Indigenous perspective. Through these various unpaid and paid work positions, Jaime has developed an identity as an Indigenous representative and educator. Many of the traumatic experiences she was exposed to in her youth have created a desire in Jaime to help other Indigenous youth and to generate awareness about social and cultural issues experienced within Indigenous communities in Canada. It has been 
through work that Jaime has formed a sense of self and expressed her newfound self-purpose to others.

I really enjoyed my time with Jaime, although I found certain moments of her interview to be upsetting and emotional for both of us. Her life story was framed as a journey towards selfunderstanding and healing, and a persistent sense of being on the margins whether in a "native" or "settler" space. Her narrative was inspiring to hear as a listener. Jaime has been able to utilize the social supports made available to her through her cultural community at home and the National Association of Friendship Centres across Canada. She has successfully navigated the challenges of acquiring a university degree and of moving through the Canadian labour force.

\section{Multiple Presentations of the Self}

As a researcher, a listener, and a fellow woman, I came to both know and admire Jaime. These feelings were first a reaction to meeting Jaime at the interview, but have since been expanded through the many hours since as I listened, transcribed, and corresponded with Jaime for this project. But I have also come to know Jaime through her personal memoir, "My Story: Reflections on Growing Up in Lac la Biche.” This was something Jaime directed me to read if I wanted more information about her difficult formative period in Lac la Biche. ${ }^{78}$ Jaime mentioned in our interview, somewhat cryptically, that the memoir published was not the version she originally approved; however, she decided to simply accept this fact and further the discussion her memoir would engender. In addition to writing her memoir, Jaime told me she began to share testimonies of her experience as a rape victim. ${ }^{79}$ Reading the memoir was puzzling to me as I

\footnotetext{
${ }^{78}$ Interview with Jaime Koebel, 2.

${ }^{79}$ Ibid., 2.
} 
found the presentation of Jaime's life to be markedly different from what she shared with me in her 2013 interview. Such a discovery caused me to doubt the purpose of recording life stories if one narrative could put into question the message delivered by the other. Why were these two life stories different? What could explain such a marked contrast? What were we to make of all this apparent narrative inconsistency?

In her 2013 interview, Jaime introduced life obstacles into her narrative as events that were challenging but nevertheless necessary for her preparation for her life in the present: as a community volunteer, a university graduate, an artist, an experienced cultural educator, and a mother. Jaime did not over-emphasize or dwell on many of the difficult episodes of her life in her interview. When Jaime mentioned the various hurdles along the way, she did so by outlining their role in making her a resilient person: "I've been able to deal with a lot of them. They mean something to where I'm at now...I can draw some strength from [them] as opposed to wallowing in [them]. ${ }^{, 80}$ In this way, Jaime's life interview placed emphasis on the obstacles in her path, the various supports she utilized to overcome these areas, and the way in which these experiences helped to establish the person she became.

Jaime's 2007 memoir painted the same challenges in a far more graphic and personal rendition of life experiences that included child abuse, bullying in junior high and secondary school, and being raped as a young woman. Jaime's discussion of her home, if mentioned at all, located the physical space of home as a place of relative safety in her life interview. There was no discussion of Jaime's suffering of child abuse in this home environment. Her stepfather was only mentioned in the interview as protecting her from teenage bullies who barged into her home

\footnotetext{
${ }^{80}$ Ibid., 5-6.
} 
to hurt her. ${ }^{81} \mathrm{He}$ was therefore a protector that shielded her from outside violence in at least this one instance. Her mother was described as a woman, who may have had anger problems, but who certainly saved Jaime's life by connecting her with the National Association of Friendship Centres. ${ }^{82}$ It was the outside world that Jaime largely depicted as destructive to her body and self-esteem.

In her 2007 memoir, however, Jaime claimed that her stepfather beat her with a leather strap and also hit her across the face. She admits she avoided school one day because she wanted to hide the visible marks of such abuse from others. ${ }^{83}$ As a tenth grader, Jaime wrote her ability to focus in school was disrupted by dreams that brought up memories of childhood sexual abuse, but did not describe this in more detail, passing on quickly to other topics afterward. ${ }^{84}$ In her interview, Jaime told me she began to be hurt and bullied at twelve years old. In her memoir, however, Jaime seems to have experienced unhealthy violence years earlier.

One of the most evident contrasts between the two narratives has been the silence about Jaime's male relatives. Jaime's life interview frequently referenced female family members as figuring prominently in her life, with no mention of her step-grandfather. In the memoir, however, Jaime described her feeling of being ostracized by this family member: "I knew my grandfather disliked Indians, and as a half-breed kid I was enough of one to be hated by him." Jaime found this household to be verbally violent in general because her "... step-grandfather, Henry Zorn, was an angry man who was always...complaining about life in general. [His]

\footnotetext{
${ }^{81}$ Ibid., 2.

${ }^{82}$ Ibid., 5-6.

${ }^{83}$ Koebel, "My Story: Reflections on Growing Up in Lac la Biche,” 355.

${ }^{84}$ Ibid., 366.
} 
favourite thing to say to [her] grandmother was Dummkopf -in English 'stupid woman." In this way, Jaime's step-grandfather uttered racist comments in addition to his more general sexist remarks regarding all women. Jaime's memoir also recounted how she "bore the brunt of his anger" during her summer vacation; furthermore, this "included everything from name calling to other forms of humiliation to the dreaded tenseness of his silence." ${ }^{85}$ These negative associations were the only memories she attributed to her grandfather; they were overlooked or perhaps no longer seen as necessary to Jaime when she narrated her 2013 life interview.

Jaime also rarely mentioned her biological father in the interview: "I met my dadprobably when I was about five years old; It was pretty brief." ${ }^{\prime 86}$ This contrasts strongly with her memoir where he appears as a much larger figure. Jaime recalls how she was often asked who her "real dad" was when growing up; she unhesitatingly answered such prompts with the name "Randy Mercier." ${ }^{87}$ She explained in the memoir that she did so "probably secretly hoping that he would indeed become what a real dad should be." ${ }^{\prime 88}$ In reality, she interacted with her biological father "on only a handful of occasions." ${ }^{, 99}$ When she was seventeen, Jaime visited Mercier in the hospital -he was a victim of a bar stabbing. He did not recognize her when she arrived, mistaking her as his niece instead. This was very embarrassing for Jaime, because she had spent several years calling her biological father "her real dad." Jaime concluded that she would never do so again. A short while later, Jaime bumped into Mercier while she volunteered at the local friendship centre. He then introduced Jaime to "his woman;" his female companion

\footnotetext{
${ }^{85}$ Ibid., 353.

${ }^{86}$ Interview with Jaime Koebel, 1.

${ }^{87}$ Koebel, "My Story: Reflections on Growing Up in Lac la Biche,” 353.

${ }^{88}$ Ibid., 353.

${ }^{89}$ Ibid., 353. Unless otherwise stated, the details in this chapter come from page 353-355 of Jaime's memoir.
} 
appeared to Jaime as someone who had been recently battered, hiding her black eyes with sunglasses. At this time, Mercier apologized to Jaime for not recognizing her in the hospital, citing painkillers as the reason. Jaime, however, described "a sick feeling in [her] stomach...deep down [she] believed that he did not recognize [her] as his daughter..." Mercier attempted to mend his mistake; he brought Jaime to his truck camper to meet his family. He then presented her with a necklace and set of earrings that he had personally crafted from caraway seeds. Not long afterward, her biological father went to jail for domestic abuse. Jaime understandably may have longed for a protecting family member to help her through life, but this particular male relation would not be the individual to do this. His priority was to navigate his own life. In our interview, Jaime said little about Mercier, minimizing the effect he (or his absence) held in her life.

Before I read Jaime's memoir, I had almost entirely thought of Jaime's story as one of female endurance and selflessness. She had devoted her life to her volunteer work where she served her cultural community. I did not, however, know the full story regarding how far Jaime had traveled from being a struggling Indigenous youth requiring support to being the Indigenous role model I interviewed in 2013. The legacies of racism and colonialism were perpetuated by a younger Jaime. When she attended the University of Alberta, Jaime belittled First Nation peoples: "I...made comments about First Nations getting their money from their band when they were old enough, only to booze it up, buy vehicles and other merchandise, then find their cars in the pound a few days later, after their binging came to an end, instead of investing their money in education." ${ }^{90}$ These were not the words of an activist making change but of a young woman so weighed down in social malaise that she disseminated harmful stereotypes that were not true

${ }^{90}$ Ibid., 369. 
even in her own life as a university student. Jaime became aware of this misdirection when she penned her memoir, stating that she had a lot of learning to do to before she came to a place where she no longer held Indigenous communities solely responsible for actions like these. ${ }^{91}$ It has also been significant to note that Jaime was not alone in malicious actions and words towards herself and her community members. The majority of bullying, gossip and abuse she suffered growing up were caused by other Métis and First Nation youth; these children were certainly undergoing issues of their own in Lac la Biche. ${ }^{92}$ Theirs was a community of suffering. In his 2000 study of the Indigenous post-secondary school, Nicola Valley Institute of Technology in Merritt, British Columbia, Kenneth Wayne Tourand acknowledged how “internal racism” was perpetuated by Indigenous students amongst each other based on their various racial and cultural heritage. ${ }^{93}$ Consequently, Jaime was far from unique in being swallowed within the cycle of victim of and contributor to racism.

The chief contrast between Jaime's interview and memoir rested on her testimony as a rape victim. This part of Jaime's life was hinted at in her 2013 life interview with a short reference: "Basically, when I was fifteen, the experience was having been raped by five of my friends who were hockey players. I say friends in kind of a loose term. Obviously they are not friends now." 94 Jaime's memoir, in contrast, described the incident in detail. She portrayed very graphically how, being fifteen and lured from her first junior high dance by a crush, she had alcohol funneled down her throat by boys, had drugs shot up her arm by girls, and was used one-

\footnotetext{
${ }^{91}$ Ibid., 369.

${ }^{92}$ Ibid., 364-365.

${ }^{93}$ Kenneth W. Tourand, "Honouring a Cultural Community: Embracing Indigenous Values and Traditions in a Unionized Environment” (Master's Thesis, Simon Fraser University, 2000), 48.

${ }^{94}$ Interview with Jaime Koebel, 2.
} 
by-one by five teenage males, the last for whom she had feelings. This experience only ended when Jaime murmured the words "help me," and the last boy jumped off of her, stricken by this statement. ${ }^{95}$ Over and above this experience, Jaime awoke to see the glory hole on the wall where her abuse was watched for entertainment purposes by other partygoers, knowing that everyone knew what had happened to her. ${ }^{96}$ Those aware of her rape did not intervene. The pain of the assault followed her home as her mother did not question whether or not Jaime had been hurt or assaulted, only asking if her daughter was pregnant before allowing Jaime to resume living at home. ${ }^{97}$

The sexual assault was devastating for Jaime's self-esteem. The morning after the party, Jaime witnessed the former night's violence: “As I walked into the bathroom, I was horrified to discover an uneven and crooked necklace of hickies around my throat and neck as a reminder of my night of many firsts." ${ }^{98}$ She added, "I saw the emptiness of my soul staring back at me through my own eyes. I was broken, disheveled, tainted, and yes, I had decided I was responsible for all these events...I was the bad person that I had been labelled when growing up...." ${ }^{99}$ Like many sexual assault victims, Jaime blamed herself for the criminal actions of others. Later that morning, Jaime connected with another young woman who sported a similar necklace and bruised visage. They recognized one another as victims of alcohol, drugs and sexual assault, and quietly discussed how they felt about the previous evening. When a young man entered the house asking what happened to them, the two girls mirrored one another in covering up their

\footnotetext{
${ }^{95}$ Koebel, "My Story: Reflections on Growing Up in Lac la Biche," 364-365.

${ }^{96}$ Ibid., 364-365.

${ }^{97}$ Ibid., 367.

${ }^{98}$ Ibid., 365.

${ }^{99}$ Ibid., 365.
} 
embarrassment with falsehood. Jaime reveals, "[i]n a sad and twisted moment we both looked at each other and joked about having a contest about who could sleep with the most guys that night. We both sort of just laughed at the sick joke we created...."100 Jaime could not share her real feelings about the experience for many years; they became layered in self-disapproval and blame. It was only in 2007 as the more revealing version of her memoir was published without permission that Jaime accepted her past and decided to help others through publically sharing her story of rape. Jaime claimed she felt a duty to do so; she believed that she would have benefited from having an Indigenous female role model to look up to when growing up. ${ }^{101}$

Jaime had no such example to follow, however, and found that any balance she held in her life became greatly reduced after the sexual assault. In her 2013 interview, Jaime mentioned briefly that her response to being raped was to run away. ${ }^{102}$ Her memoir, however, provided a more elaborate depiction of how the assault shocked her life and affected her future. Jaime hitchhiked to Edmonton after the assault. ${ }^{103}$ She did not tell anyone what had happened to her. She did not counter the gossip in her hometown with the truth. Jaime even denied her rape to the police. ${ }^{104}$ Our interview similarly did not discuss the results of the rape: the continual partying, addiction, the attempted suicides by pills, how she dropped out of J. A. Williams High School, and how she gave up her part-time job as a waitress in Lac la Biche. ${ }^{105}$ Jaime furthermore shared

\footnotetext{
${ }^{100}$ Ibid., 366.

${ }^{101}$ Ibid., 364.

${ }^{102}$ Interview with Jaime Koebel, 2.

${ }^{103}$ Koebel, "My Story: Reflections on Growing Up in Lac La Biche," 366.

${ }^{104}$ Ibid., 367.

${ }^{105}$ Ibid., 366-367.
} 
in her interview how difficult that year really was: "Miraculously, I somehow finished the tenth grade-alive." ${ }^{106}$

I was therefore greatly dismayed to have conducted an oral interview for the study and to have only found later that such silences occurred during our meeting. I expected gaps in memory, but the absences detailed above were no minor events within a young woman's life; these were the powerful kind of events that could have prevented her from being in a position to be interviewed that day. Perhaps she did not feel comfortable imparting all of these details to me? On the other hand, Jaime did point me in the direction of finding this information and possibly she felt that she had done enough. I began to read the work of other scholars to search for an explanation.

In his work on orality and life history, Alessandro Portelli highlighted how oral history has never provided a final story or a complete analysis of the life of an individual. Life stories change over time because "memory is not a passive depository of facts, but an active process of creation of meanings." 107 The individual, therefore, has a heavy role to play in orchestrating their memory along a narrative trajectory. Life stories have become valuable because of these "very changes wrought by memory. Such changes reveal the narrators' effort to make sense of the past and to give a form to their lives, and set the interview and the narrative in their historical context." ${ }^{108}$ Consequently, the great differences in emphasis between Jaime's two narratives can be attributed to her active process of narrative framing. Jaime's memory of these events has been dependent on the context and narration and her perception of how the past has shaped her present

\footnotetext{
${ }^{106}$ Interview with Jaime Koebel, 2.

${ }^{107}$ Alessandro Portelli, "The Death of Luigi Trastulli, and Other Stories: form and meaning in oral history (Albany, New York: State University of New York Press, 1991), 52.

${ }^{108}$ Ibid., 52.
} 
when sharing her story. Jaime's memoir was written in 2007. This was a period where she still had three young children, was a single mother, struggled with addiction, and was trying to work to support her family, while also studying for a Master's degree. This was by no means an easy point of her life. Jaime's circumstances differed greatly by 2013 when she agreed to be interviewed for this study. Jaime was no longer a new mother; she had overcome her addiction, and was just finishing up the most satisfying job she had ever held at the National Gallery of Canada. She had a new vision for her future that would provide her with an opportunity to serve her community with her strengths as an artist, and also support her family at the same time. Her 2007 memoir presented a serious and sorrowful depiction of the struggles she had faced, possibly because she was still dealing with them. In 2013, Jaime may not have felt the need to dwell on many of these details at all. When mentioned, these challenges were stepping stones along the way to a sense of personal fulfillment. In this way, the context in which the story was told has greatly affected the meaning attributed to events within the life of an individual. The social reality Jaime currently lived within changed drastically over time and her life story appears to have been similarly restructured to better mirror her state of mind.

Jaime's memory may have also affected the narrative framing of her story and how she associated meaning with the events of her life. Portelli has argued that there "is a limit to how much material can be stored in an individual's or a group's memory. Every time new information is added, old information seems to be discarded in an uninterrupted process of selection." ${ }^{109}$ This has held obvious ramifications for Jaime. Because she narrated her stories seven years apart from one another, Jaime's first story lingered more fully on details within her life before 2007, while her second narrative more carefully outlined her experiences leading up until 2013. Jaime's

${ }^{109}$ Ibid, 62. 
memoir ended with the birth of her third child, emphasizing various aspects of her early life as an abused child, a bullied teenager, a mother, a Carleton student, an NAFC volunteer, and a woman developing her Métis identity. The focal point of this story became her memories of sexual assault and how she navigated the aftermath of this event. Jaime's life interview schematically pointed to details of this early period, but more heavily filled in the information regarding her later experiences. Consequently, she discussed her various relationships and how this impacted her home life and parenting obligations. She also shared information about her participation as an Indigenous woman in the Canadian workforce, heavily detailing discrimination or satisfaction at work as the centerpiece of her narrative. The earlier sexual assault was only briefly mentioned in Jaime's 2013 interview. My initial reaction to these discrepancies has been to view such changes as the consequence of time dulling the pain of these memories, and therefore, as reducing their importance within a more current life narrative. Jaime certainly owned to undergoing a lot of healing personally and professionally in the later period of her life. Her earlier dark story may therefore have been her perception of her life during a difficult period. The markedly positive and fulfilled life story she presented in 2013 may be equally true to her as the tone of this subsequent life story reflects her newfound sense of wellbeing and recovery.

Another possibility for the distinctions in Jaime's story may lie in her active choice to tailor her life story to the Remembering the Civil Service project. I specifically asked interviewees to think about how they might prefer to share their story, as the interview would be unstructured and interviewee led, meaning I would save my questions to the conclusion of the interview and allow narrators to share their stories in whatever way they viewed as best. Jaime had no trouble with this lack of structure and came prepared with an organized narrative, showing advanced preparation. Anthropologist Julie Cruikshank has examined how oral stories 
of Athapaskan women were often told for social purpose. ${ }^{110}$ Jaime well understood that this study would be centred on the civil service. She therefore may also have organized her thoughts regarding how best to dictate the steps in her life that led her to her position at the National Gallery of Canada, de-emphasizing areas of her life related to other trajectories. Similarly, Jaime may have framed her story for her editors when writing her 2007 memoir, focusing on questions of identity and family life while growing up in Lac la Biche as a racialized young woman. After all, she was contributing to an anthology in which Métis identity and histories were being examined. Her narrative therefore hinged on her personal history and struggles with Métis identity in Canada. In this way, Jaime may have crafted her story to fit within the purpose of each project.

Through an examination of Jaime's competing stories, I at first worried that perhaps I did not forge a relationship based on mutual confidence and a willingness to share in the interview. I was concerned that I had failed to tap into the key experiences Jaime understood to be foundational to her sense of self. This caused me to doubt my ability as an interviewer and the results that might be gained from further interviews in the study. I worried needlessly. By comparing the content of each interview alongside the framing of these experiences, I actually gained a much richer understanding of not only Jaime's life but also the nature of oral history. All of the interviewees in the project may very well display similar discrepancies should their life stories be provided and examined from different vantage points of their lives. Their life stories may evolve over time as their understanding of the events of their lives shift to emphasize life meaning overall. As we saw in this chapter, this is certainly the case for Jaime Koebel.

\footnotetext{
${ }^{110}$ Julie Cruikshank, Life Lived Like a Story: Life Stories of Yukon Native Elders (Vancouver: University of British Columbia Press, 1990).
} 


\section{Chapter Five}

\section{Conclusion}

I set out with two sets of questions when I began the Remembering the Civil Service Study. The first set concerned identity. To what extent did the cultural identities of Indigenous women and men intersect with their economic identities as civil servants in the Canadian federal government? Was there conflict between these two forms of identification? As the previous chapters consistently revealed, the responses of research collaborators to these questions were deeply personal and defy easy generalization.

For individuals such as Russell Moses, their work as civil servants was closely linked and also in tension with their cultural values as Indigenous community members. Russell worked in the Canadian federal civil service in the 1960s and became well known for his support of Indigenous struggles in Canada for social, political and economic equality. During this time, Moses wrote a residential school memoir critiquing the Mohawk Institute, and more indirectly the Department of Indian and Northern Affairs (DINA), for abuses suffered while studying at this institution. ${ }^{111}$ As Special Assistant to the then Minister of DINA, Moses also kept Jean Chrétien informed of issues faced by Indigenous communities in Canada. This was so much the case that he was branded the "Red Uncle Tom" in Canadian media, as I discussed in Chapter Three. Consequently, it can reasonably be argued that there were points in Moses' career where he felt the need to critique federal policies as a spokesperson for his cultural community, but that he also believed he could affect positive change in his bureaucratic capacity. Although we can only speak to the family members of the now deceased Moses, it is nevertheless quite obvious

111 Russell Moses, “Mohawk Institute - 1942-47,” 28 December 1965. This residential school memoir was provided by John Moses. 
that his concerns for the present and future of Indigenous peoples and cultures in Canada were reflected in the various positions he held within the federal government from 1965 to 1986 . This can best be seen through Moses' long career as Editor of the Indian News, as Special Assistant to the Minister of Indian Affairs, and as the Head of the Office of Native Recruitment. He also later contributed his expertise as an Aboriginal consultant to Veteran Affairs Canada, the Senate of Canada, the Six Nations Elected Band Council and the Assembly of First Nations in his retirement.

When examining institutional records and aggregate data showing increasing levels of employment of Indigenous civil servants in the federal government, and associated efforts over time to improve the cultural sensitivity and environment of this work, it can be tempting to paint a narrative where early identity conflicts and tensions lessened over time. Listening to the life stories of women and men who have lived through these changes, however, has provided a more complex narrative. In Chapter Three, for example, John and Eric challenged the very concept that their Indigeneity and their employment might be linked in the first place. John, for example, worked for the Treasury Board Secretariat of Canada and placed a firm boundary between this work and his cultural identity. His personal interests outside of work were instead considered to align very closely with his identity as an Indigenous person of Odawa background. In his opinion, his work for the civil service was meant to serve the interests of all Canadians and not to be dependent on race or culture. Eric McGregor similarly found very little correlation between his cultural identity as an Anishinaabe person and his work as a statistician at Aboriginal Affairs and Northern Development Canada. Eric did not work directly with his cultural community and did not view race as heavily affecting his work experiences. In this way, both John and Eric 
perceived little room for identity tension in their employment because they have not viewed their work to be culturally specific.

The memories of John and Eric are in marked contrast to other interviewees who worked with and/or for their cultural communities. This was certainly the case in Chapter Four where we learned Jaime Koebel went on stress leave at the Métis National Council. This occurred in 2011 when her employers refused to provide counselling to Métis residential school survivors who shared their difficult stories of abuse in residential schools for the first time. Also, Jaime was herself exposed to this trauma as an interviewer receiving these stories; she felt she would have benefitted from support as well. Jaime was fortunate, however, in working next at the National Gallery of Canada. She found the gallery to be a more receptive employer regarding concerns of cultural sensitivity when these issues were brought to their attention. Nevertheless, Jaime did encounter moments where she found it necessary to address structures and policies she felt to be problematic at the gallery. For example, she felt strongly that Algonquin peoples should be able to greet Indigenous artists of the Sakahán exhibit through an opening welcoming ceremony in 2013. Unfortunately, Jaime Koebel found the bureaucratic structures of authority at the gallery to be tedious, being told that permission would have to be granted by management to hold such an event. According to Jaime, her instinct was to respect the rights of the Algonquin people to welcome other Indigenous guests to their own territory. After this episode, Jaime then found her role at the gallery became partly one of guidance as she assisted staff in raising awareness about Indigenous practices and how they as an institution might be more accommodating. She was happy to report to me that although there were some points of tension at work, overall the gallery was a positive environment to work within because of the willingness she observed in both 
coworkers and management to be open to her suggestions for greater cross-cultural awareness and understanding.

Ronda Evans likewise found that her identity as an Indigenous person at times came into conflict with her work as a federal government employee. In Chapter Three, we learned that Ronda worked for Health Canada as the coordinator of the Aboriginal Head Start Program from 1994 to 2012. She loved this position and she believed in this programming, because it involved Indigenous communities in the creation and development of a federal program designed to help Indigenous preschoolers and their families. Ronda explained how she was hired in 1994 and instructed to build the program so that Indigenous communities could eventually take over and run such initiatives independently. She chose to remain as the coordinator of this program, and refused promotion to other positions, because she found working with and for her community so fulfilling. Ronda was especially motivated by the original intention of the federal government to involve Indigenous communities in program delivery and development so that the Aboriginal Head Start program could one day be devolved to these communities entirely. Unfortunately, the running of the Aboriginal Head Start Program became increasingly centrally controlled by 2009, which led to the disempowerment of Indigenous communities in the program delivery and design. Ronda began to feel a conflict of interest as an Indigenous woman working in the civil service within a mandate that she did not feel served the best interests of her community. Indeed this conflict was so strong that she resigned in 2012 and opted for early retirement.

For Dave Monture, working for the Canadian civil service was both rewarding and conflicting. He began employment for the Department of Indian Affairs and Northern Development in 1969 in a variety of positions, moved to become the Ontario Coordinator of the Office of Native Employment in 1974, the National Coordinator in 1976, and returned to work 
for INAC in corporate policy in the early 1980s. As Assistant Editor and then Editor of The Indian News, Dave was able to interview Indigenous political leaders in Canada and cover controversial economic and social news affecting Indigenous communities. While working for the Office of Native Employment, he was pleased to recruit Indigenous employees into the federal civil service and also to contribute to new policies that would make the civil service a more equitable and attractive employer for Indigenous workers. Dave's work in the civil service was directly related to his background as an Indigenous person, and he chose to leave the Canadian federal civil service in the early 1980s because he found the bureaucratic structure too constraining. He could not make the changes he wished to within federal employ and was gratified to have more influence over federal policies when working with government externally as the representative of the Assembly of First Nations and a variety of other Indigenous organizations.

CQ has also found his Indigenous background to be closely linked to his work in the civil service. As discussed in Chapter Three, he was hired through Indigenous recruitment initiatives, worked with Indigenous collections at the Canadian Museum of Civilization, and later became an Indigenous specialist at the Department of Canadian Heritage. He views his mission as an Indigenous civil servant to be that of Indigenous consultant in policies that will affect his cultural community. Furthermore, he considers himself to be a modest representative for his cultural community within government. Although his cultural identity and economic identity have been tied very much together, unlike Jaime, Ronda, and Dave, CQ's tensions at work did not result from a clash between these two identities, but rather from systemic problems like career mobility, job security, and remuneration. 
When taken as a whole, the life stories and memories of work shared in this study defy a linear narrative of reduced cultural tension at work over time. Instead, these stories and memories insist that we focus on the contingency of time and place, and on the sense of self that each worker produced for themselves both on and off the job. As I first collected and later listened to these stories, it became clear to me that the nature of the work and the environment of this work determined whether or not the Indigeneity of employees was relevant to identity formation and work place memories.

The second set of questions that framed this thesis wished to explore the regulatory culture of the civil service. More pointedly, I wondered how this culture evolved as the federal government expanded to include a greater diversity of workers from minority backgrounds. Were workers aware of this regulatory culture and how do they remember it today? Exploring archival records, I found that the Public Service Commission and the Treasury Board Secretariat developed a culture of merit and representativeness that constantly evolved over the twentieth century. As discussed in Chapter One, while the Public Service Commission (PSC) helped to see the merit principle formally adopted (at least in principle) in 1908, the effect of the PSC and the merit principle had little to no impact on the opportunities afforded for hiring and promotion beyond a limited pool of white, male civil servants. Frustration became clear through the Royal Commission on the Status of Women in 1967 and the 1969 federal study entitled "Sex and the Public Service.” This movement for equality was not only influential along gender lines, but it also opened some opportunities for other marginalized workers. By the 1970s, the PSC began to examine racial inequality in the civil service. The Office of Native Employment was established in 1973 to oversee this aspect of policy direction. The result was increased research into racebased workplace barriers and discrimination, strategic recruitment initiatives designed to 
increase the representation of Indigenous employees within the Canadian civil service, and policy development to make the civil service a more equitable workplace. By the 1990s, the merit principle not only called on recruitment into the civil service to be based on recruiting the most qualified candidates for work, but also ensuring that the civil service was a sensitive and barrier free workplace for these employees; this policy also mandated efforts to ensure the civil service became reflective of the demographic of Canada as a whole.

While such structural changes have had an important impact on the changing composition of the civil service's workforce, my interviewees' stories and memories reflect that simply getting a job is not enough in order to affect lasting change for Indigenous workers, both male and female. For CQ, career development, mobility, and security were paramount concerns and caused him to leave a job he loved at the Canadian Museum of Civilization. Dave Monture desired more influence in policy decisions affecting his cultural community, especially when he perceived his superiors to make key policy decisions for Indigenous communities without experience of visiting the people who would be governed by these decisions. He found himself more successful in driving positive change within government when working outside of government as a representative of Indigenous organizations. Ronda Evans was motivated and fulfilled as a community worker who delivered cultural programming within Indigenous communities when this programming was developed through the collaboration of Indigenous communities and the federal government. For Jaime, working for the federal civil service was the best job she ever held, because she perceived the National Gallery of Canada to be genuinely attempting to both deliver culturally sensitive programming and also engender an environment of cultural sensitivity as an employer. 
While I hope that this thesis provides historical and sociological insight into the experiences and memories of Indigenous civil servants, I also hope others find inspiration in the methodology adopted. By choosing to focus my research on life stories, I have been challenged ethically, methodologically, and epistemologically. As discussed in Chapter Two, oral history is largely a field where methods are continually evolving and where best practices are continually discussed and debated. In this way, months of preparation in reading the works of other oral historians can only provide a partial foundation for what occurs when embarking on a study of your own. The researcher builds a relationship with each interviewee and essentially lives with their stories over many hours of transcription, analysis, and written compilation. The researcher also creates an individual agreement with each interviewee to represent them ethically in their work. A sense of obligation is therefore created which does not exist in the same way for other forms of history writing. Much care is therefore dedicated to reducing risk to narrators by protecting anonymity, by capturing authorial meaning, and by reflecting thoughtfully when crafting arguments. This is necessary because the history written will reflect a living research sample that will be affected by the study in which they participated. Furthermore, I fully expect (and hope) that my collaborators will read the thesis. The reality of this form of research has been that it may take more time to complete a careful and ethical oral history study than the researcher may first perceive when they set the parameters of their work. The researcher cannot control this timeline fully because they work around the schedules of many people to complete this research in addition to their own. This is necessary to reap the rewards of working with the public in this way.

Moreover, braiding together these stories has been no small task. Oral history can be messy and the researcher cannot know where their work will lead until the interviews have been 
completed. They can only write about the stories they are entrusted with and this work largely begins at the completion of many hours of interviewing and then listening. Moreover, some interviews failed and I could not bring all of the individuals I spoke with into the study. Some individuals simply did not feel they could discuss their stories on the record. Negotiating early relationship building with potential interviews is the necessary and complicated terrain as an oral historian working with the public.

If the opportunity arose to complete more of this work, I am conscious that I would try to gather a larger research sample and that I would also benefit from having a second interviewer in the study that was male. This is because I perceived a marked difference in interview structure and storytelling along gender lines. The power of gender and sense of self were clearer with respect to the female narrators. The women in the study actively weaved the stories of their lives to reflect on work in the home, in the community, and in the workplace as a paid employee. For the men in the study, I was rarely able to access stories of their private lives. This may be partly due to my age as a younger researcher. It may also have been caused by my gender as a female. Julie Cruikshank has also found in her work that male Athapaskan interviewees did not view it to be acceptable to build a relationship with nor impart their personal stories to a female interviewer. ${ }^{112}$ I think male interviewers might be more successful in helping male interviewees more easily share their personal stories. At the same time, perhaps the problem is less one of the gender profile of the interviewer and more a reflection of the gendering of work memories more broadly. ${ }^{113}$ In any respect, I hope more researchers will explore the making and experiences of

\footnotetext{
112 Julie Cruikshank, Life Lived Like a Story: Life Stories of Three Yukon Native Elders (Lincoln: University of Nebraska Press, 1990), 19.

113 Mary Jane Logan McCallum, Indigenous Women, Work, and History 1940-1980 (Winnipeg: University of Manitoba Press, 2013); Heather Howard-Bobiwash, "Women's Class Strategies as Activism in Native Community Building in Toronto, 1950-1975," The American Indian Quarterly Vol. 27, No. 3-4 (Summer/Fall 2003): 566-582;
} 
the kind of middle class Indigenous masculinity that we saw glimpses of in this thesis and which I encountered in interviews. How does masculinity and manhood affect the life stories of male interviewees and how does this affect their sense of self?

Yet here at the end of this long research project, I find myself being in the unique position of concluding that there is no simple conclusion to make about the historical sociology of Indigenous civil servants. I found the most resonant lessons were not achieved through examining the few commonalities that existed among the interviews, but by analyzing the rich differences that each narrator brought through their unique perspectives and lives. In the confines of this one thesis, there has not been the space to give these rich narratives the attention each deserves. They can be found at Archives and Research Collections (ARC), at Carleton University after the study has concluded. Working closely with Indigenous employees of the Canadian federal civil service has led me to conclude that there is not much more than this Indigeneity and this common environment of work to bind these workers together. Moreover, I began the study with expectations that the result of interviews would lead to a racialized labour history. These interviews, however, defied such an expectation. Indigeneity did not define interviewees or form the basis for many of the choices they made. Their stories were personal and unique and exploded the category of race as a defining aspect of their experiences at work. Narrators were deeply affected by gender and class dynamics as well. What these workers desired has been shown to include access to child care, salary increases, job security, career

Nancy Janovicek, "Assisting Our Own: Urban Migration, Self-Governance, and Native Women's Organizing in Thunder Bay, Ontario, 1972-1979," The American Indian Quarterly, Vol. 27, No. 3-4 (2003): 548-565; Robin Jarvis Brownlie, "'Living the Same as the White People': Mohawk and Anishinabe Women's Labour in Southern Ontario, 1920-1940," Labour/Le Travail Vol. 61 (Spring 2008) : 41-68; Julie Guard, "Authenticity on the Line: Women Workers, Native 'Scabs,' and the Multi-Ethnic Politics of Identity in a Left-led Strike in Cold War Canada," Journal of Women's History, Vol. 15, No. 4 (Winter 2004): 117-140; Joan Sangster, Transforming Labour: Women and Work in Postwar Canada (Toronto: University of Toronto Press, 2010). 
mobility, a culturally sensitive workplace, the freedom to pursue work in their community outside the workplace, and the ability to provide culturally specific programming to their community in an ethical and collaborative manner. It is not enough then to craft policies with only an Indigenous demographic in mind, but to look at workers across the civil service more holistically. This recognizes that women and men working for the federal government perform many forms of work in the home, their community, and on the job that will affect their satisfaction as civil servants. To put another way, work did not solely define the Indigenous women and men of this study as workers but it did contribute in many important ways to the making of their individual selves. 


\section{Bibliography}

\section{Primary Sources}

\section{Library and Archives Canada}

RG10. Department of Aboriginal Affairs and Northern Development Canada.

RG 32. Public Service Commission.

\section{Interviews/Email Communication}

Anonymous Participant (“John”). Email Communication. 04 January 2014.

Anonymous Civil Servant (“CQ”). Email Correspondence. 20 March 2014.

Interview with Dave Monture. 29 December 2013.

Interview with Eric McGregor. 07 November 2013.

Interview with Jaime Koebel. 30 October 2013.

Interview with John Moses. 06 December 2013. (Interview will not be archived).

Interview with Ronda Evans. 31 January 2014.

Koebel, Jaime. Email Communication. 04 October 2013.

Koebel, Jaime. Email Communication. 12 October 2013.

Koebel, Jaime. Email Communication. 07 December 2013.

Koebel, Jaime. Telephone Communication. 10 February 2014.

McGregor, Eric. Email Communication. 14 January 2014.

McGregor, Eric. Email Communication. 25 January 2014.

McGregor, Eric. Email Communication. 17 June 2014.

Monture, Dave. Telephone Communication. 11 April 2014.

Monture, Dave. Telephone Communication. 05 June 2014.

Monture, Dave. Telephone Communication. 06 June 2014. 


\section{Published Primary Sources}

A Profile of the Aboriginal Population Residing in Selected Off-Reserve Areas. 1986 Census. Vol. I (Ottawa: Aboriginal and Native Issues Unit, Statistics Canada, 1990): Table 4.08.

Abella, Rosalie Silberman. Report of the Commission on Equality in Employment. Ottawa: Government of Canada, 1984.

Department of Citizenship and Immigration. Annual Report of Indian Affairs Branch. 1960.

Department of Indian Affairs and Northern Development. Annual Report. Ottawa: 1968-1969.

Department of Indian Affairs and Northern Development. Annual Report Fiscal Year 1968-1969. Item 36072.

Dosman, E.J. Indians: The Urban Dilemma. Toronto: McLelland and Stewart, 1972, 21.

Koebel, Jaime. "My Story: Reflections on Growing Up in Lac La Biche." The Long Journey of a Forgotten People: Métis Identities and Family Histories. Edited by Ute Lischke and David T. McNab. Waterloo: Wilfrid Laurier University Press, 2007.

PS 2000: Reports and Summaries of the Task Forces. Ottawa, August 14, 1990.

Public Service Commission. Annual Report. 1968.

Public Service Commission. Annual Report. 1969.

Public Service Commission. Annual Report. 1970.

Public Service Commission. Annual Report. 1971.

Public Service Commission. Annual Report. 1972.

Public Service Commission. Annual Report. 1973.

Public Service Commission. Annual Report. Vol. 1, 1980.

Public Service Commission. Annual Report. 1981.

Public Service Commission. Annual Report. 1982.

Public Service Commission. Annual Report. 1983.

Public Service Commission. Annual Report. 1983. Table 15, 72.

\section{Newspapers}

The Indian News. 1957-1969.

The Native Perspective. 1976-1978. 


\section{Published Secondary Sources}

Armitage, Susan and Sherna Berger Gluck. "Reflecting on Women's Oral History: An Exchange.” Frontiers: A Journal of Women Studies Vol. 19 No. 3 (1998): 1-11.

Association of Community Colleges. Trends in Higher Education Vol. 1 Ottawa, Ontario, 2007.

Blanchard, David S. Kahnawake: A Historical Sketch. Kahnawake: Kanien'kehaka Raotitiohkwa Cultural Centre, 1980.

Borland, Katherine. "That's Not What I Said: Interpretive Conflict in Oral Narrative Research." Women's Words: The Feminist Practice of Oral History. Edited by S. B. Gluck and D. Patai (New York: Routledge, 1991): 63-75;

Brownlie, Robin Jarvis. 'Living the Same as the White People': Mohawk and Anishinabe Women's Labour in Southern Ontario, 1920-1940.” Labour/ Le Travail Vol. 61 (Spring 2008): 41-68.

Brunnen, Ben. "Indigenous and non-Indigenous Labour-Market, Education, and Occupational Distinctions in Friendship Centre and Gap Communities Across Canada." Urban Indigenous Communities in Canada: Complexities, Challenges, Opportunities. Edited by Peter Dinsdale et al (Toronto: Thompson Educational Publishing, 2011).

Cahill, Cathleen D. “'An Indian Teacher among Indians.' Native Women as Federal Employees." Indigenous Women and Work: From Labour to Activism. Urbana: University of Illinois Press, 2012.

Carlson, Keith Thor. The Power of Place, The Problem of Time: Aboriginal Identity and Historical Consciousness in the Cauldron of Colonialism. Toronto: University of Toronto Press, 2010.

Cruikshank, Julie. Life Lived Like a Story: Life Stories of Three Yukon Elders. Lincoln: University of Nebraska Press, 1990.

Fanelli, Carlo and Priscillia Lefebvre. "The Ottawa and Gatineau Museum Workers' Strike: Precarious Employment and the Public Sector Squeeze.” Uniting Struggles: Critical Social Research in Critical Times. Toronto: Red Quill Books: 2011.

Frisch, Michael. A Shared Authority: Essays on the Craft and Meaning of Oral and Public History. Albany, New York: State University of New York Press, 1990.

Granatstein, J. L. The Ottawa Men: the Civil Service Mandarins, 1935-1957. Toronto: Oxford University Press, 1982.

Greenspan, Henry and Sidney Bolkosky. "When is an Interview and Interview? Notes from Listening to Holocaust Survivors.” Poetics Today 27:2 (Summer 2006): 431-449.

Guard, Julie. "Authenticity on the Line: Women Workers, Native 'Scabs,' and the Multi-Ethnic 157 Politics of Identity in a Left-led Strike in Cold War Canada." Journal of Women's History, Vol. 15, No. 4 (Winter 2004): 117-140. 
Hall, John R. Reworking Class. Ithaca and London: Cornell University Press, 1997.

Heron, Craig. The Canadian Labour Movement: A Short History. Toronto: James Lorimer, 1989; 2nd ed. 1996.

Heron, Craig. "The Labour Historian and Public History." Labour/Le Travail. Vol. 45 (Spring 2000), 171-97.

High, Steven. "Native Wage Labour and Independent Production during the 'Era of Irrelevance."” Labour/ Le Travail Vol.37 (Spring 1996): 243-264.

High, Steven. "Sharing Authority: An Introduction." Journal of Canadian Studies Vol. 41, No. 1 (Winter 2009): 12-34.

Hobsbawm, Eric. "Peasants and Politics." Journal of Peasant Studies 1, No. 1 (1973): 3-22.

Howard-Bobiwash, Heather. "Women's Class Strategies as Activism in Native Community Building in Toronto, 1950-1975." The American Indian Quarterly. Vol. 27, No. 3-4 (Summer/Fall 2003): 566-582.

Janovicek, Nancy. “Assisting Our Own: Urban Migration, Self-Governance, and Native Women's Organizing in Thunder Bay, Ontario, 1972-1979." The American Indian Quarterly. Vol. 27, No. 3-4 (2003): 548-565.

Juillet, Luc and Ken Rasmussen. Defending a Contested Ideal: Merit and the PSC of Canada, 1908-2008. Ottawa: University of Ottawa Press, 2008.

Kealey, Gregory S. Essays in Working Class History. Edited by Gregory S. Kealey and Peter Warrian. Toronto: McClelland and Stewart, 1976.

Leh, Almut. "Ethical Problems in Research Involving Contemporary Witnesses." Translated by Edith Burley. Oral History Forum d'histoire orale Vol. 29 (2009): 1-14.

Lutz, John Sutton. Makúk: A New History of Aboriginal White Relations. Vancouver: UBC Press, 2008.

McCallum, Mary Jane Logan. Indigenous Women, Work, and History 1940-1980. Winnipeg: University of Manitoba Press, 2013.

Miller, J. R. Skyscrapers Hide the Heavens. Toronto: University of Toronto Press, 1991.

Ortner, Sherry. "Reading America: Preliminary Notes on Class and Culture." in Recapturing Anthropology: Working in the Present. Edited by Richard Fox. Santa Fe NM: School of American Research Press, 1991.

Palmer, Bryan B. and Joan Sangster. Labouring Canada: Class, Gender and Race in Canadian Working Class History. Don Mills, Ontario: Oxford University Press, 2008. 
Palmer, Bryan D. Working Class Experience: Rethinking the History of Canadian Labour, 18001991. Toronto: McClelland and Stewart Inc., 1992.

Parriag, A., Paul Chaulk et al. A Literature Review of Factors that Support Successful Transitions by Indigenous People from K-12 to Post-Secondary Education. Ottawa: Council of Ministers of Education Canada and Statistics Canada, 2010.

Parriag, Amanda and Paul Chaulk. "Educational Profile of a People Living in Friendship Centre Catchment Areas Across Canada." Urban Indigenous Communities in Canada:

Complexities, Challenges, Opportunities.” Edited by Peter Dinsdale, Jerry White and Calvin Hanselmann. Toronto: Thompson Educational Publishing Inc., 2011.

Peterson, Jacqueline and Brown, Jennifer S. Editors. The New Peoples: Being and Becoming Métis in North America. . Winnipeg: The University of Manitoba Press, 1985.

Phillips, Ruth B. "Disappearing Acts: Traditions of Exposure, Traditions of Enclosure, and Iroquois Masks." Questions of Tradition. Ed. Mark Salber Phillips and Gordon Schochet. Toronto: University of Toronto Press, 2004: 56-87.

Portelli, Alessandro. The Death of Luigi Trastulli, and Other Stories: Form and Meaning in Oral History. Albany, New York: State University of New York Press, 1991.

Rose, Sonya. "Gender and Labour History: The Nineteenth-Century Legacy." International Review of Social History Supplement Vol. 38 Issue 2 (1993): 145-62.

Sangster, Joan. "Feminism and the Making of Canadian Working-Class History: Exploring the Past, Present, and Future.” Labour/Le Travail Vol. 46, Special Millennium Issue (Fall 2000): 127-165.

Sangster, Joan. Transforming Labour: Women and Work in Postwar Canada. Toronto: University of Toronto Press, 2010.

Scott, James C. Weapons of the Weak: Everyday Forms of Peasant Resistance. New Haven and London: Yale University Press, 1985.

Scott, Joan W. "Gender: A Useful Category of Historical Analysis.” The American Historical Review Vol. 91, No. 5 (Dec. 1986): 1053-1075.

Sheftel, Anna and Stacey Zembrzycki. "Only Human: A Reflection on the Ethical and Methodological Challenges of Working with 'Difficult' Stories.” The Oral History Review Vol. 37, No. 2 (2010): 191-241.

Sheftel, Anna and Stacey Zembrzycki. Oral History Off the Record: Toward an Anthology of Practice. New York: Palgrave MacMillan, 2013: 1-20.

Shewell, Hugh. "Dreaming in Liberal White: Canadian Indian Policy, 1913-83." Aboriginal People: A Reader, Eds. Kristin Burnett and Geoff Read. Don Mills, Ontario: Oxford University Press, 2012: 170-178.

Shewell, Hugh. 'Enough to Keep Them Alive:' Indian Welfare in Canada, 1873 -1965. Toronto: University of Toronto Press, 2004. 
Sitzia, Lorraine. “A Shared Authority: An Impossible Goal?” The Oral History Review Vol. 30, No. 1 (Winter-Spring 2003): 87-101.

St. Onge, Nicole, Podruchny, Carolyn, and Macdougall, Brenda. Editors. Contours of a People: Métis Family, Mobility and History. Norman: University of Oklahoma Press, 2012.

The Metis Nation. Ottawa: Metis National Council. 1:6 (Fall 1984).

Thompson, E. P. The Making of the English Working Class. Harmondsworth: Penguin, 1980.

Williams, Allison M. "Canadian Urban Aboriginals: A Focus on Aboriginal Women in Toronto.” The Canadian Journal of Native Studies. Vol. 17, No. 1 (1997): 75-101.

Yow, Valerie. "Ethics and Interpersonal Relationships in Oral History Research." The Oral History Review Vol. 22, No. 1 (Summer 1995): 51-66.

Zembrzycki, Stacey. "Sharing Authority with Baba." The Journal of Canadian Studies. Vol. 43, No. 1 (Winter 2009): 219-238.

\section{Unpublished Theses and Lectures}

Phillips, Ruth. Lecture at Carleton University, Ottawa. 12 November 2012.

Pugliese, Karyn. "So, where are you from? Glimpsing the History of Ottawa-Gatineau's Urban Indian Communities.” Master's Thesis, Carleton University, 2005.

Warskett, Rosemary Elizabeth. "Learning to be 'Uncivil': Class Formation and Feminisation in the Public Service Alliance of Canada, 1966-1996.” PHD Dissertation, Carleton University, 1998.

\section{Online Sources}

Aboriginal Affairs and Northern Development Canada. "Change to the Departments Name." Last Modified 31 August 2011:

https://www.aadncaandc.gc.ca/eng/1314808945787/1314809172051.

Aboriginal Affairs and Northern Development Canada. "Indigenous Consultation and Accommodation - Updated Guidelines for Federal Officials to Fulfill the Duty to Consult March 2011.” 15 September 2010: http://www.aadncaandc.gc.ca/eng/1100100014664/1100100014675.

Belcourt, Christi. "Artist Statement on Floral Work." Christi Belcourt: Michif, Metis Artist / Mother Earth Lover / Ma'iinggundodem. Date Accessed 9 November 2014: http://christibelcourt.com/artist-statement/\#.

Canada Council for the Arts. "Rebecca Belmore: Visual Artist." Governor General Awards in Visual and Media Arts. Date Accessible 8 November 2014: http://ggavma.canadacouncil.ca/archive/2013/winners/rebeccabelmore. 
Canadian Ethnocultultural Council. “About.” Date Accessible 12 May 2015: http://www.ethnocultural.ca/about.

CBC Digital Archives. "Indian Magazine Becomes Our Native Land." http://www.cbc.ca/archives/discover/programs/o/our-native-land-1/indian-magazinebecomes-our-native-land.html.

CBC News. "Budget Cuts 19000 public service jobs." Last Modified 29 March 2012: http://www.cbc.ca/news/politics/budget-cuts-19-000-public-service-jobs-1.1170727.

Department of Canadian Heritage. "Biography.” Rebecca Belmore. Date Accessible 8 November 2014: http://www.rebeccabelmore.com/bio.html

Department of Canadian Heritage. "Exhibition Chronology." Rebecca Belmore. Date Accessible 8 November 2014: http://www.rebeccabelmore.com/exhibitions.html.

Health Canada. "Indigenous Head Start on Reserve.” Last Modified 15 June 2011: http://www.hc-sc.gc.ca/fniah-spnia/famil/develop/ahsor-papa intro-eng.php.

Koebel, Jaime. “About.” Date Accessed 8 November 2014: http://jaimekoebel.com/wordpress/about/.

Koebel, Jaime. “About Indigenous Walks.” Indigenous Walks. Date Accessed 10 November 2014: http://indigenouswalks.com/about/.

Koebel, Jaime. “Awards / Recognition.” Date Accessed 8 November 2014: http://jaimekoebel.com/wordpress/awardsrecognition/.

Aboriginal Affairs and Northern Development Canada. 'Kumik - Council of Elders.' Last Modified 15 September 2010: https://www.aadncaandc.gc.ca/eng/1100100013748/1100100013749.

Library and Archives Canada. "Expo 67 Man and His World." https://www.collectionscanada.gc.ca/expo/0533020206 e.html.

National Association of Friendship Centres. "About the NAFC.” Date Accessed: 20 February 2015: http://nafc.ca/about/.

National Gallery of Canada. "Events." Sakahán: International Indigenous Art. Date Accessed 02 February 2014: http://www.gallery.ca/sakahan/en/20.htm.

National Gallery of Canada. "Sakahán: International Indigenous Art.” Date Accessed 01 February 2014: http://www.gallery.ca/sakahan.

National Gallery of Canada. "Youth Programming." Date Accessed 01 October 2013: (http://www.gallery.ca/sakahan/en/50.htm).

Odawa Native Friendship Centre. "Home." Date Accessed: 20 February 2015: http://www.odawa.on.ca/home.html.

Office of the Superintendent of Financial Institutions. "About OSFI.” Last Modified 30 April 
2014: http://www.osfi-bsif.gc.ca/Eng/osfi-bsif/Pages/default.aspx.

Ontario Arts Council. "Christi Belcourt receives 2014 Ontario Arts Council Indigenous Arts Award.” News. Date Accessible 18 June 2014: http://www.arts.on.ca/Page5506.aspx.

Palmer, Bryan D. and David Frank, Todd McCallum and Jacques Rouillard. "Working-Class History," Historica Canada. Last Modified 16 December 2013: http://www.thecanadianencyclopedia.ca/en/article/working-class-history/.)

Centre for Indigenous Culture and Education (CACE). "Pîjashig! Welcome!" Date Accessed 01 February 2014: http://carleton.ca/aboriginal/.

The Professional Institute of the Public Service Alliance of Canada. "Work Force Adjustment Affected and Surplus Status." Date Accessed 20 June 2014: http://www.pipsc.ca/portal/page/portal/website/issues/wfa/faqs.

Tourand, Kenneth W. "Honouring a Cultural Community: Embracing Indigenous Values and Traditions in a Unionized Environment.” Master's Thesis, Simon Fraser University, 2000.

Public Service Commission of Canada. "History of Employment Equity in the Public Service and the Public Service Commission of Canada." Equity and Diversity Directorate. Released October 2011. Last Modified 25 October 2011: http://www.psc-cfp.gc.ca/plcy-pltq/eeadeeed/rprt/ee-psc-cfp/index-eng.htm.

Treasury Board of Canada Secretariat. "About the Treasury Board." Last Modified 19 December 2007: http://www.tbs-sct.gc.ca/tbs-sct/abu-ans/tb-ct/abu-ans-eng.asp.

Statistics Canada. “Archived Content: Community Highlights for Lac la Biche," Last Modified 26 August 2013: http://www12.statcan.ca/english/profil01/CP01/Details/Page.cfm?Lang=E\&Geo1=CSD\&C ode $1=4812035 \&$ Geo $2=$ PR \&Code $2=48 \&$ Data $=$ Count $\&$ SearchText $=1$ ac $\% 201 \mathrm{a} \% 20$ biche $\&$ Se $\operatorname{arch}$ Type $=$ Begins $\&$ SearchPR $=01 \& B 1=$ All $\&$ Custom $=$.

Canadian Museum of History. "The New Museum of History." Last Modified 17 October 2012: http://www.historymuseum.ca/media/news/the-new-canadian-museum-of-history/.

Canadian Museum of History. "The RBC Indigenous Training Program in Museum Practices." Date Accessed 30 November 2014: http://www.historymuseum.ca/research-andcollections/research/Indigenous-training-program/.

University Student Services: Indigenous Student Services Centre. “TYP Program Details.” Date Accessed 01 February 2014: http://www.aboriginalservices.ualberta.ca/. 


\section{Research Ethics Clearance Form}

\section{Carleton \\ U N I VER S ITY}

Canada's Capital University

Carleton University Research Office

Research Ethics Board

1325 Dunton Tower

1125 Colonel By Drive

Ottawa, ON K1S 5B6 Canada

Tel: $613-520-2517$

ethics@carleton.ca

\section{Ethics Clearance Form - Clearance Renewal}

This is to certify that the Carleton University Research Ethics Board has examined the application for ethical clearance. The REB found the research project to meet appropriate ethical standards as outlined in the Tri-Council Policy Statement: Ethical Conduct for Research Involving Human, 2nd edition, and the Carleton University Policies and Procedures for the Ethical Conduct of Research.

Original Date of Clearance: 16 August 2014

Renewal Date of Clearance: May 05, 2014

Researcher: Alisha Seguin (Student Research: Master's Student)

Department: Faculty of Arts and Social Sciences/History (Departmentof)

University: Carleton University

Research Supervisor (if applicable): John C. Walsh

Project Number: 13546

Alternate File Number (if applicable): 14-0437

Project Title: Remembering the Civil Service: A study of Aboriginal labour experiences in the post-war Ottawa Civil Service

Clearance Expires: May 31, 2015 


\section{All researchers are governed by the following conditions:}

Annual Status Report: You are required to submit an Annual Status Report to either renew clearance or close the file. Failure to submit the Annual Status Report will result in the immediate suspension of the project. Funded projects will have accounts suspended until the report is submitted and approved.

Changes to the project: Any changes to the project must be submitted to the Carleton University Research Ethics Board for approval. All changes must be approved prior to the continuance of the research.

Adverse events: Should a participant suffer adversely from their participation in the project you are required to report the matter to the Carleton University Research Ethics Board. You must submit a written record of the event and indicate what steps you have taken to resolve the situation.

Suspension or termination of clearance: Failure to conduct the research in accordance with the principles of the Tri-Council Policy Statement: Ethical Conduct for Research Involving Humans, 2nd edition and the Carleton University Policies and Procedures for the Ethical Conduct of Research may result in the suspension or termination of the research project.

\section{Andy Adler}

Chair, Carleton University Research Ethics Board

\section{Louise Heslop}

Vice-Chair, Carleton University Research EthicsBoard 


\section{Questions for Reflection}

\section{The Early Years: what led you to work for the civil service?}

- Where were you born?

- Have you moved during the course of your life?

- Where did you go to school? What did you study?

- What jobs have you held over the years?

\section{Bureaucracy: what are your experiences and memories within the federal civil service?}

- When/how were you hired for the Federal civil service? How long did you work for the civil service in Ottawa (or are you still employed?)

- Why choose to work there?

- How were you trained? Who taught you? What was the learning process like?

- What was most rewarding?

- What challenges have you faced, if any?

- What tasks were you assigned?

- Have you been hired into more than one position or department?

- Were you aware of positive or negative differences between yourself and others in regard to promotion?

- Were you satisfied with this employment?

- Were your wages acceptable to you?

- How conscious, if at all, were you of your Aboriginality while working for the Canadian civil service?

- Did your gender ever affect your employment in the civil service?

- Were you able to observe cultural or spiritual practices if you wished to during the period you worked in the civil service?

- Did you face any form of discrimination at work?

- Did you face benefits at work due to your aboriginality?

- Have you been an active union member?

- How closely, if at all, have you associated your position in the civil service with your identity as an individual?

- Has your position as a civil servant ever competed or been in tension with other aspects of what you feel your identity to be?

- Has working for the civil service impacted your social, cultural or family life in any way?

- What are your most positive memories of the civil service?

- Do you have any photographs, souvenirs or memorabilia that remind you of your employment with the civil service? What memories do you associate with each of these items? 
- Are there any other aspects of your experience in the civil service that you would like to discuss today?

Other questions:

How did you hear about the study?

Have you told your story before?

Why did you decide to participate?

When did you decide to share your story with me?

May I send a gesture of my thanks to you through the mail? 